\title{
AVALIAÇÃO IN VITRO DA CAPACIDADE DE SELAMENTO CORONÁRIO DE TRÊS MATERIAIS \\ USADOS COMO BARREIRA ADICIONAL, EM \\ DENTES TRATADOS ENDODONTICAMENTE, OBTURADOS COM DIFERENTES CIMENTOS ENDODÔNTICOS, UTILIZANDO O MÉTODO DE FILTRAÇÃO DE FLUÍDO.
}

\section{Cristiane M. de A. Nishiyama}

Dissertação apresentada à Faculdade de Odontologia de Bauru, da Universidade de São Paulo, como parte dos requisitos para obtenção do título de Mestre em Odontologia, Dentística - opção Materiais Dentários

Bauru 


\section{AVALIAÇÃO IN VITRO DA CAPACIDADE DE SELAMENTO CORONÁRIO DE TRÊS MATERIAIS \\ USADOS COMO BARREIRA ADICIONAL, EM DENTES TRATADOS ENDODONTICAMENTE, OBTURADOS COM DIFERENTES CIMENTOS \\ ENDODÔNTICOS, UTILIZANDO O MÉTODO DE FILTRAÇÃO DE FLUÍDO.}

Cristiane $\mathcal{M}$. de A. Nishiyama

Dissertação apresentada à Faculdade de Odontologia de Bauru, da Universidade de São Paulo, como parte dos requisitos para obtenção do título de Mestre em Odontologia, Dentística - opção Materiais Dentários

Orientador: Prof. Dr. Paulo Amarante de Araújo

Bauru

2007 


\section{Nishiyama, Cristiane Machado de Almeida}

N0633a Avaliação in vitro da capacidade de selamento coronário de três materiais usados como barreira adicional, em dentes tratados endodonticamente, obturados com diferentes cimentos endodônticos, utilizando o método de filtração de fluído / Cristiane Machado de Almeida Nishiyama -- Bauru, 2007.

p. 101: il. ; $30 \mathrm{~cm}$

Dissertação (Mestrado) -- Faculdade de Odontologia de Bauru. Universidade de São Paulo.

Autorizo, exclusivamente para fins acadêmicos e científicos a reprodução total ou parcial desta dissertação, por processos fotocopiadores e outros meios eletrônicos.

Assinatura do autor:

Data:

Comitê de ética e Pesquisa da FOB-USP

Protocolo n. 11/2006

Data:29/03/2006 


\title{
DADOS CURRICULARES
}

\author{
Cristiane M. de A. Nishiyama
}

Nascimento

01 de outubro de 1968

Filiação

Hélio Medeiros de Almeida

Zuleica da C. M. de Almeida

1987- 1991

Faculdade de Odontologia - UFBA

1992-1992

Aperfeiçoamento em Odontopediatria

PROFIS - São Paulo - Brasil

1992-1994

Estágio no Setor de Odontopediatria HRAC - USP- São Paulo - Brasil

1994-1996

Especialização em Residência em

Odontopediatria - HRAC- USP- São

Paulo- Brasil

1995-1995

Aperfeiçoamento em Endodontia

CECAE - São Paulo - Brasil

1998-2003

Cirurgiã- dentista do HRAC - USP- São

Paulo - Brasil

2003-2004

Atualização em Odontologia Estética CPO - São Paulo - Brasil 


\section{Dedico este trabalho}

Aos meus filhos, Bruno e Gabriel, por voçês tenho força, fé e um amor infinito....ser mãe é mais uma benção de Deus.... Aos meus pais, Hélio e Zuleica, por todo amor e dedicação, pelo exemplo de caráter e força, por terem me dado à vida, guiado meus passos e acreditado nos meus sonhos.....

Ao meu irmão Luis Paulo, exemplo de irmão e amigo, com quem posso contar em todos os momentos da minha vida..... Ao Kenji, muito obrigada, por toda paciência e apoio na confecção deste trabalho..... Á Deus, Por ser a razão de tudo.... Por ter por ter me dado à vida e colocado nela estas pessoas, sem as quais eu não chegaria aqui e nem seria o que sou....

“'Nunca, jamais........ se afaste dos seus sonhos, pois, se eles se forem, ainda assim você continuará vivendo.... mas, com certeza, terá deixado de existir." Charles Chaplin 
Ao Prof Dr. Paulo Afonso Silveira Franciscone, por ter me recebido e "aberto às portas" deste departamento, por seus ensinamentos e apóio durante este curso.

Ao Prof. Dr. Paulo Amarante de Araújo, pela orientação experiente e amiga durante a realização deste trabalho. Pelo senhor sinto grande admiração e respeito.

Ao Prof. Dr. Ricardo Marins de Carvalho, pelo carinho e apóio, pela sua disposição em ajudar e ensinar, para mim você é o exemplo de um mestre. Muito obrigada, pelas sugestões e idéias sem as quais, teria sido impossível a realização deste trabalho.

À Dafna, minha colega e amiga, por ter estado presente sempre, incentivando-me nos momentos difíceis e vibrando com as minhas vitórias durante esta jornada, sua contribuição e amizade foi muito importante na confecção deste trabalho.

À Fernanda Gomes de Moraes, pela disponibilidade em me ajudar na parte experimental, de forma simples e carinhosa.

A todos meus amigos e amigas, que de uma forma especial, sempre estiveram presentes na minha vida, saber que vocês existem, muitas vezes já é suficiente para me dar paz e força. 
Agradeço também,

À Faculdade de Odontologia de Bauru da Universidade de São Paulo, através de seu diretor Prof. Dr. Luis Fernando Pegoraro e ao presidente da comissão de Pós-graduação, Prof. Dr. Rafael Francisco Lia Mondelli.

Ao Prof. Dr. César Antunes de Freitas, pela sua dedicação e disponibilidade constante em ajudar.

Aos funcionários Departamento de Materiais Dentários, Alcides, Sandrinha e Lourisvalda, pelo carinho e amizade, sempre presentes e prestativos, nem que fosse com uma palavra de incentivo e apóio.

Aos meus colegas de pós-graduação, Fabiane, Márcia, Leandro, Breno e Ian, gostei muito de conhecê-los e de poder conviver com vocês durante este período, espero que nossa amizade esteja apenas no começo e que possamos continuar juntos no doutorado, sempre em busca de mais um sonho.

Ao Prof. Dr. José Pereira Lauris, pela dedicação ao realizar a análise estatística deste trabalho.

A CAPES, pelo apóio financeiro, fundamental para realização deste curso.

Aos funcionários do CIP, pela dedicação e ajuda na realização deste trabalho.

Aos funcionários da Biblioteca, pela atenção com que sempre me atenderam.

Às funcionárias da Pós-graduação, pela atenção e cordialidade. 


\section{SUMÁRIO}

LISTA DE FIGURAS...................................................................

LISTA DE TABELAS...................................................................

LISTA DE ABREVIATURAS E SÍMBOLOS ...........................................

RESUMO ..............................................................................

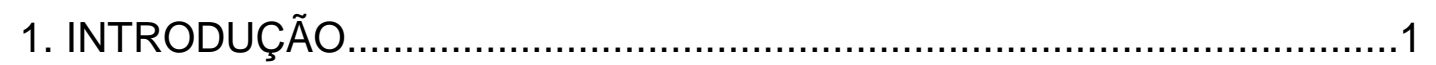

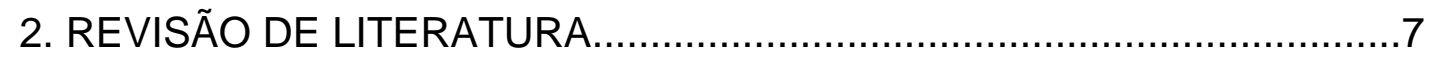

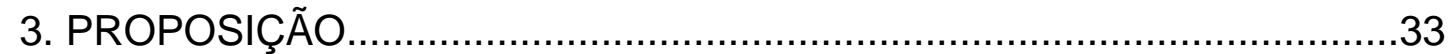

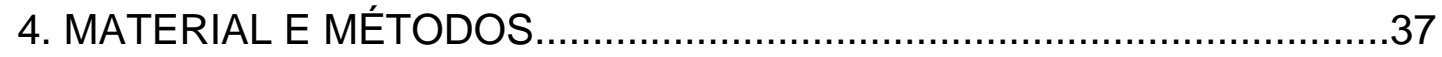

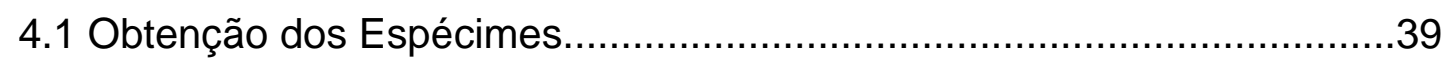

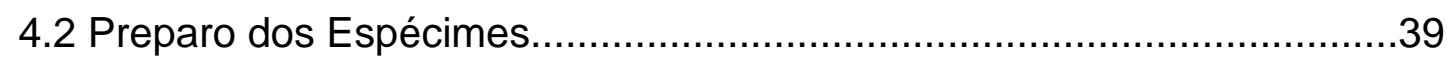

4.2 Método de filtração de fluído....................................................44

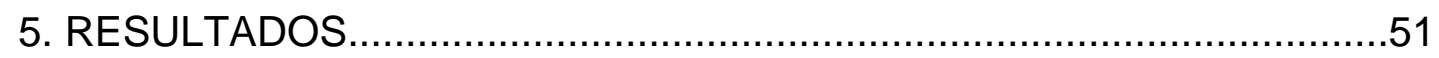

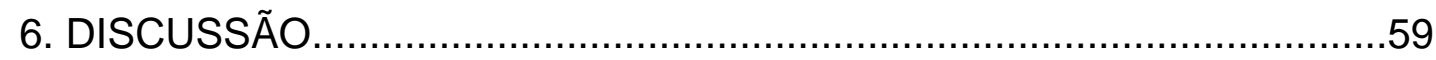

6.1 Discussão da metodologia empregada........................................64

6.2 Discussão dos Resultados................................................... 70

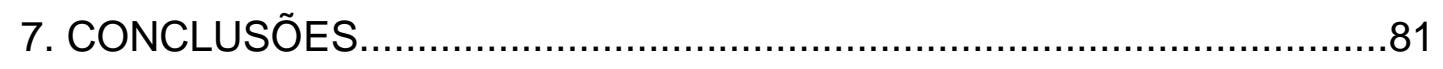

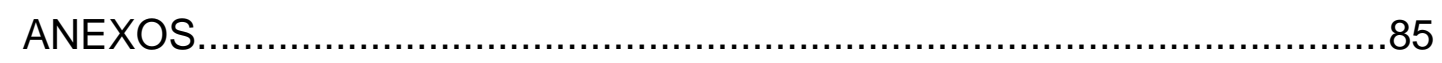

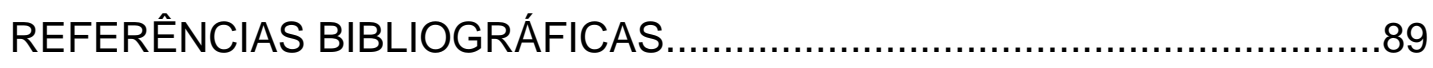

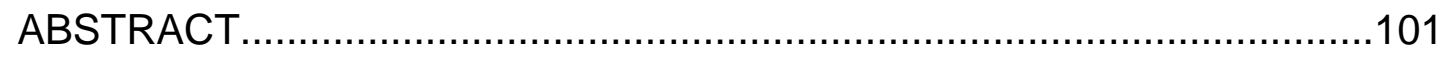




\section{LISTA DE FIGURAS}

Figura 1 - Fluxograma - preparo dos espécimes...... .39

Figura 2 - Sistema de filtração de fluídos 44

Figura 3 - Representação gráfica da interação entre cimentos e tempos estudados. .58 


\section{LISTA DE TABELAS}

Tabela 1 - Materiais testados. 49

Tabela 2 - Identificação das marcas, dos lotes e prazos de validade dos principais

materiais. .50

Tabela 3 - Valores médios da distância (em $\mathrm{mm}$ ) percorrida pela bolha de ar nos períodos de 15, 30 e 60 dias, e suas respectivas médias, no Grupo IA (Cimento $\mathrm{AH}$ Plus + Guta-percha e selamento com IRM). .53

Tabela 4 - Valores médios da distância (em $\mathrm{mm}$ ) percorrida pela bolha de ar nos períodos de 15, 30 e 60 dias, e suas respectivas médias, no Grupo IB (Cimento AH Plus + Guta-percha e selamento com sistema adesivo Adper Scothbond Multi Purpose Plus)...... .54

Tabela 5 - Valores médios da distância (em $\mathrm{mm}$ ) percorrida pela bolha de ar nos períodos de 15, 30 e 60 dias no Grupo IC (Cimento AH Plus + Guta-percha e selamento com sistema adesivo Adper Single Bond 2) .55

Tabela 6 - Valores médios da distância (em $\mathrm{mm}$ ) percorrida pela bolha de ar nos períodos de 15, 30 e 60 dias, e suas respectivas médias, no Grupo II (SistemaEpiphany) 56

Tabela 7 - Valores médios da distância (em $\mathrm{mm}$ ) percorrida pela bolha de ar nos períodos de 15, 30 e 60 dias nos Grupos IA, IB, IC e II .57 


\section{LISTA DE ABREVIATURAS E SÍMBOLOS}

mm - milímetro

cm - centímetro

$\mathrm{MPa}$ - mega pascal

$\mathrm{NaOCl}$ - hipoclorito de sódio

EDTA - ácido etileno diamino tetracético

min - minutos

s - segundos

h - hora

$\mathrm{n}$ - número

$\mathrm{V}$ - voltagem

$>$ - maior

$<-$ menor

civ - cimento de ionômero de vidro

psi - pressão por polegada quadrada

Kgf - quilograma-força

$\mathrm{KPa}$ - kilopascal

ANOVA - análise de variância

$\mu \mathrm{L}$ - microlitros

$\mu \mathrm{L} / \mathrm{min}$ - microlitros por minuto

$\mathrm{H}_{2} \mathrm{O}$ - água

rpm - rotações por minuto

$\mathrm{mL}$ - mililitros

SEM - microscopia eletrônica de varrredura

$\mathrm{pH}$ - potencial de hidrogenizacão

$\%$ - porcentagem

Ltda - limitada

p - significância estatística

${ }^{0} \mathrm{C}$ - grau Celsius

col - colaboradores 


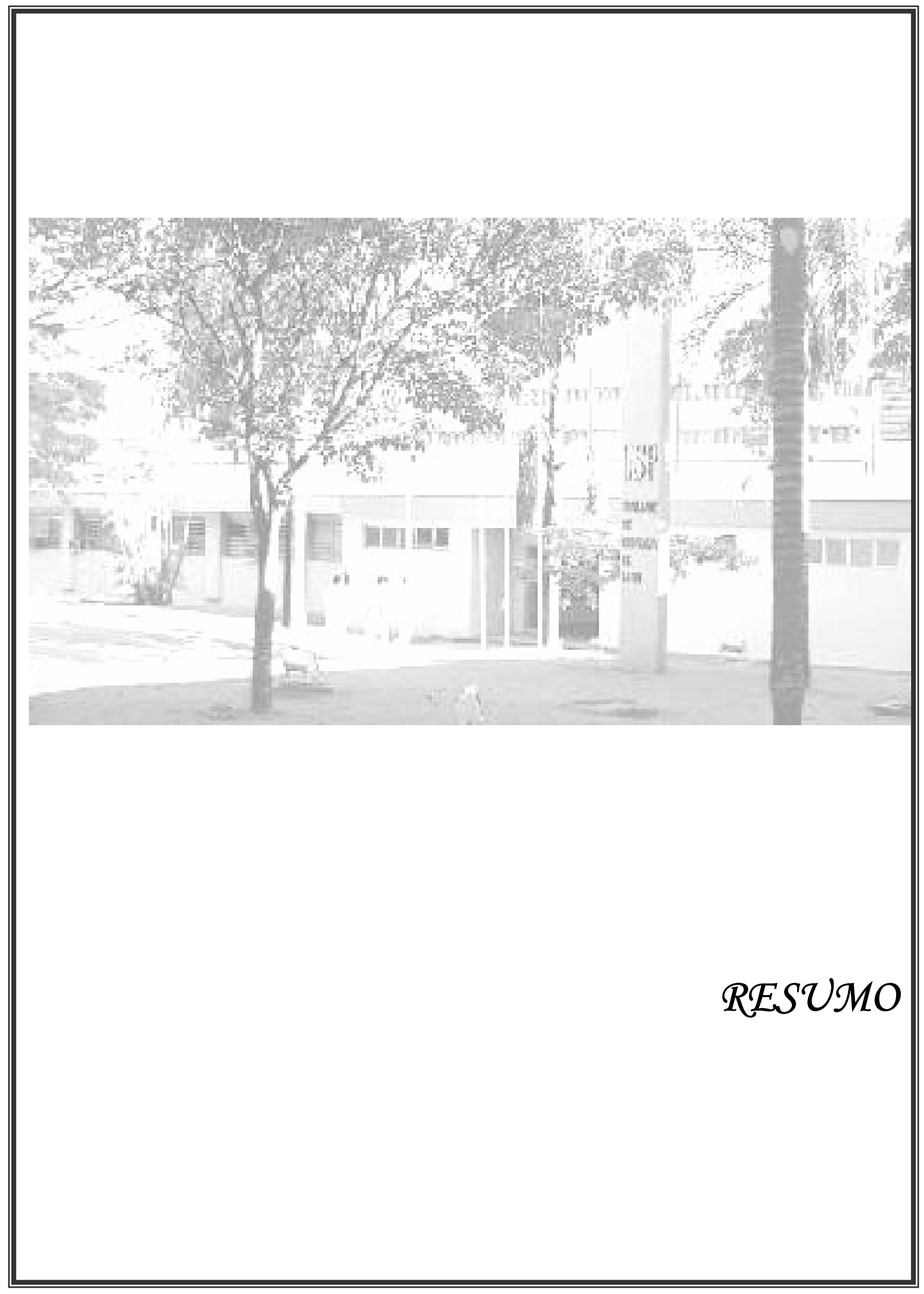




\section{RESUMO}

Grande parte dos insucessos dos tratamentos endodônticos ocorre por falha nas restaurações provisórias ou definitivas, em função da microinfiltração coroa-ápice. Sabe-se que, muitos pacientes realizam esse tratamento, mas não têm condições de restaurar o dente imediatamente, aumentando o risco de falhas nesse período intermediário, pela penetração de bactérias ou fluídos bucais até o canal radicular. Nos últimos anos, têm-se buscado, após o tratamento endodôntico, realizar o selamento intracoronário imediato, visando assim uma maior longevidade dessa terapia, até que se realize a restauração definitiva, ou até mesmo após esta. Diversas substâncias estão sendo testadas com o objetivo de avaliar essa penetração e existem diversos métodos disponíveis, para se avaliar a efetividade do selamento, como o de penetração de corantes e bactérias. Ultimamente, o método de filtração de fluído, que foi desenvolvido inicialmente para avaliar a permeabilidade dentinária, mas que posteriormente foi adaptado para uso em outras áreas, tem sido bastante utilizado para avaliar a microinfiltração em dentes tratados endodonticamente. Esse método é considerado quantitativo, não destrutivo, pela capacidade de se utilizar os mesmos espécimes em diferentes períodos de tempo, apresentando assim vantagens sobre os demais. Em função disso, o objetivo deste trabalho foi investigar, através do método de filtração de fluído, a permeabilidade de diferentes materiais utilizados no selamento intracoronário: o IRM, o Adper Scothbond Multi Purpose Plus e o Adper Single Bond 2, em dentes humanos unirradiculares obturados com cimento AH Plus e cones de guta percha, comparando-as entre si e também com a capacidade de selamento do novo sistema Epiphany, sendo as avaliações realizadas em períodos de 15, 30 e 60 dias. Após a aplicação do teste não paramétrico de Kruskall-Wallis e de Friedman, diferenças significantes foram encontradas entre os quatro grupos, sendo que o Grupo do IRM apresentou as maiores médias de filtrações em todos os períodos, e os grupos selados com os dois sistemas adesivos as menores. O sistema Epiphany apresentou médias iniciais baixas, mas sofreu um aumento significante dos seus valores de filtrações no último período, provavelmente por não ter recebido nenhum material selador secundário. Unitermos: microinfiltração; filtração de fluído; materiais seladores; endodontia 


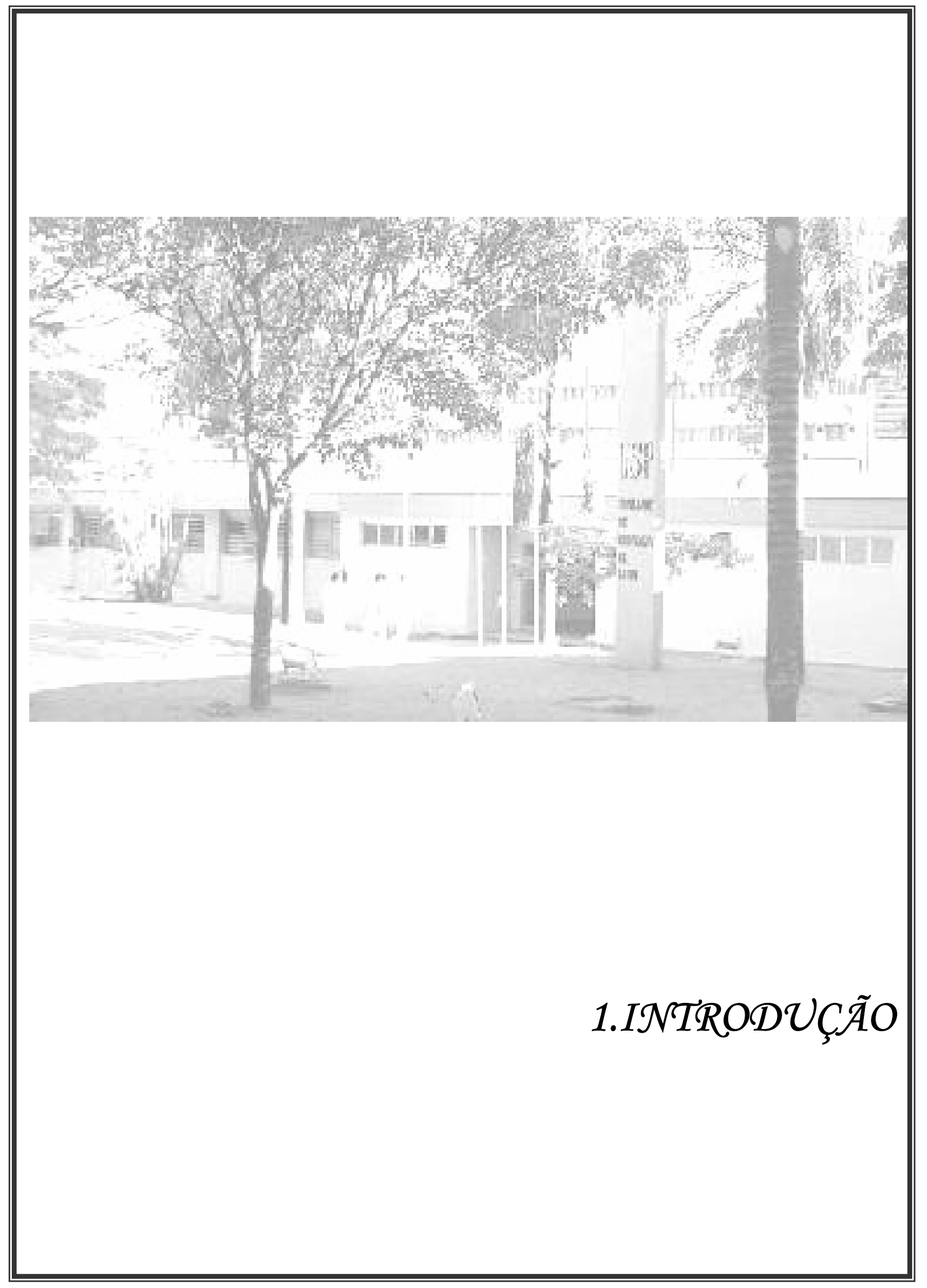




\section{1 - INTRODUÇÃO}

O tratamento endodôntico é um dos últimos recursos disponíveis para manutenção do dente no arco dentário, quando o mesmo teve sua vitalidade afetada de forma irreversível, não sendo possível mais a aplicação de tratamentos conservadores da polpa dental, bem como quando é evidente a necrose do tecido pulpar.

A obturação correta dos canais radiculares é considerada por muitos autores, como principal fator de sucesso desse tratamento, desde que, é claro, sejam respeitados todos os princípios básicos das fases anteriores ${ }^{20,23,25}$.

A presença de espaços vazios após uma obturação deficiente, atua como um verdadeiro meio de cultura, favorecendo a proliferação bacteriana, perpetuação de lesões periapicais e conseqüente insucesso do tratamento. $O$ espaço morto, ou seja, não preenchido por substâncias obturadoras nos canais, é a causa mais comum da persistência da inflamação periapical, e 60\% dos insucessos dos tratamentos endodônticos estão relacionados a canais mal obturados $^{23}$. Durante as décadas de 70, 80 e 90, a maioria dos estudos, voltaram-se para a adequada obturação do canal, ressaltando assim além das técnicas a importância das propriedades adesivas dos cimentos obturadores e da interação cimento/guta-percha/dentina, no sucesso do tratamento endodôntico. Portanto, pode-se observar que é de grande importância na endodontia, que nessa etapa final do tratamento, sejam empregadas técnicas e substâncias que promovam uma obturação o mais hermética possível desses canais, possuindo estas também, compatibilidade biológica com os tecidos periapicais.

Desta forma, a adesividade dos cimentos endodônticos à dentina, assim como a força de adesão desses à guta percha, também têm sido consideradas como um requisito importante para a tentativa da obtenção de canais hermeticamente obturados, ou seja, da adequada adaptação do material obturador as paredes do canal radicular ${ }^{65}$. Sabe-se entretanto, que a guta percha adere pobremente às paredes do canal radicular, e em função disso, existe uma busca, por técnicas obturadoras termomecânicas, que melhorem a adaptação dessa às paredes do canal radicular. Essa valorização das propriedades adesivas nos materiais obturadores, em busca de um adequado 
selamento, trouxe uma mudança no tradicional perfil de obturação dos canais radiculares, guta percha mais cimento obturador, com o surgimento de cimentos endodônticos a base de resina epóxica e mais recentemente a base de metacrilato, de dupla polimerização como Epiphany ${ }^{\mathrm{R}}$ Soft Resin Endodontic Obturation System (Pentron Clinical Technologies, Wallingford, CT, USA), usado em combinação com um primer e com o Resilon ${ }^{\mathrm{TM}}$; (Pentron Clinical Technologies, Wallingford, CT, USA), um cone obturador polimérico termoplástico, prometendo selamento coronário imediato proporcionado pela formação de um sistema monobloco, pois após a obturação do canal radicular, faz-se a polimerização com luz halógena do conjunto (cimento + cone resinoso), obtendo-se assim, segundo os fabricantes, uma barreira adicional contra a microinfiltração ${ }^{41}$. Esses novos materiais vêm tendo nos últimos anos, suas propriedades químicas e biológicas testadas, assim como sua capacidade de selamento coronário $3,5,55,65,38$.

Por outro lado, desde 1961, MARSHALL; MASSLER ${ }^{30}$ já haviam feito as primeiras referências, relacionando diretamente 0 prognóstico do comportamento de dentes com tratamento endodôntico, ao adequado selamento coronário e não só a obturação do canal. Assim, desde então, diversos estudos têm relacionado a qualidade desse tratamento e o seu sucesso a longo prazo, à qualidade do selamento da restauração coronária. Com esse enfoque, a infiltração coronária vem sendo também associada como responsável pelo insucesso de dentes tratados endodonticamente, principalmente a partir da década de 809,45,78,79.

Quando o canal obturado é exposto ao meio bucal por falha na restauração definitiva ou provisória, através de microinfiltrações, ou por perda dessas restaurações, haverá penetração de bactérias e suas toxinas, com provável insucesso do tratamento endodôntico, sendo indicado nesses casos, 0 retratamento $^{27,28,45}$. SWANSON; MADISON ${ }^{51}$, em 1987, encontraram em dentes com canais tratados, sem a colocação de uma restauração provisória, expostos a saliva artificial, por um período de 3 a 56 dias, uma contaminação de 79 a $85 \%$ dos canais radiculares. TORABINEJAD et al. ${ }^{62}$, em 1990 , constataram num estudo com 55 dentes obturados e não selados, que mais de $50 \%$ destes se apresentaram totalmente contaminados quando expostos ao microrganismo Staphylococcus epidermis num período de 19 dias, e que quando expostos a 
Proteus vulgaris, $50 \%$ destes se apresentaram também totalmente contaminados, só que num período de 42 dias.

Alguns autores afirmam também que, esse adequado selamento coronário, tem influência direta na saúde periapical dos dentes tratados endodônticamente, sendo mais importante que a qualidade técnica do tratamento endodôntico, já que se encontrou aumento significante de lesões periapicais, em dentes com canais tratados e selamentos inadequados, em relação aos adequadamente selados ${ }^{22,40,63}$. SHIPPER et al. ${ }^{49}$, em 2004 encontraram menor índice de inflamação periapical em dentes obturados com o Epiphany $^{R}$ Soft Resin Endodontic Obturation System e associaram ao melhor selamento coronário proporcionado por esse sistema.

Em função dessas observações, especial importância vem sendo atribuída nos últimos anos, ao selamento coronário imediato da câmara pulpar pós-tratamento, em que como um recurso adicional, têm-se feito a remoção de parte da guta percha e cimento obturador da entrada dos canais radiculares e a colocação de diversos materiais restauradores provisórios, definitivos resinosos, ionoméricos e sistemas adesivos, com o objetivo de evitar a

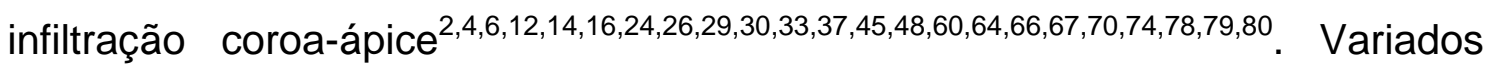
métodos têm sido utilizados para avaliar essa infiltração, como: testes de penetração e dissolução de corantes, corrente elétrica e o de transporte de fluídos.

O método de transporte de fluído, foi desenvolvido por DERKSON et al. ${ }^{15}$, em 1986, e tem sido usado extensivamente para avaliar in vitro, a eficiência de selamento de materiais restauradores e a quantificação da permeabilidade dentinária. Esse sistema consiste num circuito fechado de tubos capilares, preenchidos com água e ligados aos espécimes de teste, sendo que o transporte desse fluído, é medido pelo movimento de uma pequena bolha de ar, injetada no sistema utilizando-se uma pressão prédeterminada. Em 1993, WU et al. ${ }^{75}$, adaptaram esse método para utilização em pesquisas endodônticas, questionando a relevância de outros estudos de infiltração, e desde então, a qualidade do selamento apical e coronário das obturações dos canais radiculares e de materiais seladores provisórios, têm tido as suas permeabilidades testadas. Essa metodologia tem sido amplamente utilizada por muitos autores ${ }^{1,5,7,13,16,29,35,39,53,55,65,70,74,78,79,80}$ e desta forma, uma 
maior uniformização e confiabilidade na comparação dos trabalhos vem sendo conseguida. Por ser um método, quantitativo, longitudinal e não destrutivo, possibilita a reutilização da mesma amostra em diferentes períodos de tempo, facilitando o estudo em longo prazo e aumentando a confiabilidade dos resultados $^{9,15,39,45}$. Considerando todos esse aspectos, a proposta do presente estudo é avaliar in vitro a capacidade de selamento intracoronário, de dois sistemas adesivos e um material restaurador provisório, em canais radiculares obturados com um cimento endodôntico, a base de resina epóxica, sistema pasta-pasta, de polimerização química, usado em conjunto com a guta percha e de uso já consagrado; e essa mesma capacidade num cimento endodôntico a base de metacrilato, de polimerização dual, apresentado sob a forma de um sistema obturador composto de cone resinoso + cimento obturador, recentemente introduzido no mercado. 


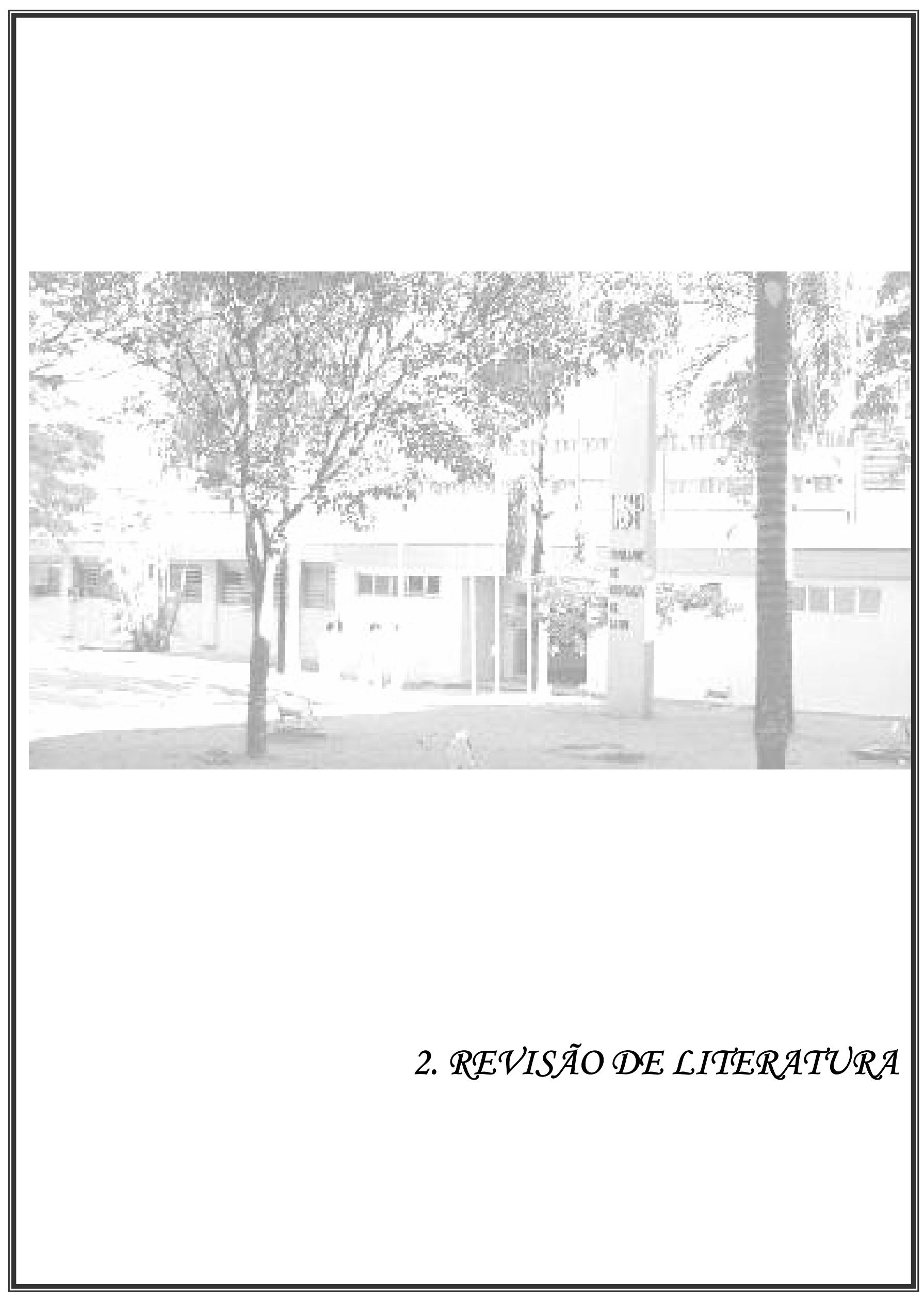




\section{2 - REVISÃO DE LITERATURA}

BLANEY et al. ${ }^{6}$, em 1981, avaliaram in vitro, a capacidade de selamento de dois materiais restauradores provisórios, o Cavit e o IRM, quando expostos ao microrganismo Proteus vulgaris, e colocados em contato com um curativo de paramonoclorofenol canforado (PMCC). Oitenta e seis molares humanos foram seccionados horizontalmente ao nível da câmara pulpar. Então, a face de esmalte da porção coronária de cada um foi condicionada por 2 min. com ácido fosfórico a 50\%, lavada, seca e incluída em num dispositivo de acrílico. Todos os espécimes foram esterilizados, em óxido etileno, colocados em seguida em contato com $30 \mathrm{ml}$ de solução estéril TSB acrescido de $0.1 \mathrm{~mL}$ de $P$ vulgaris. Em seguida, os espécimes foram novamente esterilizados, ficando incubados por 48 horas a $37^{\circ} \mathrm{C}$. Foi então feito um acesso oclusal, nessas porções coronárias e $3 \mathrm{~mm}$ de cada material, preparado de forma asséptica e de acordo com as instruções do fabricante, foi inserido nesses preparos, sendo que em seguida, 21 espécimes de cada material foram colocados em contato com 20 $\mu$ le PMCC a 35\%. Outros 21 espécimes controles, foram preparados da mesma forma, e colocados em contato com $20 \mu \mathrm{L}$ de solução salina estéril. Todos ficaram estocados por um período de três semanas. O IRM próximo ao PMCC promoveu, após três semanas, significantemente menos selamento que o IRM em solução salina ou o Cavit quando próximo ao PMCC. O Cavit colocado em solução salina promoveu o selamento menos eficiente. Os autores concluem que os dois materiais não promovem um selamento a prova da penetração do microrganismo $P$ vulgaris.

CHOHAYEB; BASSIOUNY ${ }^{12}$, em 1985, compararam a capacidade de selamento de três cimentos temporários; Cavit, óxido de zinco/eugenol e cimento de fosfato de zinco com a mesma propriedade, em duas resinas compostas; Adaptic, de polimerização química e Aurafill, fotopolimerizável. Um acesso cavitário foi realizado em 50 dentes humanos extraídos, livres de cáries. Os canais foram instrumentados, irrigados com hipoclorito de sódio a 2,5\% e secos. Dividiram-se então os espécimes em cinco grupos de dez, e colocou-se na câmara pulpar de cada um uma bolinha de algodão, deixando uma espessura mínima de $2,5 \mathrm{~mm}$ para colocação do material a ser testado. 
Vinte e quatro horas após, quatro camadas de verniz cosmético foram aplicadas, selando todas as faces, com exceção das margens, para posterior imersão em corante azul de metileno, a $4^{\circ} \mathrm{C}$, por 2 min., repetindo-se o procedimento por 40 vezes, antes da lavagem e secagem. Após o seccionamento longitudinal, avaliou-se a profundidade e intensidade da penetração do corante. O Cavit apresentou maior poder de vedamento das margens da restauração; seguido pelo Adaptic e Aurafill. O óxido de zinco eugenol e o fosfato de zinco apresentaram maiores valores de infiltração.

PASHLEY, et al. ${ }^{36}$, em 1988, realizaram um estudo visando avaliar as propriedades de selamento de quatro materiais: ZOE (óxido de zinco e eugenol), guta percha, Cavit-G e cimento de policarboxilato de zinco. Cavidades de Classe I foram preparadas em 66 dentes humanos, terceiros molares extraídos, que em seguida, tiveram suas porções coronárias removidas na junção amelocementária, para serem adaptados em plataformas de resina acrílica e posteriormente ao dispositivo de filtração de fluído. Após a confecção das cavidades, com 1 ou 2mm de profundidade, fez-se o ataque ácido, com ácido cítrico a 6\%, por 2 min., para permitir o máximo de permeabilidade da dentina. Utilizou-se uma pressão de 5 psi e foram feitas medições em intervalos de $1 \mathrm{~min}$. durante $5 \mathrm{~min}$.. Em seguida, os dois cimentos foram manipulados, nas seguintes proporções: de 1:1, na de 1 de pó para 2 de líquido, na de 1 de pó para 4 de líquido, na de 1 de pó para 6 ou 7 de líquido, e quando se utilizou a guta percha, esta foi aquecida previamente, para então serem introduzidas nas cavidades, sempre num tempo de trabalho de no máximo de $5 \mathrm{~min}$. As medições foram feitas $30 \mathrm{~min}$., $60 \mathrm{~min}$., 24 horas e 1 semana após a inserção dos materiais. Todos os espécimes sofreram ciclagem térmica e foram estocados em solução de $\mathrm{NaOCl}$ a 1\%. Foi possível concluir que, os diferentes proporcionamentos dos materiais resultaram em diferentes graus de selamento, sendo que o ZOE apresentou diferenças estatisticamente significantes nas diferentes proporções, e que o Cavit-G e o Durelon foram os que apresentaram melhores resultados de selamento.

ANDERSON, et al. ${ }^{2}$, em 1989, avaliaram in vitro a infiltração de três materiais restauradores temporários: Cavit, IRM e TERM, pelo método de filtração de fluído, em vários intervalos de tempos e após estresse térmico. Foram utilizados 30 dentes humanos, seccionados na junção amelo- 
cementária, em que foram preparadas cavidades nas porções coronárias. Em seguida, os espécimes foram adaptados em plataformas de resina acrílica, com adesivo a base de cianocrilato. Três grupos de dez foram formados e restaurados, e a microinfiltração medida sob uma pressão de 20 psi, após 1 h., 24 h., 7 dias, e após o estresse térmico. Entre os testes, os espécimes foram mantidos em solução de Ringer`s, contendo $0,2 \%$ de sódio ácido (agente antimicrobiano), a $37^{\circ} \mathrm{C}$. Os resultados indicaram o TERM como material que promoveu melhor selamento e estatisticamente superior ao Cavit e IRM. O IRM apresentou significante maior infiltração após estresse térmico e o Cavit não foi considerado clinicamente aceitável, por apresentar fraturas, expansão e extrusão do material da cavidade, fatos que não ocorreram nos demais espécimes.

BOBOTIS, et al. ${ }^{7}$, no mesmo ano, num estudo in vitro, utilizando o método de filtração de fluído, avaliaram as propriedades de selamento dos seguintes materiais: Cavit, Cavit-G, IRM, TERM (cimento fosfato de zinco), Fuji II (civ), Durelon (cimento de policarboxilato). Utilizaram-se 70 dentes humanos, incisivos, caninos e pré-molares, cortados na junção amelocementária, removendo-se o tecido pulpar coronário, e então essa porção coronária adaptada a plataformas de resina acrílica após a colocação dos referidos materiais. Cada material foi manipulado de acordo com as instruções do fabricante, com exceção do IRM, que foi manipulado numa proporção de $2 \mathrm{~g} / \mathrm{mL}$. Os espécimes foram conectados ao dispositivo de filtração, numa pressão de 20 psi, medindo-se a infiltração de 1 em 1 min. por 4 min., em diferentes tempos: 15 min. após a colocação, 1 h., 24 h. e 1 sem. após, ficando estocados nesse período em solução de Ringer’s a $37^{\circ} \mathrm{C}$. Após 1 semana os espécimes sofreram ciclagem térmica, e então eram reavaliadas as infiltrações até que todos os 10 dentes de cada grupo demonstrassem infiltrações. Os materiais Cavit, Cavit-G, TERM, cimento de ionômero de vidro, mostraram-se a prova de infiltrações até o período de 8 semanas, e o IRM e cimento de policarboxilato, apresentaram-se menos efetivos que os demais, sendo mais influenciados pelos efeitos da ciclagem térmica.

TURNER et al. ${ }^{66}$, em 1990, avaliaram in vitro, a microinfiltração de sete materiais restauradores temporários, colocados sobre acessos endodônticos e restaurados com amálgama. Setenta molares humanos foram 
seccionados na junção amelocementária. Inicialmente, preparos cavitários de classe I, foram realizados e então os dentes restaurados com amálgama, sendo aplicadas antes, duas camadas de verniz Copalite e em seguida, mantidos em solução de Ringer`s, com 0,2\% de sódio ácido, por 1 sem. Os espécimes foram então acoplados, individualmente, a placas de resinas e ao dispositivo de filtração de fluído, numa pressão de 20 psi, de modo que se mediu a primeira microinfiltração. Após essa etapa, realizaram-se acessos coronários nas restaurações de amálgama, e os espécimes foram divididos em grupos de dez, de acordo com o material restaurador temporário colocado nesse preparo, Cavit e Cavit G; IRM; Durelon - cimento policarboxilato de zinco; TERM; cimento fosfato de zinco e Fuji II - cimento de ionômero de vidro, sempre numa espessura aproximada de $4 \mathrm{~mm}$. Os espécimes foram imediatamente recolocados na mesma solução anterior e incubados a $37^{\circ} \mathrm{C}$, até que as novas medidas de microinfiltrações feitas $15 \min , 1 \mathrm{~h}, 24 \mathrm{~h}, 1$ semana e 2 semanas, no mesmo dispositivo e sob as mesmas condições da anterior. O Cavit, Cavit G, TERM, IRM e o Fuji II apresentaram excelente selamento, não havendo diferenças estatisticamente significantes entre eles e os valores do grupo controle, ou seja, das restaurações de amálgama; enquanto que o Durelon e o cimento de fosfato de zinco, apresentaram altos valores de microinfiltração.

LIM $^{26}$, em 1990, comparou a capacidade de selamento do Ketac Fil, civ, com dois materiais seladores temporários, o Cavit-W, e o Kalzinol, um cimento a base de óxido de zinco reforçado. Molares humanos com raízes fusionadas, extraídos, tiveram o acesso coronário realizado e a metade apical das raízes removidas. Após limpeza com ultra-som, os acessos foram alargados $2,5 \mathrm{~mm}$ e os dentes foram estocados em água destilada até a obturação. Cada grupo contendo dez dentes, foi obturado de acordo com o material selador aplicado, sempre na espessura de $3,5 \mathrm{~mm}$ manipulados e inseridos de acordo com instruções do fabricante, com exceção do Ketac-Fil que possuiu um grupo onde não se realizou o condicionamento da dentina com ácido poliacrílico. No controle positivo usou-se guta percha, e no negativo nenhuma cavidade oclusal foi realizada. Os espécimes foram protegidos com uma camada de selante de silicone (Silicone RIV) em toda superfície externa, imersos em solução de cloreto de potássio a $1 \%$, a $37^{\circ} \mathrm{C}$, conectados a um 
cátodo, estabilizado numa corrente de $10 \mathrm{~V}$, por 30 dias, para realização do teste eletroquímico. O grupo do Ketac-Fil com condicionamento infiltrou menos, seguido do Kalzinol, do Ketac-fil sem condicionamento e por fim o Cavit-W. Não se encontrou diferença significante de infiltração apenas entre os grupos do Ketac-Fil, sendo encontrada uma alta diferença entre os demais grupos.

SAUNDERS; SAUNDERS ${ }^{46}$, ainda em 1990, realizaram um estudo in vitro, em 69 molares humanos, visando avaliar a infiltração de três materiais restauradores (Sybraloy- amálgama; Ketac Bond- civ e Ketac Silver- civ reforçado com partículas de prata - cermet) colocados na câmara pulpar de dentes tratados endodonticamente e obturados com guta percha e Tubliseal, pela técnica da condensação lateral, sendo que a porção coronária foi também preenchida com esses materiais e o acesso coronário preenchido com Cavit e estocados em água deionizada a $37^{\circ} \mathrm{C}$, por 1 mês. Em seguida, os dentes foram divididos em 3 grupos de 15 dentes, e um de 9, que foi usado com controle positivo. O Cavit foi então removido de todos os dentes, e nos 4 grupos de 15, a guta percha e o cimento obturador foram também removidos da porção coronária, sendo então os materiais restauradores colocados. No grupo controle a câmara não foi selada e no grupo de 9 dentes manteve-se a guta percha e o cimento. Após a colocação dos materiais, os grupos foram mantidos por 60 dias em água deionizada com timol a 0,1\%, a $37^{\circ} \mathrm{C}$. Antes da imersão em corante Índia Ink, por 48 h. a $37^{\circ} \mathrm{C}$, e da ciclagem térmica, fez-se o selamento dos ápices com um cimento a base de cianoacrilato. Duas camadas de verniz cosmético foram aplicadas no acesso coronário. Após lavagem e secagem, os espécimes foram desmineralizados, por aproximadamente 72 horas, limpos, estocados e examinados em estereomicroscópio (6x de aumento). Diferenças estatisticamentes significantes foram encontradas somente entre o grupo com guta percha e os demais com os materiais restauradores, que entre si não apresentaram diferenças significantes na infiltração. O grupo controle positivo não foi incluído na análise. No grupo com guta percha, encontrou-se infiltração até o nível da furca e dentro do canal radicular.

WU et al. ${ }^{75}$, em 1993, visaram avaliar um novo modelo de transporte de água, desenvolvido por DERKSON e col. ${ }^{15}$ (1986) e adaptado para estudos de infiltração em canais obturados, e compará-lo a passagens de bactérias ao 
longo desses canais obturados. O modelo foi submetido a uma pressão de 120 $\mathrm{KPa}$, a água contida nos capilares tinha uma temperatura de $20^{\circ} \mathrm{C}$, e $\mathrm{O}$ procedimento foi repetido 10 vezes para cada teste. Sessenta e dois caninos humanos, extraídos, com comprimento radicular padronizado em 10mm, foram instrumentados a $1 \mathrm{~mm}$ do ápice, até a lima 70 , irrigados com $\mathrm{NaOCl}$ a $2 \%$. Dois dentes não foram obturados e permaneceram como controle positivo, e duas peças de vidro de $10 \mathrm{~mm} \times 4 \mathrm{~mm}$, foram usadas como negativo. Os outros 60 espécimes foram divididos em dois grupos de 30. Os do grupo I, e os quatro dos controles, foram estocados numa infusão de BHI e autoclavados, para obtenção e manutenção da assepsia. Em seguida, foram lavados com $5 \mathrm{ml}$ de $\mathrm{NaOCl}$ a $2 \%$ e secos, e obturados com $\mathrm{AH}-26$ e guta percha, pela técnica da condensação lateral. As superfícies radiculares foram então cobertas por duas camadas de esmalte cosmético, exceto na região do ápice e ao redor do acesso coronário. Todos os espécimes foram então, acoplados a dois tubos plásticos. Na porção apical continham caldo BHI e na coronária, uma suspensão contendo bactérias (pseudomonas aeruginosas), e foram estocagem em estufa a $37^{\circ} \mathrm{C}$, por 2 sem. Nesse período só um espécime, do grupo II, obteve turvação do caldo, sinal de contaminação, e após 50 dias, os outros espécimes tiveram seus caldos avaliados e sua turvação mensurada. Os espécimes do grupo II foram obturados conforme o grupo I, mantidos em estufa por $48 \mathrm{~h}$ para o teste de filtração de fluído, onde cada espécime foi avaliado em três intervalos de tempo. Obtiveram-se os seguintes resultados: após 50 dias, dois espécimes mostraram penetração de bactérias na porção apical; 39 espécimes foram classificados com escasso volume de bactérias, $14 \mathrm{com}$ poucas e 7 com muitas bactérias. A passagem de bactérias no teste prévio, não teve influência significante nas raízes que foram testadas posteriormente pelo método de filtração de fluído. E, finalmente que houve passagem de fluído pelos condutos obturados, mas que não houve passagem de bactérias.

PISANO, et al. ${ }^{37}$, no mesmo ano, avaliaram in vitro as propriedades dos materiais Cavit, IRM e do Super- EBA, aplicados como seladores na entrada dos canais radiculares, visando a prevenção da microinfiltração de saliva e seus componentes, após o tratamento endodôntico e na ausência da restauração coronária. Setenta e quatro dentes, livres de fraturas ou defeitos, foram instrumentados a $1 \mathrm{~mm}$ do ápice, irrigados com $\mathrm{NaOCl}$ a $5,25 \%$, secos e 
obturados pela técnica da condensação lateral com guta percha e cimento Roth`s 801. Em seguida 3,5 mm de material obturador foi removido abaixo da junção amelo-cementária, sendo o excesso de cimento limpo da porção coronária e os espécimes mantidos em estufa, a $37^{\circ} \mathrm{C}$, por 72 horas, para secagem do cimento. Em seguida, dividiram-se os espécimes em três grupos $(n=20)$, de acordo com o material selador aplicado e removeram-se os excessos. Dez dentes não receberam nenhum material selador; cinco dentes formaram o controle positivo e cinco o negativo. Um modelo experimental foi usado para avaliar a penetração de bactérias, que era avaliada pelo índice de turvação do caldo, resultante do crescimento bacteriano, onde os espécimes estavam imersos. Após 90 dias, observou-se que no grupo do Cavit, 15\% dos espécimes infiltraram, no do IRM e no do Super-EBA, 35\%. Os autores concluem que esse selamento adicional, pôde ajudar a prevenir ou minimizar o risco de infiltração, durante e após, o tratamento endodôntico, até a restauração definitiva ser realizada.

Com o objetivo de testar in vitro, a capacidade de selamento de dentes restaurados com três sistemas adesivos dentinários e uma resina composta, YOUGSON et al. ${ }^{78}$, em 1999, utilizaram dois métodos: o de filtração de fluído e o de silver trace, numa mesma amostra, sob o efeito ou não da termociclagem, comparando-os. Trinta porções coronárias de dentes prémolares, humanos, foram preparadas com pequenas cavidades de classe II, divididas em três grupos e restauradas da seguinte forma: grupo I, lavagem com ácido poliacrílico a 20\%, aplicação do Fuji Bond LC, numa fina camada; grupo II, ácido fosfórico a 37\%, Scothbond Multi-Purpose Plus + resina composta (Pekafill NF); grupo III, ácido fosfórico 37\%, Primer\&Bond $2.1+$ resina composta (Pekafill NF). Todos os materiais foram polimerizados e testados pelo método de filtração de fluído após 2 h, 24 h, 1 sem e 1 mês, numa pressão de $0.069 \mathrm{MPa}$. Após, fez-se precipitação com prata, dissolução com ácido nítrico e observação da infiltração. Seis espécimes de cada grupo foram submetidos a termociclagem após uma semana. Nenhuma diferença significante de infiltração foi encontrada, entre os materiais. A termociclagem também não produziu diferenças significantes entre os grupos. Onde houve infiltração de prata, foi indicada falha no selamento das cavidades. O método de filtração de fluído foi considerado, entretanto, mais sensível, porém, sem 
diferenças estatisticamente significantes com os resultados obtidos do outro método, sendo utilizado numa pressão de 0.069 MPA. Os autores acreditam que esse resultado se deve a grande variabilidade inerente aos dentes e o tamanho da amostra ser relativamente pequeno.

DAVALOU et al. ${ }^{14}$, em 1999, se propuseram, a avaliar a capacidade de selamento coronário de dois materiais adesivos colocados imediatamente após a obturação dos canais radiculares. Oitenta dentes unirradiculares humanos, foram instrumentados com Profile, irrigados com $\mathrm{NaOCl}$ a 5,25\% e EDTA à 17\%, secos e obturados com cimento EWT e guta percha. Dois grupos foram então formados; no primeiro $(n=37)$ fez-se ataque ácido, por 30 segundos, no acesso cavitário de cada dente, e aplicação dos adesivos Tenure A e B em todas as paredes da câmara pulpar e no acesso, e então, porções iguais da pasta Core, foram misturadas e colocadas dentro da câmara. No segundo, após ataque ácido, e utilização dos adesivos, aplicou-se a pasta resinosa Panavia 21 na superfície dentária, compactou-se amálgama na câmara pulpar, e finalmente Oxyguard II nas margens da restauração por 3 min. Partiu-se então para avaliação da infiltração, após proteção com verniz, imersão em corante Índia Ink por 10 dias, desmineralização em ácido cítrico, e avaliação em estereomicroscópio. Os dois grupos apresentaram bons resultados de selamento, sem diferenças significantes entre si, porém os autores sugerem mais estudos em longo prazo, para que se possam extrapolar os resultados para a clínica.

URANGA et al. $^{67}$, em 1999, compararam, in vitro, a habilidade de selamento do acesso cavitário, de quatro materiais: Fermit, Cavit, Dyract e Tetric. Noventa dentes unirradiculares, extraídos, não restaurados, tiveram seus canais instrumentados, obturados pela técnica da condensação vertical com guta percha aquecida mais cimento AH Plus, que teve então, seu excesso removido mantendo uma profundidade de $4 \mathrm{~mm}$ da margem do ângulo cavo superficial, para colocação do material selador. Quatro grupos de 20 dentes foram formados de acordo com o material selador aplicado. No grupo do Dyract, fez-se condicionamento prévio com ácido ortofosfórico. Cinco dentes fizeram parte do grupo controle positivo, onde não se aplicou nenhum material, e no negativo, mais cinco, tiveram toda sua extensão coberta com esmalte cosmético. Realizou-se então a termociclagem (100 ciclos, variando a 
temperatura de 0 a $55^{\circ} \mathrm{C}$ ). Todos os espécimes foram cobertos com três camadas de esmalte cosmético, com exceção da região selada, imersos em solução de azul de metileno, e novamente submetidos à ciclagem. Após lavagem, secagem e seccionamento, observaram-se os variados graus de infiltração através de microscopia (aumento de 10x). Os cimentos temporários (Cavit e Fermti), sofreram infiltração estatisticamente maior que os materiais restauradores, exceto entre o Dyract e Tetric. Os autores consideraram fundamental, portanto, a escolha adequada do material selador para o sucesso do tratamento endodôntico.

No ano de 2001, BELLI et al. ${ }^{4}$, realizaram um estudo visando avaliar, de forma quantitativa, através do método de filtração de fluído, a habilidade de selamento intracoronário de quatro diferentes materiais, colocados nas cavidades coronárias imediatamente após o tratamento endodôntico, usados com o objetivo de evitar a infiltração coronária. Utilizaram-se 40 molares humanos, extraídos, em que a porção coronária e parte da raiz, $2 \mathrm{~mm}$ abaixo da região de furca, foram removidas com um disco adiamantado. Após a instrumentação manual e obturação dos canais com cone principal de guta percha, sem cimento, realizou-se a limpeza da câmara pulpar com $\mathrm{NaOCl}$ à 5\% por cinco min. e lavagem final com água aquecida por 2 min. Os espécimes foram divididos, de forma aleatória, em quatro grupos, de acordo com o material que seria usado na câmara pulpar: grupo I- C\&B Metabond + pó transparente de polimetilmetacrilato; grupo II- sistema adesivo One-Step + resina microhíbrida de baixa viscosidade (Aelite Flo); grupo III- Clearfill SE Bond Primer + resina composta fotopolimerizável transparente (Palfique) e grupo IV- IRM. Todos os materiais foram manipulados de acordo com as instruções do fabricante, as cavidades preenchidas, e então os espécimes adaptados, de forma invertida, em peças de Plexiglass de $2 \mathrm{~cm} \times 0,7 \mathrm{~cm}$, que tinham um orifício de gauge 18, onde era acoplado o dispositivo de filtração de fluído. Após a aplicação dos seladores a guta percha usada nos condutos foi removida, e essa região preenchida com água. Utilizou-se uma pressão de $20,7 \mathrm{KPa}$ ou $211 \mathrm{~cm} / \mathrm{H}_{2} \mathrm{O}$ de água, e fizeram-se as medições de $2 \mathrm{em} 2 \mathrm{~min}$, por 8 min. Mediu-se a qualidade de selamento após 1 dia, 1 sem e 1 mês. O IRM apresentou significantemente mais infiltração que os adesivos e após 1 mês, os três sistemas adesivos mostraram um excelente selamento, podendo ser 
considerados segundo os autores, como um selamento secundário na prevenção da infiltração intracoronária. Os autores ressaltaram, entretanto, que esses adesivos não foram submetidos a nenhum esforço, e que no uso clínico devem ser protegidos por materiais como amálgama, resina composta ou civ.

POMMEL; CAMPS ${ }^{39}$, no mesmo ano de 2001, realizaram um estudo com objetivo de avaliar a influência da pressão e do tempo no método de filtração de fluído. Esse método foi introduzido na literatura por Derkson e colaboradores, e tem sido bastante usado em trabalhos para avaliar a infiltração apical e coronária de dentes tratados endodonticamente, a eficiência de materiais obturadores retrógrados e restauradores temporários. Os resultados são expressos em $\mu \mathrm{L} / \mathrm{min}$, ou seja, quanto de água infiltrou, num determinado período de tempo, porém esse resultado depende da pressão que se coloca no sistema e do tempo usado na avaliação, entretanto, não existe uma padronização dessas unidades, daí a importância desse estudo. Os autores utilizaram incisivos centrais superiores, cujas coroas foram cortadas na junção cemento-esmalte, os canais instrumentados com sistema ProFile e obturados com Thermafil e cimento Sealite (à base de óxido de zinco eugenol), e então estocados por $24 \mathrm{~h}$ a $37^{\circ} \mathrm{C}$ para secagem do cimento. As 36 raízes foram divididas em dois grupos, 18 testados com pressão de $15 \mathrm{~cm} / \mathrm{H}_{2} \mathrm{O}$; e 18 com pressão de $150 \mathrm{~cm} / \mathrm{H}_{2} \mathrm{O}$. As raízes foram inseridas em um tubo de silicone, e conectadas a um capilar de $0,7 \mathrm{~mm}$ de diâmetro, preenchido com uma solução salina tamponada + penicilina + estreptomicina + fungicida. $A$ leitura dos espécimes foi realizada com o auxílio de um computador gráfico, e realizada em intervalos de tempo de dois min, $1 \mathrm{~h}$ e $24 \mathrm{~h}$. Nesse período os espécimes ficaram estocados em água. Os resultados foram submetidos ao Teste de Duncan, e nenhuma interação estatística foi encontrada entre os dois fatores, tanto uma baixa pressão, como uma alta, deram valores de infiltração altos. Uma diferença estatisticamente significante foi obtida nos três períodos de tempo. De acordo com esses resultados, a quantidade de filtração diminui com o aumento do tempo, mas universalmente, uma alta filtração foi encontrada com o aumento da pressão. Deve-se considerar o diâmetro do tubo, tamanho da bolha, mensuração do tempo e pressão aplicada, como fatores importantes e concluíram que é necessária a padronização do método e dos resultados, para se possa comparar os diversos estudos na literatura. 
WOLANEK et al. ${ }^{74}$, no ano de 2001, testaram in vitro, a efetividade de um agente adesivo dentinário (Clearfill Liner Bond 2V) usado como barreira coronária. Cinquenta e um molares humanos extraídos tiveram a metade das raízes removidas, o acesso endodôntico realizado, formam instrumentados com Profile GT e irrigados com hipoclorito de sódio a 5,25\%. Então, dividiramse os espécimes em dois grupos, um com 21 dentes que foram obturados com guta percha, sem cimento, pelo sistema Obtura II, e nos outros 30, adicionouse o cimento da Kerr - EWT, a base de óxido de zinco e eugenol. Em seguida, as câmaras pulpares foram limpas com clorofórmio e secas. Novamente três grupos foram formados, de quinze dentes cada, da seguinte forma: grupos I- 15 (obturados somente com guta percha) e II- 15 (com guta percha e cimento) receberam o agente adesivo; e no grupo III- nos outros 15, com guta percha e cimento, não se colocou nada. No grupo controle positivo, três dentes sem cimento e sem barreira; e no negativo, três dentes sem cimento, mas com barreira de duas camadas de verniz na câmara pulpar. A infiltração foi testada usando-se um modelo de teste com streptococcus mutans, sendo avaliada por 30, 60 e 90 dias. Após análise de Fisher's, observaram-se os seguintes resultados: grupo I e II não exibiram infiltração bacteriana, onze espécimes do grupo III, infiltraram entre o $15^{\circ}$ e $76^{0}$ dias. A barreira coronária, nos grupos I e II, foi significantemente mais efetiva até o $60^{\circ}$ dia.

WELLS et al. $^{70}$, em 2002, avaliaram a eficácia de selamento coronário de barreiras com dois materiais: o Principle e o cimento resinoso C\&B Metabond, realizadas com 2mm de espessura colocadas sobre a câmara pulpar ou dentro (na entrada) dos canais radiculares, visando observar se haveria diferença na eficácia do selamento, pela localização dessa barreira e pelo material. Sessenta e dois molares inferiores humanos extraídos, armazenados em solução salina, tiveram suas coroas removidas, deixando 5 $\mathrm{mm}$ delas acima da junção cemento-esmalte, e $5 \mathrm{~mm}$ de raiz após a região da furca. O tecido pulpar foi removido, os canais alargados com brocas GatesGlidden $\mathrm{n}^{-} \mathbf{3}$, irrigados com água, secos e obturados, com cones de guta percha no 90, selando o ápice e a porção coronária. A partir daí, os dentes foram divididos em 4 grupos de 15, e dois controles de um dente cada. No grupo I, 2 $\mathrm{mm}$ de Principle foram aplicado na entrada da câmara, e no grupo II, a $2 \mathrm{~mm}$ do orifício do canal, na mesma espessura. Nos grupo III e IV da mesma forma, 
só que com C\&B Metabond. No grupo controle positivo, não se colocou guta percha nem barreira, e no negativo, apenas guta percha, e duas camadas de verniz cosmético foram aplicadas no assoalho da câmara. O método usado foi o de filtração de fluído, numa pressão de $20 \mathrm{~cm} / \mathrm{H}_{2} \mathrm{O}$, e as avaliações feitas após 1 h,1 sem, 2 sem e 4 sem. Os autores observaram que, a localização da barreira não interfere nos resultados, mas diferenças significantes foram encontradas nos materiais. O Principle infiltrou significantemente mais que o C\&B Metabond na 1 hora, mas o selamento aumentou com o tempo, já o C\&B Metabond infiltrou menos no início, mas essa infiltração aumentou após 4 sem. Principle foi mais fácil de ser usado assim como o selamento na entrada da câmara. Segundo os autores, compômeros são materiais bem indicados para barreira coronária, por não precisarem de primers nem de agentes adesivos, promovendo adesão ao tecido dentário e podendo ser químicos ou auto polimerizáveis.

ZAIA et al. ${ }^{79}$, em 2002, ao considerarem a importância da infiltração via coronária, após o tratamento endodôntico, tiveram como objetivo, avaliar in vitro a capacidade de selamento coronário do IRM, Coltosol, Vidrion R e do Scoth Bond. Cem molares inferiores, humanos, extraídos tiveram seus canais instrumentados, a $1 \mathrm{~mm}$ do ápice, pela técnica híbrida, com limas e brocas Gates-Glidden, e irrigados com $\mathrm{NaOCl}$ a 5,25\%, EDTA a 17\% e novamente com NaOCl. Após secos e obturados com guta percha e cimento Endométhasone, pela técnica da condensação lateral, foram divididos em 4 grupos, segundo o material selador a ser usado, e um grupo controle positivo, onde não se usou material selador. Dois milímetros de cada material foram aplicados para selar o acesso aos canais radiculares. No caso do Scoth Bond, cada duas gotas de adesivo proporciona, aproximadamente $2 \mathrm{~mm}$ de espessura, e mesmo clinicamente não sendo padrão, quando era necessário, usava-se mais uma gota, com o objetivo de padronizar a barreira. Após armazenagem em estufa, a $37^{\circ}$ e 100\% de umidade realtiva, por 7 dias, as raízes foram seladas com esmalte de unha vermelho, com exceção da região coronária, e foram imersas em corante Índia, por 5 dias, lavadas e descalcificadas em ácido hidroclorídrico por $72 \mathrm{~h}$, para avaliar a infiltração nesses materiais. O IRM e o Coltosol mostraram significantemente menores índices de infiltração de corante que os demais grupos, e o Scoth Bond, teve 
maior penetração que os demais. O Vidrion obteve resultado significantemente pior que o IRM e Coltosol, porém significantemente melhor que o Scoth Bond, e o grupo controle positivo. Os autores concluem que nenhum material quando usados como barreira coronária, foi capaz de evitar completamente a microinfiltração do corante.

A proposta do estudo realizado por GALVAN et al. ${ }^{16}$, em 2002, foi avaliar de forma quantitativa, através do método de filtração de fluído, a efetividade de cinco materiais restauradores, usados como barreira adicional intracoronária após o tratamento endodôntico. Cinquenta e dois molares extraídos humanos foram selecionados, as coroas desses foram removidas na junção cemento-esmalte e também secionados $2 \mathrm{~mm}$ abaixo da região de furca, com disco de alta rotação Isomet. O tecido pulpar foi removido, os canais foram alargados com Gates-Glidden até o $\mathrm{n} \underline{0}-3$, instrumentados, irrigados com $\mathrm{NaOCl}$ a 5,25\% por 2 min, e água destilada por 1 min no final, e obturados com cones médios de guta percha, sem cimento. Grupos aleatórios foram formados, segundo o material usado: Amalgabond, C\&B Metabond, One-Step Dentin Adhesive com resina Eliteflo, One-Step Adhesive com resina Palfique e o material restaurador temporário, IRM, aplicados numa espessura de $3 \mathrm{~mm}$, diretamente sobre os orifícios do canal. Um pó de polimetilmetacrilato (PMMA) foi adicionado ao Amalgabond e ao C\&B Metabond. O grupo controle negativo teve o assoalho pulpar selado com adesivo à base de cianocrilato, e o positivo não teve o canal tratado nem selado. Os espécimes foram acoplados ao dispositivo de transporte de fluído, utilizando-se uma pressão de 3.4 psi ou 239 $\mathrm{cm} / \mathrm{H}_{2} \mathrm{O}$, e feitas avaliações após 1 dia, 1 sem, 1 mês e 3 meses. Durante as medições, as raízes ficaram estocadas em estufa a $37^{\circ}$, e em recipiente com solução salina acrescida de $0,2 \%$ de sódio ácido, um agente antimicrobiano. Após análise estatística, obtiveram-se os seguintes resultados: no grupo positivo houve extrema infiltração, enquanto que no negativo nenhuma; houve também grande diferença entre os materiais, mas não em relação ao tempo; imediatamente após a colocação dos materiais e no primeiro dia, não houve diferenças significantes, mas após 7 dias, as diferenças foram notáveis: Todos adesivos e resinas infiltraram menos que o IRM, sendo o Amalgabond, o que menos infiltrou. Pôde-se concluir que os quatro materiais adesivos são efetivos na diminuição da infiltração coronária, sendo o Amalgabond o que apresentou 
melhores resultados e o IRM, O que demonstrou extensiva infiltração em 1 e 3 meses, contra indicado, portanto para uso por longos períodos. Esses materiais resinosos, então, com o objetivo de evitar a microinfiltração coronária, podem ser usadas em dentes endodonticamente tratados, antes da colocação final da restauração.

TEWARI; TEWARI ${ }^{60}$, ainda no ano de 2002, avaliaram a microinfiltração de materiais temporários, utilizados como seladores intermediários da entrada dos canais após tratamento endodôntico. Dois materiais a base de óxido de zinco eugenol foram testados, o Kalzinol e o ZOE, através do método de infiltração de corantes, com o azul de metileno a $2 \%$, e em diferentes intervalos de tempos (1, 2, 4 e 7 dias). Oitenta dentes humanos extraídos, íntegros, foram selecionados, e após o acesso endodôntico e remoção da polpa, nenhum material foi colocado nos canais, apenas de 4 a 5 $\mathrm{mm}$ de material restaurador nas entradas dos canais, com pressão digital. Todos os dentes foram então radiografados, e armazenados a $100 \%$ de umidade relativa, e dez dentes de cada grupo foram imersos em corantes por 1, 2, 4 ou 7 dias. Após secagem, múltiplas secções foram feitas dos espécimes. No grupo controle positivo, os dentes foram totalmente cobertos com cera, e no negativo nenhum material foi colocado, apenas uma bolinha de algodão. A avaliação foi realizada em estereomicroscópio (aumento de 6x), após o seccionamento mesio-distal dos dentes, e escores para avaliar a profundidade de microinfiltração foram definidos. Os dois materiais infiltraram, de forma variada, em todos intervalos de tempos, houve diferença estatisticamente entre o ZOE e Kalzinol nos dois primeiros dias, sendo que o Kalzinol infiltrou menos. No sétimo dia os dois infiltraram totalmente, em todos espécimes. Os autores recomendam, portanto, a restauração definitiva imediata após o tratamento endodôntico.

TSELNIK et al. ${ }^{64}$, em 2004, tiveram como objetivo medir a infiltração bacteriana de três cimentos usados como barreira provisória, o MTA branco, o cinza e o civ, Fuji II LC. Setenta e oito dentes humanos, extraídos, cortados na junção amelo-cementária, tiveram seus canais instrumentados com sistema rotatório (Dentsply), irrigados com $\mathrm{NaOCl}$ a 5,25\% e EDTA a 15\%, obturados com cimento Kerr EWT e guta percha. Cada grupo de 18 dentes pareados, foram então divididos de acordo com o material selador coronário aplicado, 
numa espessura de $3 \mathrm{~mm}$, ficando em estufa a $37^{\circ} \mathrm{C}$ por 24 horas para secagem dos materiais. Três pares foram usados com controle positivo (sem barreira) e controle negativo (sem barreira e cobertos com resina epóxica). Os espécimes foram mantidos em estufa até secagem dos materiais, e submetidos ao teste de infiltração bacteriana TSB, sendo $5 \mathrm{ml}$ de TSB, colocados assepticamente dentro de cada câmara, e incubados por uma semana para observar se não houve contaminação. Em seguida, 100mL de TSB, foi novamente incubados, desta vez acrescido de saliva humana (2mL), e observado por 24 horas. Após análise dos resultados, o teste de Fisher revelou que o grupo controle positivo infiltrou totalmente; o negativo não, e que nenhuma diferença significante foi observada entre a infiltração dos grupos com Fuji e o MTA, e entre o MTA branco e o cinza, em 30, 60 e 90 dias. Pôdese concluir, dentro das limitações desse estudo, que os três materiais promoveram selamentos coronários aceitáveis, no período de 90 dias.

A proposta de OZTURK et al. ${ }^{33}$, em 2004, foi de avaliar in vitro a capacidade de selamento de cinco sistemas adesivos: Prime\&Bond NT, Prompt L-Pop, Clearfil SE Bond, Scothbodn Multi Purpose Plus e EBS-Multi, colocados na câmara pulpar de 75 dentes (molares humanos) extraídos. Esses dentes foram cortados na porção coronária e também $2 \mathrm{~mm}$ abaixo da região de furca, tiveram seus canais alargados com Gates-Glidden nํㅡ e 3, instrumentados e obturados apenas com cone principal de guta percha, sem cimento. Em seguida, foram divididos em 5 grupos de 15 dentes cada, e os materiais manipulados de acordo com as instruções dos fabricantes e aplicados no assoalho da câmara, numa espessura de $2 \mathrm{~mm}$. Após adaptação dos espécimes em plataformas de acrílico, Plexiglass, e submetidos ao teste de filtração de fluído, numa pressão de $239 \mathrm{~cm} / \mathrm{H}_{2} \mathrm{O}$, ou $23.4 \mathrm{KPa}$. Foram então medidas as infiltrações de 2 em 2 min por 8 min, imediatamente após aplicação dos materiais, 1 dia,1 sem e 1 mês após. Os sistemas adesivos, com exceção do Primer\&Bond NT e Prompt L-Pop, mostraram valores de infiltração diferentes entre os diferentes tempos. O Clearfil SE Bond não mostrou valores diferentes entre a primeira hora e 24 h. Após 1 mês, nenhum dos adesivos mostrou valores de infiltração significantemente diferentes. Foram feitas também avaliações quanto à penetração desses materiais, através da microscopia eletrônica de varredura, em sete dentes humanos extraídos. Pôde- 
se observar que o uso da $\mathrm{NaOCl}$ removeu o colágeno, deixando a dentina amolecida, mas nenhuma camada híbrida foi encontrada nas interfaces dentina/adesivos nos diferentes espécimes.

ZMENER et al. ${ }^{80}$, ainda em 2004, investigaram in vitro as propriedades de selamento de três materiais restauradores temporários: Cavit, IRM e um cimento a base de policarboxilato, o Ultratemp Firm. Foram utilizados 45 dentes humanos, molares, seccionados $3 \mathrm{~mm}$ abaixo da junção amelodentinária e cujo acesso coronário à câmara pulpar, foi padronizado em todos os espécimes, formando cavidades de aproximadamente $4 \times 4 \mathrm{~mm}$. Em seguida, a profundidade desse preparo foi mensurada, os dentes divididos aleatoriamente em três grupos, e $5 \mathrm{~mm}$ de cada material temporário foram inseridos. Após estocagem por $48 \mathrm{~h}$, em estufa a $37^{\circ} \mathrm{C}$, fez-se ciclagem térmica, 500 ciclos em água destilada, variando de $5^{\circ} \mathrm{C}$ a $55^{\circ} \mathrm{C}$, por $30 \mathrm{~s}$ cada dente. Esses espécimes foram protegidos, antes da imersão do corante azul de metileno a $2 \%$, feita por 10 dias a $37^{\circ} \mathrm{C}$, com cera desde a região da junção amelo-dentinária, até o ápice. Cinco dentes foram usados como controle positivo, onde não se usou material temporário, e cinco como negativo, em que além de não se aplicar nenhum material, aplicou-se uma camada de cera em toda extensão dos dentes. A penetração do corante foi medida em $\mathrm{mm}$, usando estereomicroscópio. Os resultados revelaram que o grupo controle positivo obteve total infiltração, e o negativo, nenhuma. Todos infiltraram na interface dentina-esmalte, mas nenhuma diferença estatisticamente significante, foi encontrada na infiltração marginal dos materiais testados, sendo que alguns espécimes selados com IRM, absorveram corante em grande parte do material.

SHIPPER et al. ${ }^{49}$, em 2004, avaliaram a infiltração bacteriana do estreptococcus mutans e do enterococcus faecalis, em canais obturados com cones de guta percha e a base de polímero sintético termoplástico (Resilon), usando duas técnicas de obturação (condensação lateral e vertical), num período de 30 dias. Após eliminarem-se as porções radiculares dos dentes, num total de 156, padronizou-se o comprimento radicular em $16 \mathrm{~mm}$, instrumentou-se com o Sistema Profile e o terço apical, com instrumentos manuais, até $1 \mathrm{~mm}$ do ápice. As irrigações intermediárias foram feitas com $\mathrm{NaOCl}$ a 1,25\%, e a final com 5ml de EDTA a 17\%. Oito grupos de 15 dentes, e três grupos controle (12 dentes) foram formados da seguinte forma: Grupo I e 
II, obturados com guta e AH Plus, com condensação lateral e vertical, e grupos III e IV, com guta e Epiphany, obturados da mesma forma. Grupos V e VI, Resilon e Epiphany, variando também a técnica de obturação, e grupo VII e VIII, da mesma forma que V e VI, só que, nestes últimos utilizou-se infiltração do enterococcus faecalis e nos demais foi usado o estreptococcus mutans. Nos dois grupos controle positivos usaram-se Resilon e guta percha, mas sem cimentos, e no negativo apenas selou-se a câmara pulpar com cera antes do teste. Os positivos infiltraram em 48 horas e no negativo nenhuma infiltração ocorreu. Nos grupos obturados com guta percha, 80\% dos espécimes infiltraram, não importando o cimento, nem a técnica. Nos grupos com Resilon, diferenças estatisticamente significantes foram encontradas, quando comparadas aos demais, sendo sempre menores os valores de infiltração, quando comparados aos com guta percha. Nenhuma diferença de infiltração foi encontrada quando se variou o microrganismo, no grupo do Resilon, porém no grupo com estreptococcus faecalis, a infiltração ocorreu mais cedo. Os autores sugerem que testes in vivo sejam realizados.

MALONEY et al. ${ }^{29}$, em 2005, se propuseram a avaliar, o efeito da termociclagem no cimento de ionômero de vidro, utilizado como barreira coronária através do método de transporte de fluído. Foram utilizados 30 dentes unirradiculares, pré-molares, extraídos, sem fraturas e com comprimento padrão de $18 \mathrm{~mm}$. Após instrumentação manual, os canais foram irrigados com $3 \mathrm{ml}$ de EDTA a $17 \%$, e lavagem final com $3 \mathrm{ml}$ de $\mathrm{NaOCl}$ a $5,25 \%$, os canais foram obturados com guta percha e o cimento Root 801, pela técnica da condensação lateral, removeu-se o excesso de guta e o cimento (4,5mm) e fez-se a limpeza dessa região com álcool a 70\%, mantendo os dentes em estufa por 3 sem. Em seguida, dividiram-se aleatoriamente os espécimes, em três grupos de acordo com o material e espessura de barreira: grupo I, $1 \mathrm{~mm}$ e grupo II, $2 \mathrm{~mm}$ de Triage, cimento de ionômero de vidro modificado por resina, manipulado de acordo com instruções do fabricante e inserido com seringa cêntrix, o grupo III não recebeu barreira e serviu como grupo controle positivo. Após termociclagem de 500 ciclos $\left(5^{\circ} \mathrm{C} / 55^{\circ} \mathrm{C}\right)$, e novamente examinados, um dente do grupo controle foi descartado por fratura. Em seguida, os espécimes foram adaptados ao dispositivo de filtração de fluído, selados com verniz, exceto $2 \mathrm{~mm}$ do ápice, numa pressão de 10 psi, 
sendo testado cada dente três vezes. Observou-se que os dentes que sofreram termociclagem da barreira infiltraram significantemente menos que os sem; não houve diferença estatisticamente significante entre as espessuras de 1 e $2 \mathrm{~mm}$, e houve uma tendência de menos movimento de fluído quando uma barreira mais espessa foi utilizada.

SOUZA et al. ${ }^{54}$, em 2005, visaram avaliar a microinfiltração coronária, através do uso de corante, em dentes em que se realizou a remoção da smear layer, por dois diferentes mecanismos: com EDTA a 17\% e com Er: YAG Laser, e que foram posteriormente selados na região da câmara pulpar, com líquidos adesivos Single Bond e Super Bonder. Foram utilizados 94 dentes humanos extraídos (caninos), instrumentados, irrigados com hipoclorito de sódio 1\% e finalizando com 10ml de água destilada, e divididos em 3 grupos, de 30 dentes, de acordo com o material obturador: grupo 1, obturados pela técnica de condensação vertical com $\mathrm{AH}$ Plus e guta percha, e que foram também subdividido em três grupos de 10 , de acordo com os selamento coronários; com Single Bond, Super Bond e nenhum selamento onde foi colocado, apenas bolinha de algodão e cimento temporário Coltosol; grupo 2, os canais receberam irrigação adicional de $10 \mathrm{ml}$ de EDTA a 17\%, finalizando novamente com $10 \mathrm{ml}$ de água destilada, obturados e subdivididos e selados da mesma forma; grupo 3, os espécimes receberam após irrigação com hipoclorito, a aplicação final de Er:YAG Laser, em quatro aplicações com 30 segundos, de intervalo, num total de 48 segundos de aplicação. Nesse período os canais estavam preenchidos com água destilada e deionizada. Novamente a irrigação final foi feita da mesma forma, e os 30 dentes, subdivididos como os anteriores. Após estocagem em estufa, por 1 sem, todos os espécimes foram impermeabilizados com 3 camadas de adesivo a base de cianocrilato, exceto 1 $\mathrm{mm}$ das entradas dos canais. Dois dentes controle positivo e dois controle negativo, onde se irrigou apenas com $\mathrm{NaOCl}$ a $1 \%$, obturou apenas com guta percha, e não se selou, sendo que no negativo os dentes receberam impermeabilização total. O corante usado para imersão foi o Índia Ink por 90 dias. Em seguida, os espécimes foram descalcificados, desidratados, cortados limpos e avaliados em microscópio. O grupo controle positivo teve maior valor de infiltração; os grupos com EDTA e os tratados com Laser, tiveram valores similares entre si, e os selados com líquidos adesivos, tiveram 
significantemente redução da infiltração coronária quando comparados com os demais, sendo que o Super Bond mostrou-se mais efetivo que o Single Bond. Nenhuma das técnicas reduziu 100\% o risco de infiltração após 90 dias.

CHERSONI et al. ${ }^{11}$, em 2005, avaliaram a permeabilidade de diferentes sistemas adesivos, convencionais e simplificados, quando aplicados na dentina radicular de 38 dentes, unirradiculares, tratados endodonticamente, obturados pela técnica da condensação vertical com guta percha e cimento CRCS. Após a obturação, os canais foram preparados para receberem um pino de fibra de vidro, radiopaco, removendo-se parte da obturação; então a dentina nesta região foi limpa e avaliada em microscopia para certificar se estava livre de restos de materiais e através de radiografias observou-se nesta região, pelo menos, cerca de 1,5mm espessura de parede dentinária. Quatro sistemas adesivos foram testados: All-Bond 2, um convencional de três passos; Single Bond e One-Step Plus, ambos simplificados de dois passos; Tyrian SPE/OneStep Plus e One-Up Bond F, simplificados de passo único. Todos foram aplicados e polimerizados. Imediatamente após, uma moldagem foi realizada, com um material de impressão, polivinilsiloxano; após 24 horas, foi obtida então, a partir desta, uma réplica em positivo com outro material, o poliéter. Essas réplicas foram hemi-seccionadas, preparadas e ao exame de microscopia eletrônica, observou-se: diferentes formações em forma de gotas de fluídos, sendo que o All-Bond 2 exibiu significantemente menos formações que os outros 5 grupos, não havendo porém entre esses, diferenças significantes.

GARCÍA-GODOY et al. ${ }^{17}$, em 2005, avaliaram a formação de camada híbrida e potencial de nanoinfiltração, após irrigação dos canais radiculares, durante a instrumentação com soluções de EDTA a 17\%, MTDA Biopure e solução salina pura, por 5 min., e posterior obturação com cimento hidrofílico a base de metacrilato, Endorez, em conjunto com guta percha, injetado 2 a $3 \mathrm{~mm}$ do comprimento de trabalho. Após limpeza da região coronária e confirmação radiográfica, um adesivo Xeno III, foi aplicado no intraorifício do canal, fotopolimerizado e seguido pela aplicação de um civ Fuji Triage Pink Capsule. Os espécimes foram mantidos em $37^{\circ} \mathrm{C}$ e $100 \%$ de umidade relativa por 24 horas. Em seguida, fez-se a avaliação dos espécimes, nos terços coronários, médios e apicais, em microscopia eletrônica de 
transmissão e observou-se que os dois irrigantes, EDTA e MTDA removeram detritos de até $2 \mu \mathrm{m}$ de smear layer, mas que a camada híbrida formada pelo MTDA era mais fina que a formada pelo EDTA, sendo que os dois causam desmineralização das matrizes de colágeno da dentina radicular, que pode causar colapso e permitir uma ótima infiltração do cimento nas paredes do canal.

Baseando-se na importância do selamento dos orifícios na embocadura dos canais radiculares após tratamento endodôntico, visando impedir a penetração de bactérias, caso haja uma perda ou infiltração na restauração temporária, JENKINS et al. ${ }^{24}$, em 2006, realizaram um estudo, investigando a habilidade de selamento de três materiais restauradores temporários, em quatro diferentes espessuras, após obturação dos canais. Foram utilizados 130 dentes unirradiculares, que depois do devido preparo: remoção de detritos orgânicos, corte da porção coronária, instrumentação e obturação pela técnica da condensação lateral com guta percha aquecida e Termaseal Plus, foram divididos de maneira aleatória, em 12 grupos, de 10 dentes cada, e dois grupos controle, de acordo com o material selador utilizado: ProRoot MTA, Tetric ou Cavit, nas espessuras de 1, 2, 3 e 4 mm. Uma camada de esmalte cosmético foi colocada por toda extensão da raiz. Cinco dentes fizeram parte do grupo controle positivo, instrumentados e obturados com guta percha sem que se utilizasse o verniz, e cinco do negativo, onde não se aplicou o verniz em toda sua extensão, incluindo o orifício. As amostras foram imersas em corante Índia Ink, submetidas a uma pressão de 75 rotações por 35 min e ficando imersos por mais sete dias, foram lavadas, em seguida, fez-se a remoção do corante, e desmineralização em ácido nítrico a $5 \%$, por cinco dias. Após isso, foram estocados individualmente em $5 \mathrm{ml}$ de álcool a 80\% por 12 horas, e recolocadas e álcool a 100\% por mais 2 horas. Para completar o processo, as raízes foram estocadas em $6 \mathrm{ml}$ de solução de metilsalicilato. Os espécimes foram então observados e a infiltração mensurada com um estereomicroscópio (10x), indicando que o Tetric tem potencial maior e significantemente melhor, de prevenir a infiltração do que os outros dois materiais, quando usado como barreira adicional, entretanto esse estudo foi feito por apenas 7 dias e não se observaram diferenças significantes de selamento, em relação às espessuras da barreira. 
STRATTON et al. ${ }^{55}$, em 2006, tiveram como objetivo comparar in vitro, a capacidade de selamento do AH Plus e guta percha, em relação ao Epiphany e Resilon, variando apenas o agente irrigador final. Cento e quarenta dentes foram empregados, o comprimento de trabalho foi estabelecido a $1 \mathrm{~mm}$ do ápice, e os canais instrumentados com o Sistema Profile, e o batente definido com a lima no 50 Flex-R. A porção coronária $(6 \mathrm{~mm})$ do canal foi preparada com broca de Gates Glidden nํ-2 e 4. Durante a instrumentação $3 \mathrm{~mL}$ de $\mathrm{NaOCl}$ a 4,25\%, foi usada entre cada instrumento, sendo a irrigação final feita com $3 \mathrm{~mL}$ de EDTA a 17\%, por 3 min, seguido por $3 \mathrm{ml}$ de $\mathrm{NaOCl}$ por mais 3 minutos. Em seguida, dividiram-se os espécimes em três grupos de 40, sendo que 20 dentes serviram como controle, de acordo com a solução irrigadora, sempre 3mL por 10 minutos: grupo I, $\mathrm{NaOCl}$ a 5,25\%; grupo II, glucanato de clorexidina a $0,12 \%$ e grupo III, glucanato de clorexidina a $2 \%$. Após secagem, cada grupo foi subdividido em dois, em que no subgrupo $A$, obturou-se com guta e AH Plus, e no subgrupo B, com Epiphany e Resilon. Dez espécimes do grupo controle foram obturados apenas com Resilon, e dez, apenas com Guta percha. O grupo controle negativo foi um tubo de aço, obturado com resina acrílica. Até a realização dos testes os dentes ficaram estocados em estufa a $100 \%$ de umidade relativa e a $37^{\circ} \mathrm{C}$, por 20 dias, para completa secagem dos cimentos. Para medição da capacidade de selamento, o método de transporte de fluído foi utilizado, numa pressão de 10psi. Nessas condições encontrou-se que os grupos com Epiphany e Resilon, apresentaram significantemente melhor capacidade seladora que os outros, não sendo encontrada nenhuma diferença significante, quando se variou a solução irrigadora.

TUNGA; BODRUMLU ${ }^{65}$, em 2006, avaliaram in vitro a capacidade de selamento do cimento endodôntico resinoso Epiphany, usado em conjunto com o cone resinoso Resilon, com a dos cimentos endodônticos AH Plus e AH 26, ambos usados com guta percha. A avaliação foi feita através do método de filtração de fluído. Sessenta e seis dentes humanos unirradiculares, foram seccionados na junção cemento-esmalte, instrumentados a $1 \mathrm{~mm}$ do ápice com limas tipo $K, n^{\circ}$ 40, pela técnica step-back e o terço coronário das raízes, foi instrumentado com brocas Gates Glidden nํ2 a 6. Em seguida, após irrigação com $10 \mathrm{~mL}$ de $\mathrm{NaOCl}$ a 5,25\%, fez-se irrigação final com 10ml de EDTA a 17\%, 
secagem e obturação pela técnica da condensação lateral, com os referidos cimentos, formando três grupos de 18 espécimes cada, seguindo as instruções dos fabricantes. As amostras foram então mantidas em solução salina a $37^{\circ} \mathrm{C}$, por 48 horas, e a infiltração foi então mensurada por 3 horas, de hora em hora, numa pressão de 1,2 atm. Os resultados indicaram que a menor infiltração foi obtida com o Epiphany e Resilon, com diferenças estatisticamente significantes entre os grupos, sendo que o AH 26, apresentou maiores valores de infiltração.

BIGGS et $\mathrm{al}^{6}$, também em 2006, compararam in vitro a habilidade de selamento do Epiphany e Resilon, com a dos cimentos AH Plus e Roth canal, em associação com guta percha, medindo a infiltração através do método de filtração de fluído. Noventa e seis dentes humanos, unirradiculares, tiveram suas coroas removidas, foram instrumentados a $1 \mathrm{~mm}$ do ápice, com limas tipo $\mathrm{K}$ até o tamanho 90, padronizando a porção coronária da raiz com brocas Gates Glidden n-2, 3 e 4. Os canais foram irrigados com $\mathrm{NaOCl}$ a 2,6\% após cada instrumento. Grupos de 12 espécimes cada foram formados, estocados em água estéril, e após a obturação procederam-se as medições realizadas inicialmente após 24 h, e depois com 1 sem, 2 sem, 30 dias e 90 dias. Nesse período, os dentes ficaram armazenados a $37^{\circ} \mathrm{C}$, em solução de saliva artificial. As obturações, sempre pela técnica da condensação lateral, distribuiram-se da seguinte forma: grupo I, Epiphany + Resilon, polimerizado por 40 seg; grupo II, Roth canal + guta percha, ficando incubados a $37^{\circ} \mathrm{C}$, por 3 semanas até a primeira medição; grupo III, igual ao 2, sendo que se mediu a infiltração logo após a obturação, sem esperar a presa final do cimento; grupo IV, igual ao I, só que obturados pela técnica do cone único; grupo $\mathrm{V}$, como o I, só que sem primer e sem cimento, serviu como controle positivo; grupo $\mathrm{VI}, \mathrm{AH}$ Plus + guta percha, sendo o teste realizado imediatamente após obturação; grupo VII, como o VI, só que depois os dentes ficaram estocados por 8 horas em estufa a $37^{\circ} \mathrm{C}$, até o primeiro teste e grupo VIII, como o I, sendo que a superfície externa da raiz foi coberta com três camadas de verniz e serviu como controle negativo. Obtiveram-se os seguintes resultados em relação à capacidade de selamento: o grupo $\mathrm{V}$, Resilon/Epiphany sem cimento e sem primer infiltrou significantemente mais que os demais grupos; a menor infiltração foi obtida no grupo controle negativo; não houve diferença nos valores de selamento entre o grupo VI, em que se mediu imediatamente e o VII, nem entre os grupos II e III, 
apesar dos valores terem sido altos e finalmente, o Resilon + Epiphany foram equivalentes, mas não superiores aos demais cimentos e guta percha, sendo significantemente iguais no caso do AH Plus + guta percha.

PITOUT et al. ${ }^{38}$, em 2006, tiveram como objetivo comparar in vitro a microinfiltração de canais obturados com o Sistema Resilon/Epiphany, com a de canais obturados com guta percha e cimento Roth, através de duas técnicas obturadoras, a de condensação lateral e a Sistema B. Cento e dez dentes humanos unirradiculares tiveram a porção coronária removida; foram instrumentados com o Sistema Profile, irrigados com $\mathrm{NaOCl}$ a $5 \%$, com EDTA a $17 \%$ e finalmente com água deionizada. Em seguida foram divididos em 4 grupos de 20 dentes e dois controles de 5 dentes cada, um positivo e um negativo. O grupo I, foi obturado pela técnica de condensação lateral com guta percha e cimento Roth e o II também, só que pelo Sistema B; o grupo III pelo sistema Epiphany pela técnica de condensação lateral e o IV pela outra técnica. Os espécimes foram cobertos com esmalte cosmético, deixando $2 \mathrm{~mm}$ do ápice e a porção coronária descobertos, e então adaptados a um dispositivo de teste bacteriológico, contendo enterococcus faecallis, mantidos assim por 3 meses, a $37^{\circ} \mathrm{C}$, e avaliados periodicamente, quando então o crescimento bacteriano foi verificado, encontrando-se os seguintes resultados: nenhuma diferença significante entre os cimentos e entre as diferentes técnicas. Em seguida o teste de infiltração com corante Índia foi realizado, deixando os espécimes imersos por $72 \mathrm{~h}$, antes de seccioná-los no longo eixo. A leitura foi feita num estéreo microscópio (aumento de 8x) e avaliados por escores préestabelecidos. Nenhuma diferença significante foi encontrada entre o grupo com guta percha + cimento e o com Epiphany pela técnica da condensação lateral ou pelo Sistema B. Os dois materiais apresentaram valores de selamento similares.

BARTHEL et al. $^{3}$, em 2006, avaliaram a capacidade de selamento a longo prazo de 130 dentes humanos, unirradiculares, obturados e selados com materiais restauradores temporários e sistemas adesivos, através de um teste de infiltração bacteriana. Os dentes foram seccionados na porção coronária e então se padronizou o comprimento radicular em $14 \mathrm{~mm}$. Cavidades de $3 \mathrm{~mm} X$ 2.5mm foram preparadas na porção coronária das raízes. A instrumentação foi realizada pela técnica step-back, os canais irrigados com $\mathrm{NaOCl}$ a $2,5 \%$ e 
como irrigante final usou-se EDTA a 5\%. Cinco dentes foram obturados pela técnica da condensação lateral com $\mathrm{AH} 26$ e guta percha e não foram selados; três foram obturados da mesma forma e completamente cobertos de cera e serviram com controle negativo, e dois não foram obturados nem selados e serviram como grupo controle positivo. Os outros cento e vinte espécimes foram obturados da mesma forma, e então divididos em seis grupos de vinte, de acordo com o material utilizado no selamento: Grupo I, New Bond (adesivo) + Clearfil (resina); Grupo II, Optibond Solo (adesivo) + CoreRestore (resina); Grupo III, Ketac Fil (civ); Grupo IV, IRM (cimento de óxido de zinco eugenol reforçado). Dois grupos experimentais foram selados com IRM e Ketac Fil, sendo que antes foi aplicada uma fina camada de cera na abertura dos canais obturados. Em seguida, todas as raízes foram cobertas com cera exceto à $1 \mathrm{~mm}$ do ápice, esterelizadas em óxido etileno, e $5 \mathrm{~mm}$ das raízes foram imersas em tubos de polietileno contendo $10 \mathrm{ml}$ de solução estéril. Na superfície da câmara foi aplicado $3 \mathrm{ml}$ de um caldo contendo Staphylococus epidermidis e streptomicina, sendo mantidos em estufa a $37^{\circ} \mathrm{C}$, por 1 ano, sendo nos primeiros três meses verificadas, três vezes por semana, a ocorrência de turbulência que indicaria crescimento bacteriano, e a partir do quarto mês verificada apenas de quarto em quatro semanas. Nenhuma diferença significante de infiltração foi encontrada entre os grupos no final dos 12 meses. No início do experimento o IRM apresentou a pior performance e o Clearfil o material que nos dozes meses apresentou melhores resultados. 


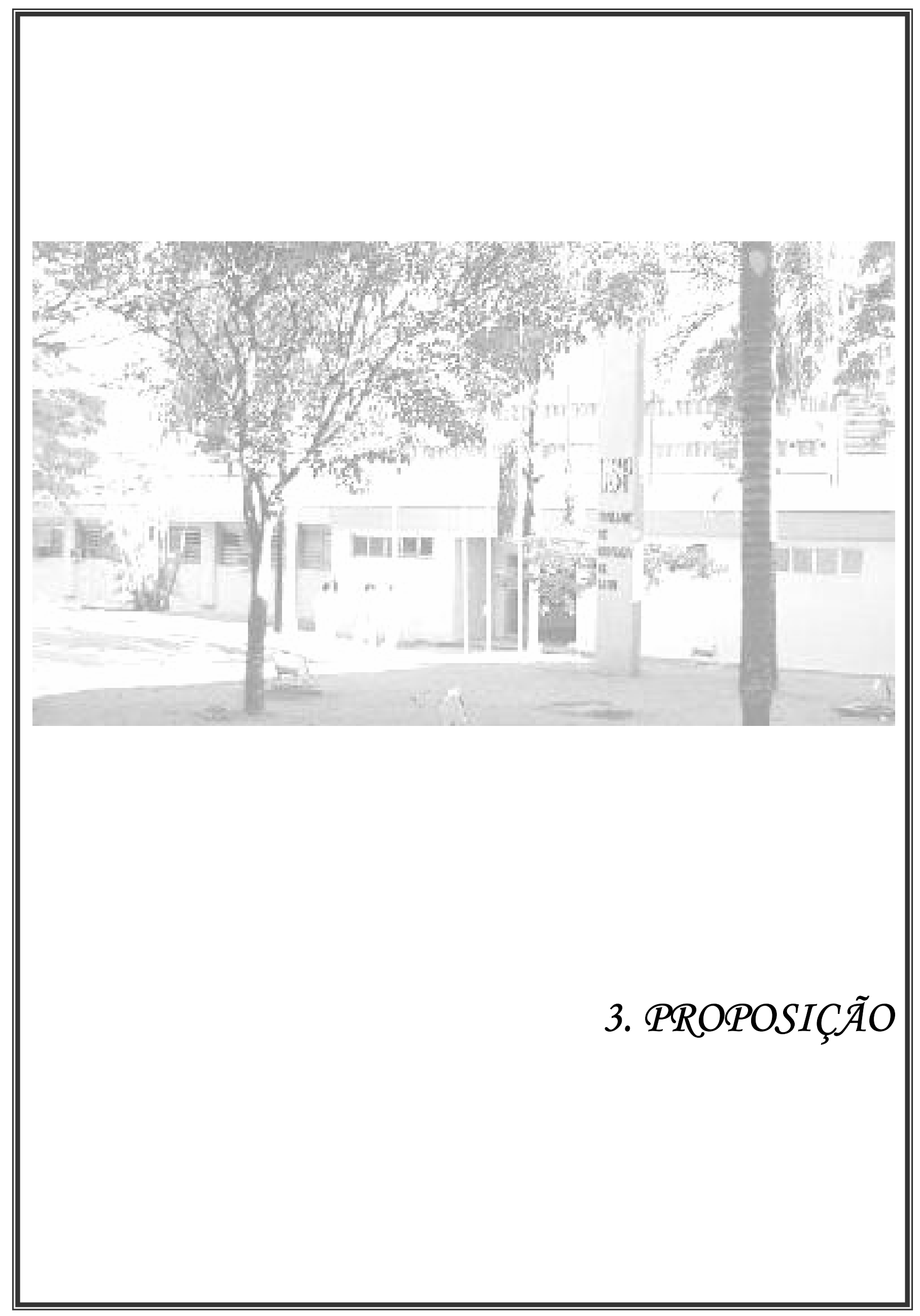




\section{3 - PROPOSIÇÃO}

Em vista da revisão bibliográfica realizada, consultando importantes trabalhos publicados sobre a possibilidade de infiltração pelos canais radiculares tratados endodonticamente, iniciadas nas cavidades coronárias, resolvemos elaborar 0 presente trabalho, com 0 intuito de: avaliar in vitro a infiltração via coronária permitida por canais obturados tendose realizado os seguintes tratamentos: Sistema Epiphany (cone Resilon + cimento resinoso) e obturados com cones de guta-percha + cimento AH Plus e selados intracoronariamente com os seguintes materiais: sistema adesivo Adper Scothbond-Multi-Purpose; Sistema adesivo Adper Single Bond 2 e material restaurador imediato - IRM, utilizando-se para avaliação da eventual infiltração o sistema de transporte de fluído, aplicado em diferentes períodos de tempos (15, 30 e 60 dias), testando a hipótese nula de que não há diferença entre os valores de filtração dos materiais avaliados nos diferentes períodos. 


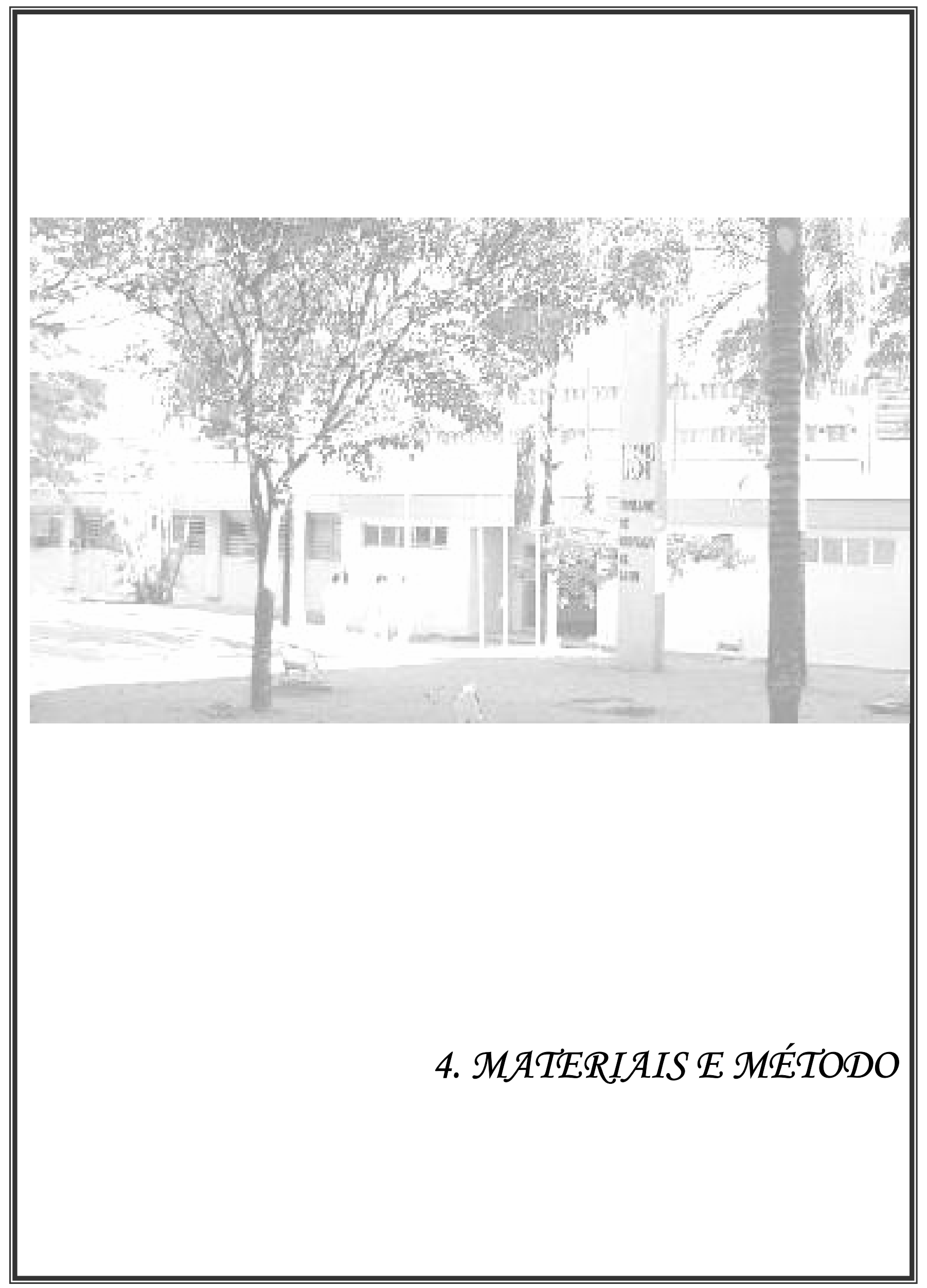




\section{4 - MATERIAIS E MÉTODO}

\section{1 - OBTENÇÃO DOS ESPÉCIMES}

Este trabalho foi aprovado em 22/02/2006, pelo Comitê de Ética em Pesquisa desta Faculdade, e tem o seguinte número de processo: 144/2005 (ANEXO 1). Foram utilizadas 40 raízes, unirradiculares, de dentes humanos, incisivos superiores, coletados no Centro de Urgência da FOB-USP, após o esclarecimento e livre-consentimento dos doadores (ANEXO 2), também de acordo com a resolução do Comitê de Ética em Pesquisa da FOBUSP.

\section{2 - PREPARO DOS ESPÉCIMES (FIGURA 1)}

Os dentes, logo após a extração foram estocados, ficando por um mês, em solução de formol a 2\%, pH 7,0, preparado com tampão fosfato, fornecida pelo Departamento de Bioquímica da FOB-USP. Em seguida, procedeu-se a remoção, de tecidos moles e cálculos, para então, serem armazenados em solução fisiológica com timol a 0,1\%, trocada mensalmente, e mantida sob refrigeração em câmara fria entre $0^{\circ} \mathrm{C}$ e $8^{\circ} \mathrm{C}$, até o início do experimento.

Os dentes foram fixados com godiva termoativada em uma placa de acrílico (40x40×5mm), a qual foi acoplada numa máquina de corte (modelo 650, SBT- South Bay Technology inc., USA), e a porção coronária de cada dente foi então removida na junção amelo-dentinária, com um disco adiamantado, em baixa velocidade, sob refrigeração, tendo a porção radicular sido cortada com o mesmo aparelho na porção apical, mantendo o comprimento padronizado em 10mm. O preparo e obturação dos canais radiculares foram realizados, sempre pelo mesmo operador, iniciando-se pela localização dos canais com lima K n015 (Maillefer, Ballaigües, Suíça), determinação do comprimento real de trabalho, padronização do forame apical em toda sua extensão até lima $\mathrm{K}$ nํㅜ 30. Quando o diâmetro anatômico do forame era maior que o dessa lima, a raiz era descartada. Inicialmente brocas de Gates-Glidden nํㅜ 3 e 4 (Maillefer, Ballaigües, Suíça) foram usadas na porção coronária do canal (4mm) visando 
padronizar essa região, onde seria colocado posteriormente o material selador. A instrumentação dos canais foi realizada por meio da técnica escalonada regressiva ${ }^{25}$, estabelecendo-se o degrau apical da instrumentação a $1 \mathrm{~mm}$ aquém da extensão total e tendo como instrumento de memória a lima $\mathrm{K} \mathrm{n}^{\circ} 50$, e escalonando até a lima $K \mathrm{n}^{\circ}$ 80. Ao final, a lima $K \mathrm{n}^{\circ} 30$ foi introduzida no comprimento real da raiz para remoção de raspas de dentina oriundas do preparo biomecânico, promovendo assim a limpeza do forame. A cada troca de instrumento, os canais foram irrigados com solução de $\mathrm{NaOCl}$ a 2,5\% (Myako do Brasil Ind. e com.Itda., São Paulo, Brasil) cerca de $2 \mathrm{~mL}$, neutralizados com $5 \mathrm{~mL}$ de soro fisiológico. Terminada a instrumentação os canais preparados foram inundados com EDTA a 17\% por 3 min (Biodinâmica Química e Farmacêutica Ltda., Ibiporã, Brasil), para remoção da smear layer, finalizando novamente com irrigação com $5 \mathrm{~mL}$ de soro fisiológico, sendo posteriormente secos com pontas de papel absorvente $\mathrm{n}^{0} 50$ (Dentsply Latin America). Os espécimes foram então divididos inicialmente em dois grupos de acordo com cada material obturador empregado (Tabela 1):

Grupo I (30 raízes) - cone de guta percha + cimento AH Plus (cimento a base de resina epóxica) - (Dentsply - De Trey- Konstanz Germany).

Grupo II (10 raízes)- Sistema Epiphany (cone Resilon + adesivo + cimento resinoso) - Soft Resin Endodontic Obturation System ( Pentron Clinical Technologies, Wallingford, CT, USA).

Os dentes do grupo I foram obturados pela técnica do cone único, na qual se levou o cimento, antes ao canal com ajuda de uma espiral Lentullo $\mathrm{n}-4$ (Maillefer, Ballaigües, Suíça), acionada por seis vezes, e então se introduziu o cone principal nº50 (Maillefer, Ballaigües, Suíça). Após a verificação do extravasamento do cimento o excesso no ápice foi removido por meio de gaze. O excesso dos cones foi cortado $4 \mathrm{~mm}$ abaixo da abertura cervical, com auxílio de um calcador endodôntico aquecido, e a limpeza final da câmara coronária, efetuada com bolinhas de algodão e álcool absoluto.

Os dentes do grupo II foram obturados segundo instrução dos fabricantes para esse sistema: aplicação do Epifhany self-etching primer nas paredes do canal, com pincel, remoção dos excessos com pontas de papel absorvente, colocação do Epifhany sealer, com uma espiral Lentullo $\mathrm{n}-4$, e 
finalmente, um cone principal de resina (Resilon), foi inserido no comprimento de trabalho. Todo o sistema teve a ativação realizada imediatamente com luz de lâmpada halógena por 40 segundos (Degulux soft star- Degussa - Hüls AG).

Os espécimes do grupo I foram subdivididos de forma aleatória, em três grupos de 10, de acordo com os materiais utilizados no selamento intracoronário imediato, da seguinte forma:

Grupo I A (10 espécimes)- Selamento provisório com cimento de óxido de zinco e eugenol reforçado - IRM (Dentsply - Brasil)

Grupo I B (10 espécimes)- Selamento com Adper Scothbond Multi Purpose Plus (3M ESPE- USA)

Grupo I C (10 espécimes)- Selamento com Adper Single Bond 2 (3M ESPE- USA)

Os dez espécimes do Grupo II não receberam nenhum material selador coronário, sendo feita apenas a fotopolimerização do sistema obturador (cimento + cone resinoso) no final da obturação, segundo indicação do fabricante.

Os materiais para o selamento intracoronário, foram manipulados de acordo com a indicação do fabricante, e aplicados no assoalho da câmara pulpar, numa espessura de $4 \mathrm{~mm}$, da seguinte forma:

Grupo I A- IRM: uma porção de pó para uma gota de líquido, espatulação e inserção com instrumento manual e condensação com bolinha de algodão;

Grupo I B- Adper Scothbond Multi Purpose Plus (3M ESPE - USA) ataque da superfície com ácido fosfórico a 37\% (Condicionador Dental Gel Dentisply Latin América) por 15 seg, lavagem com água deionizada por 15 seg, secagem com papel absorvente, aplicação do primer, secagem levemente com jato de ar por 5 seg, aplicação de duas gotas do adesivo, fotoativação por 10 seg, seguida quando necessário pela aplicação de mais duas gotas e nova fotoativação; pois segundo estudo feito por ZAIA, et al. ${ }^{79}$, em 2002 , duas gotas deste adesivo equivalem após polimerizadas a uma camada de aproximadamente $2 \mathrm{~mm}$ de espessura deste material;

Grupo I C- Adper Single Bond 2 (3M ESPE- USA) - ataque da superfície com ácido fosfórico à 37\% por 15 seg, lavagem por 15 seg., 
aplicação do adesivo em duas camadas consecutivas, espera por 15 seg. para evaporação do solvente, fotoativação por 10 seg.

Grupo II- como referido acima, as raízes deste grupo não receberam material selador coronário, sendo cortado o cone resinoso na entrada do orifício do canal radicular antes da fotoativação. 
FIGURA 1 - Fluxograma - Preparo dos Espécimes

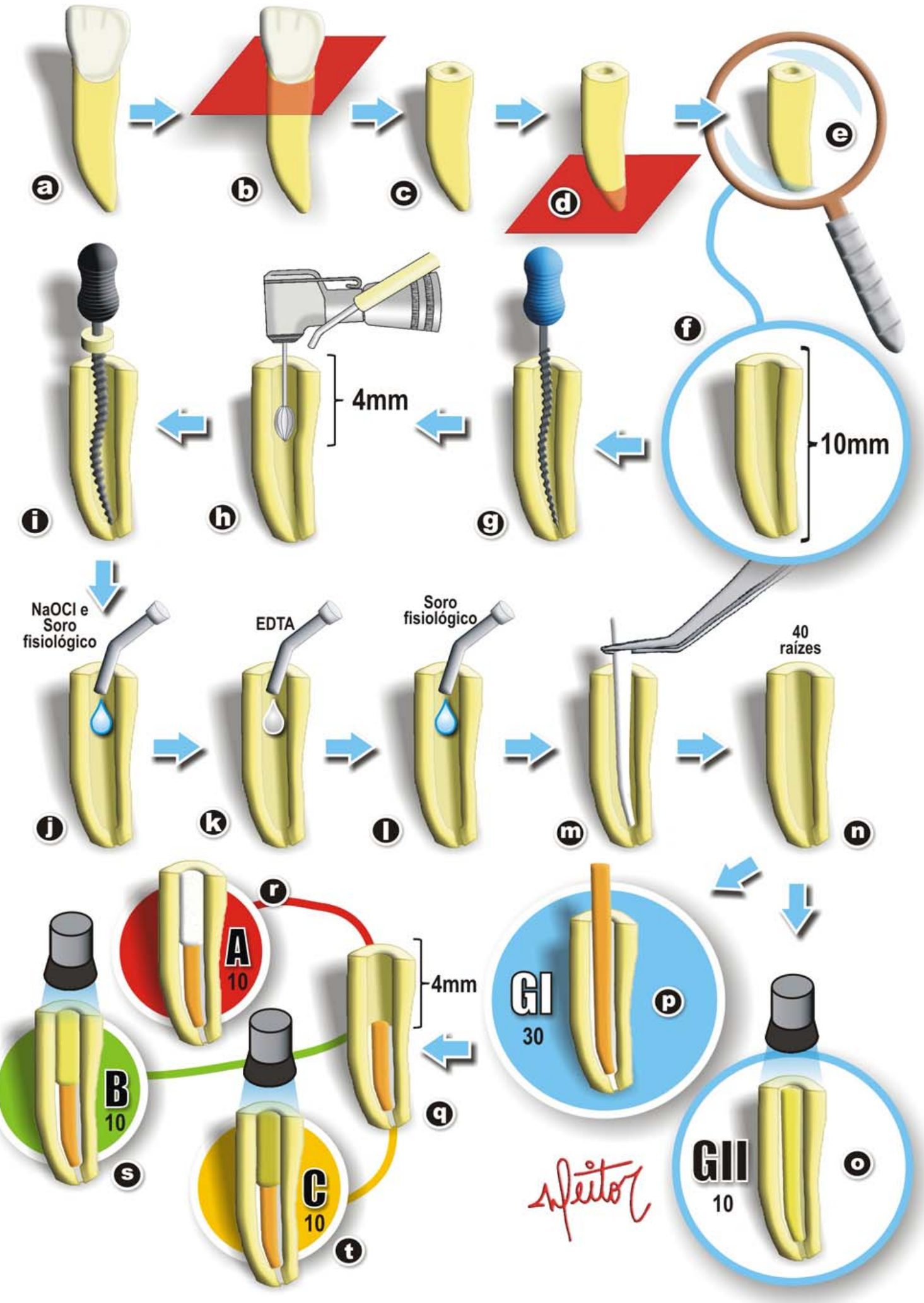




\section{3 - SISTEMA DE FILTRAÇÃO DE FLUÍDO}

O sistema de filtração de fluído (FIGURA 2) foi usado para avaliar longitudinalmente a qualidade de selamento dos espécimes, através das medições de filtração, inicialmente após 15 dias, e após 30 e 60 dias. Durante estes períodos, os espécimes ficaram armazenados em estufa com 100\% de umidade relativa e a $37^{\circ} \mathrm{C}$.

Os dispositivos utilizados para adaptação dos espécimes, representam a parte final do sistema de medição e ficam conectados ao mesmo por meio de capilares de polietileno. Os espécimes foram adaptados tendo a porção coronária dos segmentos radiculares centralizadas em uma plataforma de acrílico transparente de $2 \times 2 \times 0,7 \mathrm{~cm}$ com um adesivo à base de cianoacrilato (Adesivo Instantâneo Super Bonder - Loctite Henkel Ltda., Itapevi, Brasil). Nessa plataforma, foi feito inicialmente um orifício central, coincidindo com a abertura na câmara pulpar do espécime, de diâmetro compatível com o de uma agulha de aço inoxidável (Agulha descartável 20×40, gauge 18, BD Indústrias Cirúrgicas Ltda., Curitiba, Brasil), aproximadamente $0.1014 \mathrm{~cm}$ de diâmetro, que após a remoção do seu bisel, foi justaposta ao orifício, e também fixada com a mesma cola, tendo-se cuidado para que não penetrasse na região cervical ou na luz dos capilares e não se obstruisse a leitura nos espécimes. Um tubo de gauge 18 (Sistema Capilar de Polietileno CPL Medicals Produtos Médicos Ltda., São Paulo, Brasil) foi conectado a essa agulha e a uma micropipeta que tinha um comprimento de $65 \mathrm{~mm}$, com um volume total interno de $25 \mu \mathrm{L}$ (MICROCAPS - Drummond Scientific Co. EUA). A avaliação da microinfiltração era obtida pela medida do deslocamento da bolha de ar colocada dentro da pipeta e que podia se movimentar em frente a uma pequena régua milimetrada, conforme o fluido fosse passando pelo conjunto, em direção ao espécime, em função de um tempo (de 2 em 2 min até um total de $8 \mathrm{~min})$. A penetração de fluído nos espécimes, ou seja, a microinfiltração nos materiais seladores provisórios, é expressa em microlitros por minuto, após se realizar as médias nos referidos tempos, e as conversões necessárias. Cada $\mathrm{mm}$ de deslocamento da bolha na micropipeta, equivale a $0.38 \mu \mathrm{L}$ de água. Durante a medição, os espécimes ficaram imersos em água deionizada, num béquer de $200 \mathrm{~mL}$, evitando assim a desidratação da dentina. Todo o sistema também ficou preenchido por água deionizada, numa pressão 
constante de 7.4psi.

FIGURA 2 - Sistema de filtração de fluídos

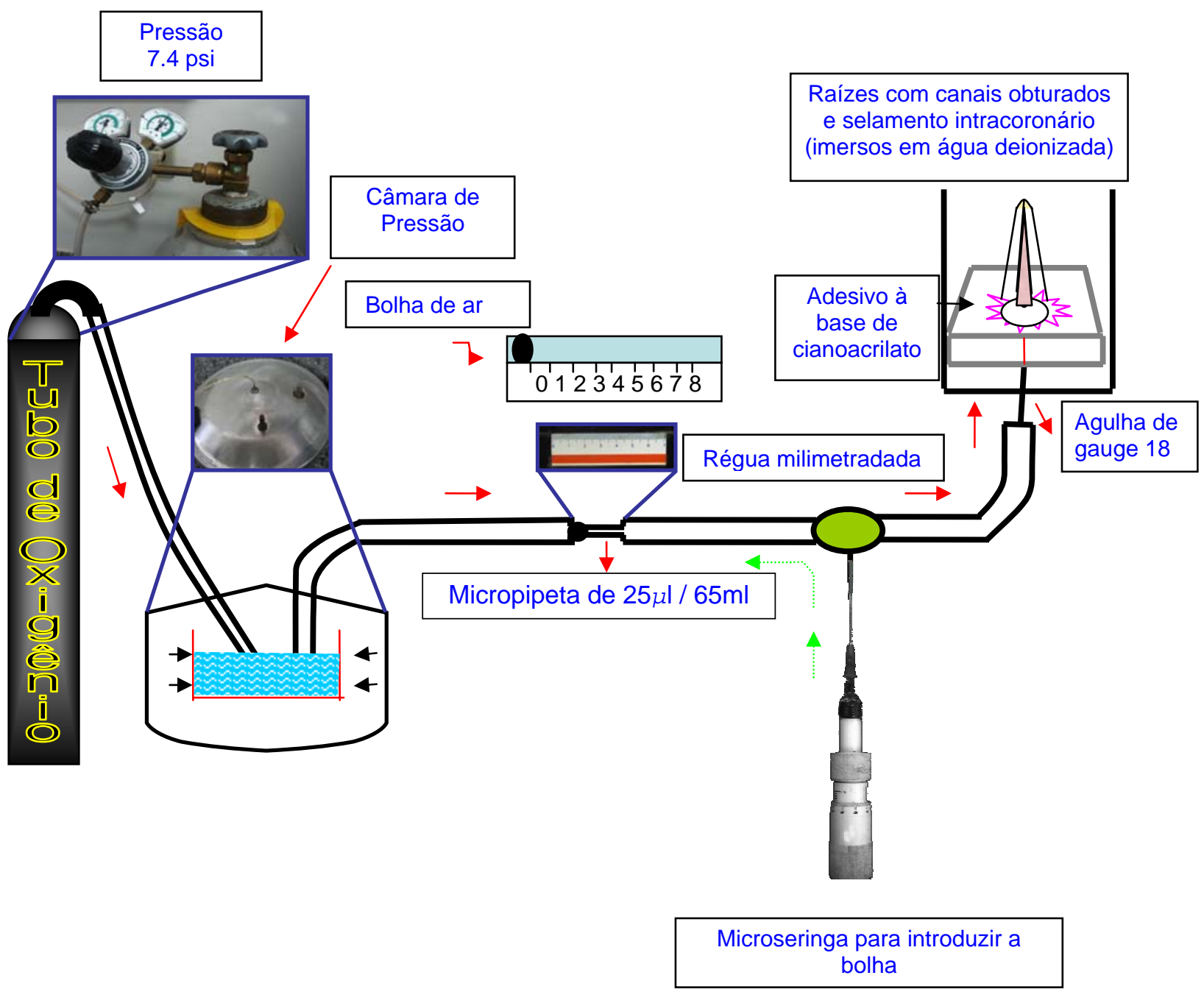




\section{4 - COMPONENTES DO SISTEMA DE FILTRAÇÃO DE FLUÍDO}

\subsubsection{Cilindro de Oxigênio}

O cilindro de metal contendo oxigênio (Cilindro de Oxigênio, White Martins, São Paulo, Brasil) possui uma válvula para liberação do oxigênio e dois manômetros. Um serve para indicar a pressão interna do tubo, ou seja, a quantidade de oxigênio existente e o outro, para estabelecer a pressão que será utilizada no circuito, e que será responsável pela movimentação da bolha no sistema.

\subsubsection{Sistema Capilar de polietileno}

Todo o circuito é composto por um sistema de capilares interligados, que fazem conexão entre a câmara de pressão, a micropipeta, os espécimes e a seringa.

\subsubsection{Câmara de Pressão}

Recebe o oxigênio pressurizado do cilindro de metal e possui no interior um béquer contendo água deionizada, onde fica imersa uma extremidade do capilar de polietileno, que conduzirá essa água, sob pressão, do béquer para o restante do circuito. Quando necessário o volume da água era reposto. Na região superior da câmara, existe uma válvula que permite a descompressão do sistema, quando necessário. A câmara de pressão utilizada neste estudo foi uma panela de pressão adaptada pelo Setor de Mecânica da Faculdade de Odontologia de Bauru, da Universidade de São Paulo, Bauru, São Paulo, Brasil.

\subsubsection{Micropipeta de vidro e régua milimetrada}

Uma micropipeta de $65 \mathrm{~mm}$ de comprimento e de $25 \mu \mathrm{L}$ de volume interno, justaposta a uma régua milimetrada, serve para medir num período de tempo determinado o deslocamento do líquido, através da movimentação de uma bolha de ar que se movimenta dentro da pipeta, introduzida no sistema por uma micro-seringa.

O movimento linear da bolha de ar representa o deslocamento 
volumétrico do líquido no interior dos espécimes, sendo expresso em $\mu \mathrm{L} / \mathrm{min}$. A distância percorrida pela bolha e o tempo gasto para tal, fornecem os cálculos da filtração. Para cada espécime, em cada período de tempo (15, 30 e 60 dias), foram feitas quatro medições num intervalo de 2 em 2 minutos, sendo então calculadas as médias.

4.4.5. Micro-seringa (Syringe Látex free luer-lux- Becton, Dickinson \& Co Franklin Lates, NJ, USA)

Localizada entre o capilar de vidro e o espécime, possui um reservatório de água deionizada $(60 \mathrm{~mL})$ e um êmbolo. É com esse conjunto que se faz a movimentação da bolha de ar no sistema, posicionando-a na região da micropipeta para realizarem-se as medições. 


\subsection{ANÁLISE ESTATÍSTICA DOS RESULTADOS}

Com o objetivo de comparar se existiram diferenças estatisticamente significantes, entre os valores médios de filtração para os diferentes materiais testados entre si e nos diferentes períodos de tempo, realizou-se a análise estatística dos resultados, com a aplicação de testes não paramétricos: Kruskal-Wallis e Friedman. Para comparações múltiplas entre os grupos, quando se encontravam diferenças estatisticamente significantes, utilizou-se o teste de Dunn. 
TABELA 1 - Materiais Testados -

\begin{tabular}{|c|c|}
\hline MATERIAIS & COMPOSIÇÃO \\
\hline $\begin{array}{c}\text { Cimento AH Plus- } \\
\text { Dentsply -DeTrey Konstanz- } \\
\text { Germany }\end{array}$ & $\begin{array}{l}\text { Pasta epóxi - resinas epóxicas; tungstato de cálcio; } \\
\text { óxido de zircônio; sílica e pigmentos de óxido de ferro. } \\
\text { Pasta amina - aminas; tungstato de cálcio; óxido de } \\
\text { zircônio; sílica e óleo de silicone. }\end{array}$ \\
\hline $\begin{array}{l}\text { Epiphany- Soft Resin } \\
\text { Endodontic Obturation } \\
\text { System- Wallingford, USA }\end{array}$ & $\begin{array}{l}\text { Pasta - resinas UDMA (uretano dimetacrilato); } \\
\text { PEGMADMA; EBPADMA; BIS-GMA (bisfenol } \\
\text { glicidilmetacrilato) ; sulfato de bário; sílica; hidróxido de } \\
\text { cálcio; bismuto; aminas; peróxidos; fotoiniciador e } \\
\text { pigmentos. } \\
\text { Cone resinoso-Resilon -polímero sintético termoplástico } \\
\text { (poliéster)- bismuto; sulfato de bário e vidro bioativo. } \\
\text { Resilon Primer -canforoquinona; água; AMPS; HEMA } \\
\text { (hidroximetilmetacrilato); monômeros resinosos. }\end{array}$ \\
\hline $\begin{array}{c}\text { Adesivo Adper Scothbond- } \\
\text { Multi-Purpose -3M } \\
\text { ESPE - USA }\end{array}$ & BIS-GMA; HEMA (hidroximetilmetacrilato); aminas \\
\hline $\begin{array}{c}\text { Primer Adper Scothbond- } \\
\text { Multi-Purpose- 3M ESPE- USA }\end{array}$ & $\begin{array}{l}\text { HEMA (hidroximetilmetacrilato); copolímero de ácido } \\
\text { polialcenóico. }\end{array}$ \\
\hline $\begin{array}{l}\text { Adper Single } \\
\text { Bond } 2 \\
3 M-\text { USA }\end{array}$ & $\begin{array}{l}\text { BIS-GMA; HEMA (hidroximetilmetacrilato); copolímero } \\
\text { de ácido acrílico; diuretano dimetacrilato; glycerol 1; } 3 \\
\text { dimetacrilato; etanol; silano tratado com filler de sílica } \\
\text { ácido itocônico }\end{array}$ \\
\hline $\begin{array}{l}\text { IRM-Material Restaurador } \\
\text { Imediato-Dentsply Brasil }\end{array}$ & $\begin{array}{l}\text { Pó-óxido de zinco e polimetacrilato de metila } \\
\text { Líquido - eugenol }(99,5 \%) \text { e ácido acético }(0,5 \%)\end{array}$ \\
\hline $\begin{array}{c}\text { Guta-percha Pontas-Dentsply } \\
\text { Latin America }\end{array}$ & Óxido de zinco; pigmentos orgânicos e guta percha. \\
\hline
\end{tabular}


Tabela 2 - Identificação do lote e prazo de validade dos principais materiais

\begin{tabular}{|c|c|c|}
\hline MATERIAIS & LOTE & VENCIMENTO \\
\hline $\begin{array}{c}\text { Cimento AH Plus- } \\
\text { Dentsply DeTrey AG, Gm } \\
\text { Konstanz }\end{array}$ & 0603002042 & $2008 / 02$ \\
\hline $\begin{array}{l}\text { Epiphany-Soft Resin } \\
\text { Endodontic Obturation } \\
\text { System- Wallingford, USA }\end{array}$ & $\begin{array}{c}\text { Pasta-00187 } \\
\text { Cone-724 } \\
\text { Primer-00188 }\end{array}$ & $2008 / 05$ \\
\hline $\begin{array}{c}\text { Adesivo Adper Scothbond- } \\
\text { Multi-Purpose- 3M-ESPE- } \\
\text { USA }\end{array}$ & 4NT & $2007 / 06$ \\
\hline $\begin{array}{c}\text { Primer Adper Scothbond- } \\
\text { Multi-Purpose- 3M ESPE- } \\
\text { USA }\end{array}$ & 4AN & $2007 / 05$ \\
\hline $\begin{array}{c}\text { Adper Single Bond 2- 3M- } \\
\text { ESPE- USA }\end{array}$ & $6 \mathrm{GA}$ & $2009 / 01$ \\
\hline $\begin{array}{c}\text { Condicionador Dental Gel - } \\
\text { Dentisply Latin America }\end{array}$ & 391978 & $2008 / 07$ \\
\hline $\begin{array}{l}\text { IRM-Material Restaurador } \\
\text { Imediato - Dentisply Brasil }\end{array}$ & 567777 & $2009 / 05$ \\
\hline $\begin{array}{l}\text { Guta-percha Pontas- } \\
\text { Dentisply Latin America }\end{array}$ & 565358 & $2010 / 03$ \\
\hline
\end{tabular}




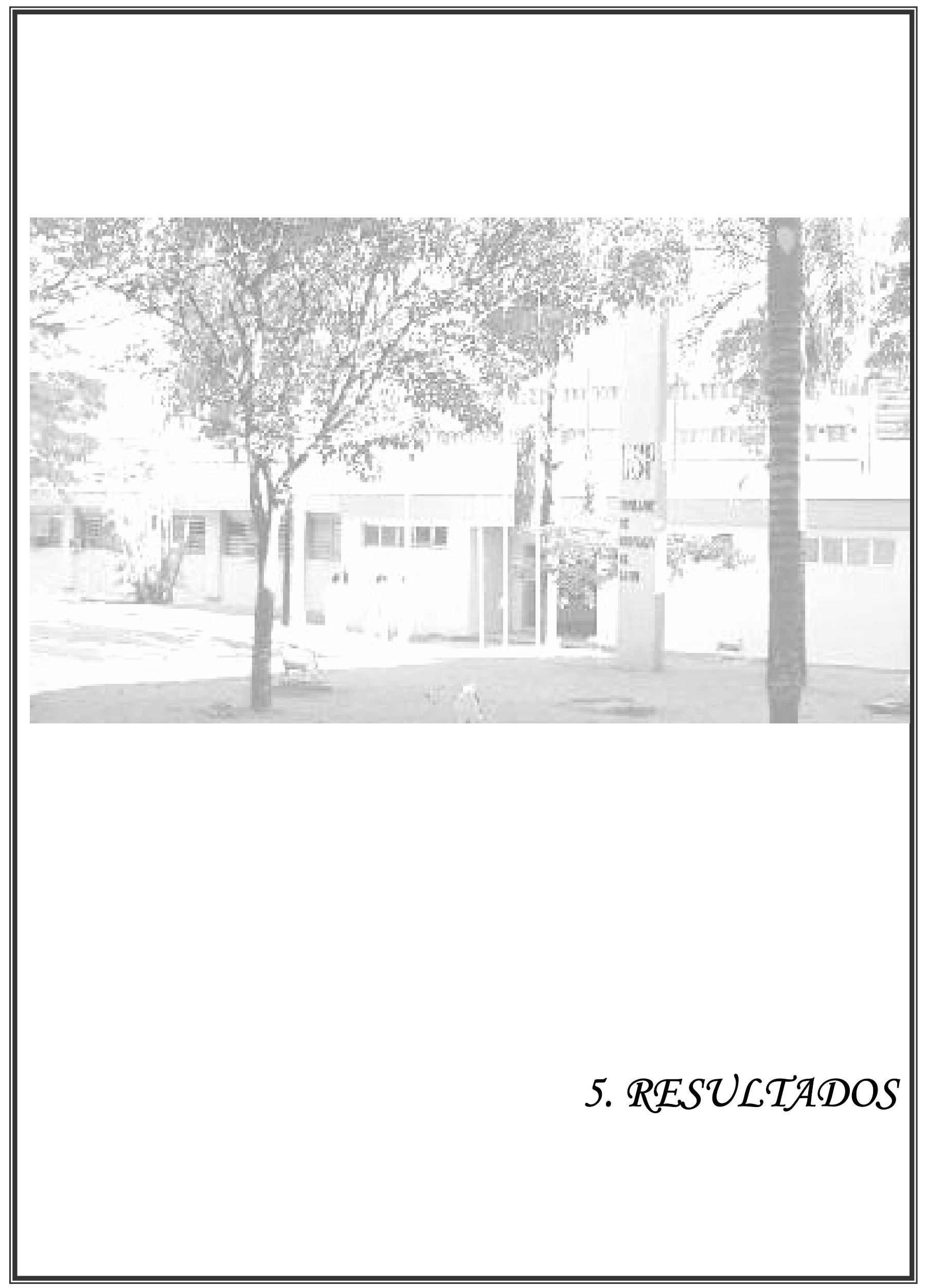




\section{5 - RESULTADOS}

Os dados observados em função do deslocamento da bolha de ar em cada avaliação foram somados com base nos tempos e materiais estudados. Os resultados verificados permitiram obter valores médios de cada período estudado.

A TABELA 3 acolhe os valores médios da distância (em $\mathrm{mm}$ ) percorrida pela bolha de ar no período de 8 minutos do Grupo IA, e suas respectivas médias, onde foram empregados o cimento $\mathrm{AH}$ Plus + guta percha e selamento com IRM, nos diferentes períodos propostos na metodologia.

Tabela 3 - Valores médios da distância (em $\mathrm{mm}$ ), percorrida pela bolha de ar nos períodos de 15, 30 e 60 dias e suas respectivas médias no Grupo IA (Cimento AH Plus + Guta-percha e selamento com IRM)

\begin{tabular}{cccc}
\hline Espécime & $\mathbf{1 5}$ dias & $\mathbf{3 0}^{\text {dias }}$ & $\mathbf{6 0}^{\text {dias }}$ \\
\hline $\mathbf{1}$ & 14,00 & 10,75 & 11,00 \\
$\mathbf{2}$ & 1,00 & 0,75 & 0,75 \\
$\mathbf{3}$ & 0,75 & 8,75 & 63,75 \\
$\mathbf{4}$ & 1,25 & 2,75 & 3,75 \\
$\mathbf{5}$ & 5,50 & 12,50 & 4,25 \\
$\mathbf{6}$ & 1,00 & 1,50 & 1,50 \\
$\mathbf{7}$ & 0,50 & 0,50 & 1,75 \\
$\mathbf{8}$ & 0,75 & 29,50 & 95,75 \\
$\mathbf{9}$ & 0,25 & 2,00 & 1,63 \\
$\mathbf{1 0}$ & 1,25 & 2,75 & 0,25 \\
\hline Média & $\mathbf{2 , 6 3}^{\mathbf{a}}$ & $\mathbf{7 , 1 8}^{\mathbf{a}}$ & $\mathbf{1 8 , 4 4}^{\mathbf{a}}$ \\
\hline
\end{tabular}

*Letras diferentes demonstram diferenças estatisticamente significantes entre os diferentes tempos para o Grupo IA.

Segundo o Teste de Friedman, os valores das médias de filtração do Grupo IA, não apresentaram diferenças estatisticamente significantes $(\rho=0,367)$, nos diferentes tempos testados, considerando $\rho \geq 0,05$. 
A TABELA 4 acolhe os valores médios da distância (em $\mathrm{mm}$ ) percorrida pela bolha de ar no período de 8 minutos do Grupo IB, e suas respectivas médias, onde foram empregados o cimento $\mathrm{AH}$ Plus + guta percha e selamento com sistema adesivo Adper Scothbond Multi Purpose Plus, nos diferentes períodos propostos na metodologia.

Tabela 4 - Valores médios da distância $(\mathrm{em} \mathrm{mm}$ ) percorrida pela bolha de ar nos períodos de 15, 30 e 60 dias e suas respectivas médias, no Grupo IB (Cimento AH Plus + Guta-percha e selamento com sistema adesivo Adper Scothbond Multi Purpose Plus)

\begin{tabular}{cccc}
\hline Espécime & $\mathbf{1 5}$ dias & $\mathbf{3 0}$ dias & $\mathbf{6 0}$ dias \\
\hline $\mathbf{1}$ & 0,75 & 21,00 & 25,00 \\
$\mathbf{2}$ & 0,75 & 0,00 & 0,00 \\
$\mathbf{3}$ & 0,50 & 0,75 & 1,50 \\
$\mathbf{4}$ & 0,75 & 0,50 & 1,25 \\
$\mathbf{5}$ & 0,50 & 5,00 & 3,75 \\
$\mathbf{6}$ & 0,50 & 1,25 & 1,25 \\
$\mathbf{7}$ & 6,50 & 7,50 & 3,75 \\
$\mathbf{8}$ & 1,75 & 0,75 & 0,50 \\
$\mathbf{9}$ & 1,50 & 0,50 & 1,25 \\
$\mathbf{1 0}$ & 1,50 & 0,25 & 0,00 \\
\hline Média & $\mathbf{1 , 5 0}^{\mathbf{a}}$ & $\mathbf{3 , 7 5}$ & $\mathbf{3 , 8 3}$ \\
\hline
\end{tabular}

*Letras diferentes demonstram diferenças estatisticamente significantes entre os diferentes tempos para o Grupo IB.

Segundo Teste de Friedman, os valores das médias de filtração do Grupo IB não apresentaram diferenças estatisticamente significantes ( $\rho$ $=1,000$ ), nos diferentes tempos testados, considerando $\rho \geq 0,05$. 
A TABELA 5 acolhe os valores médios da distância (em $\mathrm{mm}$ ) percorrida pela bolha de ar no período de 8 minutos do Grupo IC, e suas respectivas médias, onde foram empregados o cimento $\mathrm{AH}$ Plus + guta percha e selamento com sistema adesivo Adper Single Bond 2, nos diferentes períodos propostos na metodologia.

Tabela 5 - Valores médios da distância $(\mathrm{em} \mathrm{mm}$ ) percorrida pela bolha de ar nos períodos de 15, 30 e 60 dias, e suas respectivas médias, no Grupo IC (Cimento AH Plus + Guta-percha e selamento com sistema adesivo Adper Single Bond 2)

\begin{tabular}{cccc}
\hline Espécime & $\mathbf{1 5}$ dias & $\mathbf{3 0}$ dias & $\mathbf{6 0}$ dias \\
\hline $\mathbf{1}$ & 0,25 & 21,75 & 20,25 \\
$\mathbf{2}$ & 0,00 & 0,25 & 3,00 \\
$\mathbf{3}$ & 0,75 & 1,00 & 0,50 \\
$\mathbf{4}$ & 0,00 & 0,00 & 0,25 \\
$\mathbf{5}$ & 0,00 & 0,00 & 1,75 \\
$\mathbf{6}$ & 0,00 & 0,00 & 8,00 \\
$\mathbf{7}$ & 0,00 & 0,50 & 0,25 \\
$\mathbf{8}$ & 0,00 & 0,30 & 0,37 \\
$\mathbf{9}$ & 0,00 & 0,00 & 0,75 \\
$\mathbf{1 0}$ & 0,00 & 1,00 & 0,25 \\
\hline Média & $\mathbf{0 , 1 0}^{\mathbf{a}}$ & $\mathbf{2 , 4 8}^{\mathbf{b}}$ & $\mathbf{3 , 5 4 ^ { \mathbf { c } }}$ \\
\hline
\end{tabular}

*Letras diferentes demonstram diferenças estatisticamente significantes entre os diferentes tempos para o Grupo IC.

Segundo o Teste de Friedman, os valores das médias de filtração do Grupo IC apresentaram diferenças estatisticamente significantes $(\rho=0,013)$, nos tempos de 15 e 60 dias, 15 e 60 dias e de 30 e 60 dias, considerando $\rho \geq$ 0,05 . 
A TABELA 6 acolhe os valores médios da distância (em $\mathrm{mm}$ ) percorrida pela bolha de ar no período de 8 minutos do Grupo II, e suas respectivas médias, onde os canais foram obturados com Sistema Epiphany, sem nenhum material selador coronário, nos diferentes períodos propostos na metodologia.

Tabela 6 - Valores médios da distância $(\mathrm{em} \mathrm{mm}$ ) percorrida pela bolha de ar nos períodos de 15, 30 e 60 dias, e suas respectivas médias, no Grupo II (Sistema Epiphany)

\begin{tabular}{cccc}
\hline Espécime & $\mathbf{1 5}$ dias & $\mathbf{3 0}$ dias & $\mathbf{6 0}^{\text {dias }}$ \\
\hline $\mathbf{1}$ & 2,50 & 0,00 & 4,50 \\
$\mathbf{2}$ & 1,00 & 2,25 & 11,75 \\
$\mathbf{3}$ & 0,66 & 1,00 & 3,00 \\
$\mathbf{4}$ & 0,00 & 0,30 & 1,75 \\
$\mathbf{5}$ & 2,00 & 6,25 & 19,75 \\
$\mathbf{6}$ & 1,75 & 0,75 & 4,50 \\
$\mathbf{7}$ & 0,25 & 23,75 & 55,00 \\
$\mathbf{8}$ & 0,50 & 0,75 & 6,25 \\
$\mathbf{9}$ & 0,50 & 0,50 & 1,25 \\
10 & 0,00 & 1,00 & 2,50 \\
\hline Média & $\mathbf{0 , 9 2}^{\mathbf{a}}$ & $\mathbf{3 , 6 6}^{\mathbf{a}}$ & $\mathbf{1 1 , 0 3}^{\mathbf{b}}$ \\
\hline
\end{tabular}

*Letras diferentes demonstram diferenças estatisticamente significantes entre os diferentes tempos para o Grupo II.

Segundo o Teste de Friedman, os valores das médias de filtração do Grupo II apresentaram diferenças estatisticamente significantes $(\rho=0,0002)$, nos tempos de 15 e 60 dias, e de 30 e 60 dias, considerando $\rho \geq 0,05$ 
Os valores médios de filtrações dos Grupos IA, IB, IC e II, foram submetidos ao Teste de Kruskal-Wallis, para comparação entre os grupos nos diferentes tempos 15, 30 e 60 dias e quando foram encontradas diferenças estatisticamente siginficantes entre eles, fez-se o Teste de Dunn para comparações múltiplas. (tabela 7).

Tabela 7 - Valores médios da distância (em $\mathrm{mm}$ ) percorrida pela bolha de ar nos períodos de 15, 30 e 60 dias nos Grupos IA, IB, IC e II.

\begin{tabular}{ccccc}
\hline Dias & IA & IB & IC & II \\
\hline $\mathbf{1 5}$ & $2,63^{\mathrm{a}}$ & $1,5^{\mathrm{a}}$ & $0,10^{\mathrm{b}}$ & $0,92^{\mathrm{ab}}$ \\
$\mathbf{3 0}$ & $7,18^{\mathrm{a}}$ & $3,75^{\mathrm{ab}}$ & $2,48^{\mathrm{b}}$ & $3,66^{\mathrm{ab}}$ \\
$\mathbf{6 0}$ & $18,44^{\mathrm{a}}$ & $3,83^{\mathrm{a}}$ & $3,54^{\mathrm{ab}}$ & $11,03^{\mathrm{a}}$ \\
\hline
\end{tabular}

*Letras diferentes, no sentido horizontal, demonstram diferenças estatisticamente significantes entre os diferentes tempos para os diferentes grupos.

No período inicial de 15 dias, encontraram-se diferenças estatisticamente significantes entre as médias dos valores de infiltração nos grupos IA com IC, IB com IC.

No período de 30 dias, encontraram-se diferenças estatisticamente significantes entre as médias dos valores de infiltração nos grupos IA com IC.

No período de 60 dias, foram encontradas diferenças estatisticamente significantes entre as médias dos valores de infiltração entre os grupos IC e II. 
A análise dos dados, permitiu realizar uma interação entre os cimentos estudados em função dos diferentes tempos (FIGURA 3), sendo possível observar que:

1 - Grupo IA (AH Plus + IRM), apresentou as maiores médias de filtração, tanto após 15 dias, quanto após 30 e 60 dias, sempre de forma crescente, porém sem apresentar diferenças estatisticamente significantes nos seus valores;

2 - Grupo IB (AH Plus + Adper Scothbond Multi Purpose Plus) apresentou médias baixas de filtração no período inicial de 15 dias, sofrendo um aumento não significante na segunda medição e terceiras medições;

3 - Grupo IC (AH Plus + Adper Single Bond 2) foi o que apresentou as menores médias de filtração, sendo bem pequena na medição inicial, aumentando de forma significante no período de 30 dias e 60 dias, sendo neste último bem semelhante ao Grupo IB.

4 - Grupo II (Sistema Epifhany), apresentou médias de filtração baixas no período de 15, aumentando porém, de forma não significante aos 30 dias, havendo um aumento significante dos seus valores iniciais no final do período de 60 dias;

FIGURA 3 - Representação gráfica da interação entre cimentos e tempos estudados.

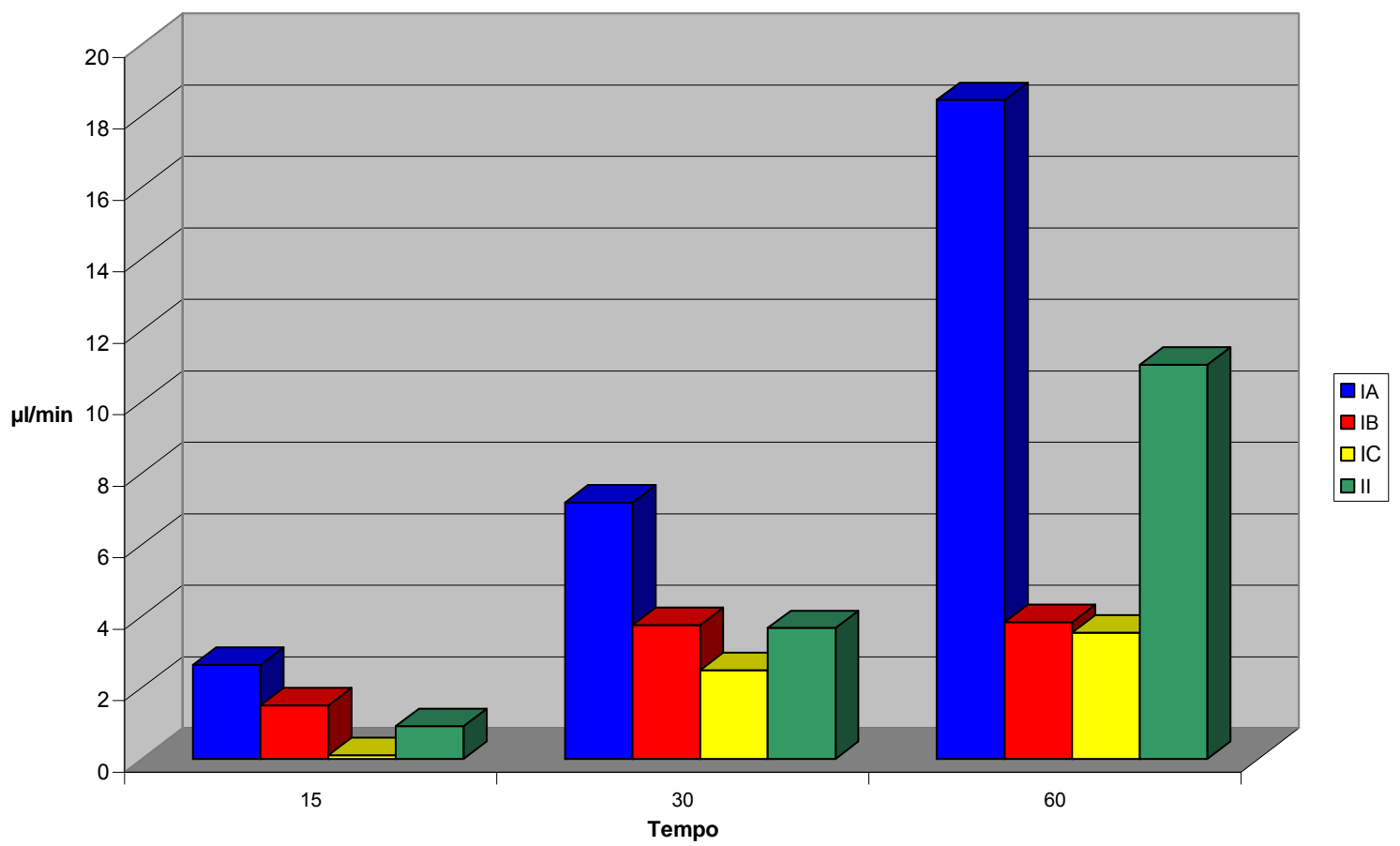




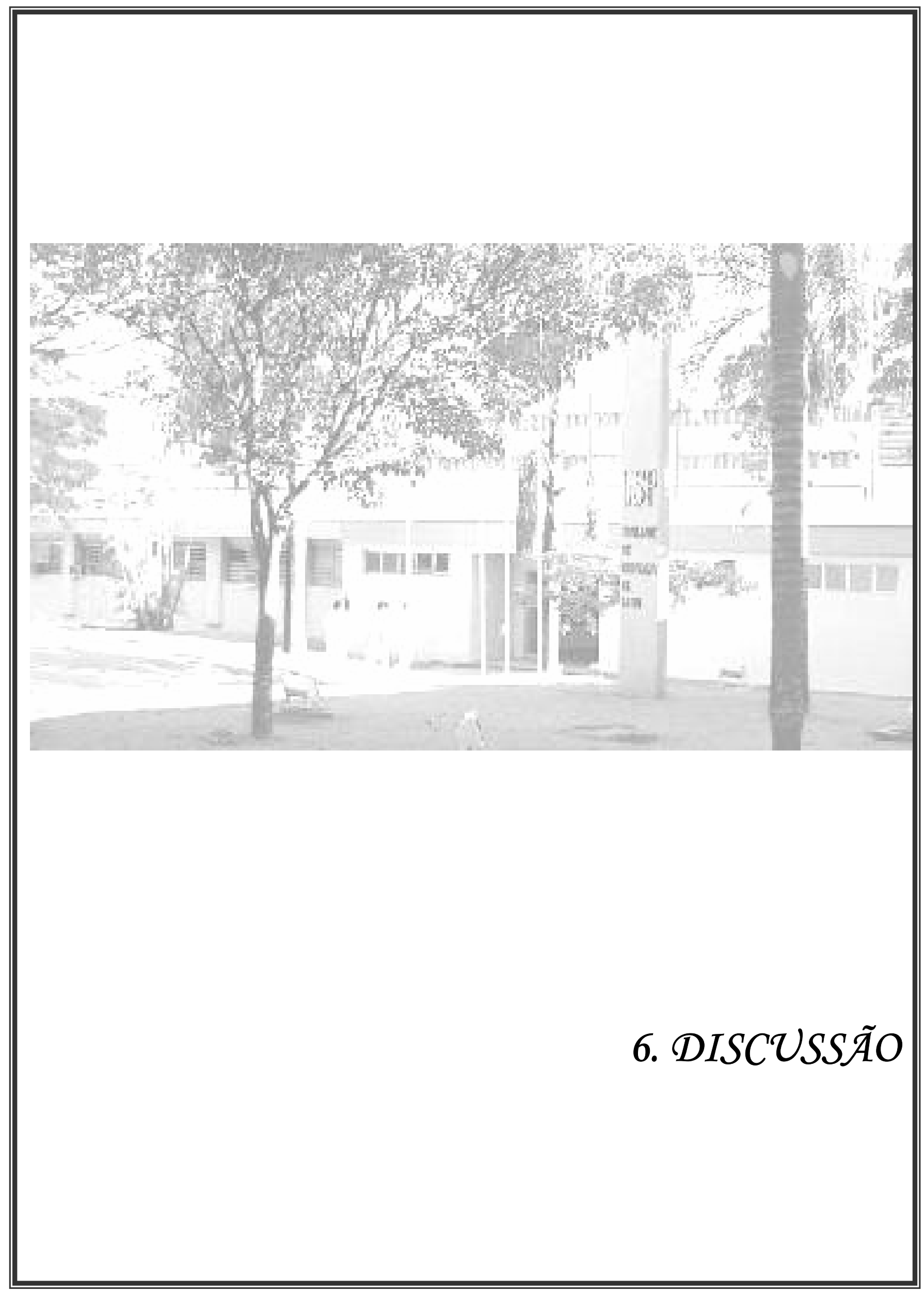




\section{6 - DISCUSSÃO}

Durante muitos anos pôde-se observar na literatura, uma busca incessante por cimentos e técnicas obturadoras que promovessem um selamento hermético dos canais radiculares, fator esse considerado fundamental para o sucesso do tratamento endodôntico, pois obturações deficientes têm sido responsabilizadas como a principal causa de fracassos endodônticos ${ }^{23,25}$. Em conseqüência disso e na busca de um material ideal, surgiram no mercado, novos cimentos obturadores e de diversas composições químicas, como os cimentos à base de resina epóxica, usados de forma tradicional em associação com a guta percha, e mais recentemente um cimento e um cone obturador a base de metacrilato com o objetivo de melhorar suas propriedades adesivas favorecendo a melhor interação possível destes materiais com a dentina e os cones obturadores, e conseqüentemente, proporcionar uma obturação o mais hermética possível. Os cones e cimentos a base de metacrilato, são resinas de dupla polimerização, usados juntamente com um "primer", que prometem formar um "sistema monobloco" e um selamento imediato após a obturação ${ }^{41,48,}$, pela fotoativação deste material no final da obturação, e com isso favorecer o melhor vedamento do canal radicular.

Entretanto, pôde-se também observar nas últimas décadas, uma crescente valorização não só do cimento utilizado na obturação do canal radicular como também do adequado selamento, ou seja, do tratamento e do material que é colocado na cavidade após a conclusão da terapia endodôntica e às propriedades seladoras destes. Este novo enfoque, deve-se a observação dos resultados de trabalhos publicados na literatura, como de VIRE ${ }^{69}$, em 1991, o qual encontrou que 59,4\% dos dentes, endodonticamente tratados, extraídos tinham como motivo a falha das restaurações, contra apenas 8,6\% resultantes de falhas ocorridas no próprio tratamento endodôntico e 0 remanescente, ou seja, 32\% tinham problemas periodontais como causa das falhas.

A importância do selamento adequado durante e após o tratamento endodôntico, também foi reforçada por MAGURA et al. ${ }^{28}$, em 1991, ao encontrarem em canais tratados de dentes extraídos e expostos ao meio bucal, 
num período de três meses, uma intensa penetração de saliva, considerada clinicamente significante; e ao sugerirem conseqüentemente que nestes casos, de dentes com canais obturados, mas não selados adequadamente, eles devem ser retratados se ficarem expostos à cavidade bucal por mais de 3 meses.

Cinqüenta por cento dos dentes com canais tratados, e não selados, quando expostos à bactérias, tiveram suas raízes contaminadas após 19 dias, segundo TORABINEJAD, et al. ${ }^{62}$. Outros estudos apresentaram resultados mais alarmantes ao relatar que a infiltração coronária em dentes não selados e com canais tratados, pode ocorrer num tempo muito curto, de três dias ${ }^{50}$.

Em 2004, ainda visando reforçar a importância do adequado selamento coronário, pode-se citar o estudo de SALEHRABI; ROTSTEIN ${ }^{41}$, em que se avaliaram as possíveis causas de insucessos do tratamento endodôntico, de forma retrospectiva, em 1.462,936 dentes tratados endodonticamente de 1.126,288 pacientes, distribuídos em 50 cidades dos EUA, num período de 8 anos, e a análise dos dentes extraídos revelou que 85\% não tinham cobertura coronária completa.

SWANSON et al. ${ }^{52}$, em 1987, questionaram se essa contaminação via coroa, seria diferente, quando se variam os materiais obturadores. Foram avaliados então canais obturados com Sealapex, Roth's e AH 26 e diferenças estatisticamente significantes, foram encontradas para o grupo do $\mathrm{AH} 26$, que apresentou menor índice de infiltração em relação aos dois outros cimentos testados que, entretanto, não apresentaram diferenças entre si. Provavelmente isto ocorreu por esses materiais possuírem propriedades adesivas diferentes em função das suas composições químicas, ressaltando que a escolha do material obturador pode interferir no sucesso desse selamento.

Estes estudos levam o autor do presente trabalho a questionar o que pode ser feito clinicamente para se garantir a longevidade do tratamento endodôntico, desde que é claro, ele seja realizado de forma criteriosa em todas as suas fases.

No Brasil como em muitos outros países, infelizmente em função do alto custo do tratamento odontológico, muitas vezes pode-se observar que há uma demora excessiva entre o período final do tratamento endodôntico e o momento em que se realiza a restauração definitiva, o que é preocupante ao 
considerarmos as observações anteriores, de que a infiltração coronária é considerada como causa mais freqüente do insucesso deste tratamento 28,41,43,61. Fatos como esses nos levam a concordar e reforçar a importância do chamado selamento imediato pós-endodontia, em que um material restaurador definitivo ou temporário, é colocado intracanal imediatamente após o tratamento, e que vem sendo amplamente discutido e estudado por inúmeros autores nos últimos anos a $^{1,4,16,29,37,60,70,74,79}$ e considerado um reforço a mais, ou seja, uma barreira secundária, cujo objetivo é garantir o sucesso do tratamento endodôntico, não só no período de espera da restauração definitiva, quanto após esta.

Vários materiais temporários têm sido usados, para selar o acesso ao canal radicular entre as sessões ou após o término do tratamento até a realização da restauração definitiva ${ }^{7}$, mas estudos relatam resultados contraditórios sobre a habilidade de selamento desses. (Uranga et al 1999, bobotis 1989)

Em função disso, vários autores como SCWHARTZ; FRANSMAN ${ }^{48}$, em 2005, ressaltam a extrema importância para a longevidade do tratamento endodôntico o tratamento restaurador que é dado a esses dentes, ressaltando características das estruturas dentárias e dos materiais restauradores, com ênfase na escolha desses elementos, no adequado procedimento clínico e no uso de adesivos dentinários. Segundo os autores, o uso desses materiais tem aspecto único e importante para os endodontistas, considerando-se que as falhas nos tratamentos endodônticos, ocorrem por microinfiltrações nas restaurações definitivas ou nas temporárias, sendo que os materiais temporários têm maior tendência à infiltração que os permanentes. Diversos procedimentos têm sido propostos na literatura, como a utilização de materiais nos orifícios dos canais, formando uma barreira, visando uma proteção adicional a essa microinfiltração. Materiais como civ, óxido de zinco e eugenol, MTA e materiais resinosos, colocados numa espessura de $3 \mathrm{~mm}$ ou mais, têm sido preconizados e avaliados. 


\section{1 - Discussão da metodologia empregada}

Como foi dito anteriormente a adesividade é uma propriedade muito importante para os materiais obturadores de canais radiculares ${ }^{13,17,36,47,56,57,65}$ e é definida como a força de atração entre as moléculas ou átomos de duas superfícies em contato íntimo ${ }^{16}$. Subtende-se que um material com uma boa propriedade adesiva seja capaz de evitar a microinfiltração. Segundo TAYLOR; $\mathrm{LINCH}^{58}$, essa passagem de bactérias, fluídos moléculas e íons, entre a parede da cavidade e o material restaurador/obturador aplicado a ela, além de permitir a manutenção de um processo infeccioso, atuaria degradando tecido sadio.

As propriedades adesivas dos materiais são freqüentemente avaliadas através de testes de resistência adesiva e de testes de microinfiltrações, feitos via apical ou coronária. A resistência adesiva se refere à força por unidade de área requerida para quebrar a adesão entre o material adesivo e a dentina, usualmente descrita em MPa (mega pascal). Os testes de microinfiltrações, no caso da endodontia, têm maior aplicabilidade que os de resistência ${ }^{47}$, no entanto, não exsite uma padronização desses métodos e a literatura apresenta uma elevada variabilidade destes testes ${ }^{75}$.

O método de filtração de fluído tem sido recomendado pela sua facilidade de comparação e reprodução ${ }^{75}$. Esse método foi inicialmente descrito por DERKSON et al. ${ }^{15}$, 1986, para avaliar a permeabilidade dentinária e posteriormente adaptado por WU; WESSELINK ${ }^{75}$, em 1993, para testes de infiltrações em endodontia e tem sido descrito, pelos autores, como mais sensível que os demais métodos por permitir quantificar de forma não destrutiva a infiltração em longo prazo.

Alguns autores questionam que, essa variabilidade de métodos, dificulta a confiabilidade dos estudos, já que não há uma padronização, sendo muitos resultados contraditórios ${ }^{7,73,76,78}$. Até recentemente, o método de penetração de corantes era o mais utilizado, este, porém, é um método qualitativo, envolve a destruição dos espécimes, e não fornece informação sobre a qualidade do selamento em longo prazo ${ }^{77,78}$.

A diversidade de estudos gera grande variabilidade dos resultados, que estudos com corantes e isótopos são difíceis para interpretar e quantificar os dados por serem subjetivos; a vantagem de filtração de fluído ser 
longitudinal e não precisar seccionar os espécimes² ${ }^{2}$.

A comparação de dois métodos qualitativos clássicos de infiltração, 0 de penetração de corantes e o de dissolução de corantes, com o novo método quantitativo, de filtração de fluído, na determinação do selamento apical foi feita por CAMPS; PASHLEY ${ }^{9}$, em 2003, e observaram que: o método de filtração e o de corantes mostraram valores de infiltração significantemente diferentes dos obtidos pelo método de penetração. Os autores concluiram que, o método de penetração possui limitações; que o de dissolução apresentou resultados semelhantes com o de filtração, demonstrando pobre correlação entre os estudos de infiltração usando a técnica de penetração de corantes com os que utilizam o método de filtração de fluído. Ressaltaram também, que os resultados podem ser influenciados pelas variações entre os grupos, devido as variáveis não facilmente controláveis, como espessura de lama dentinária, de túbulos dentinários, quantidade de cimento obturador e guta percha, distribuição destes no canal e erros operatórios de mensuração no sistema, e que é necessário minimizar essas variáveis.

O método de infiltração também foi considerado por WU; WESSELING ${ }^{77}$ em 1993, como um método cujos resultados apresentam uma alta variabilidade, pois produzem resultados semiquantitativos, como nos métodos mais comuns, como uso de corantes e radioisótopos, usados em 82\% dos estudos, onde os resultados são medidos de forma linear, através da penetração ao longo dos canais radiculares. Além disso, o tempo de imersão, o tipo de imersão, a presença ou ausência de lama dentinária, a realização da ciclagem térmica, a variabilidade do operador também são fatores responsáveis por essa variação dos resultados. Observam ainda que nos estudos com corantes, bactérias, radioisótopos ou outras substâncias, moléculas pequenas, como a água, podem infiltrar mais que partículas grandes, como bactérias que, entretanto, têm subprodutos com partículas pequenas. Que os gaps entre o material obturador e as paredes do canal, também são fatores que podem dificultar o controle da variabilidade no método, pois podem conter ar ou líquido, o que promove a passagem das substâncias de forma diferente. Consideram importante ainda se os dados são quantitativos ou não, o tamanho da amostra, tamanho das moléculas das substâncias usadas, a relação entre os estudos in vitro com resultados in vivo; e ressalta 
ainda que, provavelmente, a avaliação da infiltração coroa-ápice tem maior significado clínico que a infiltração ápice-coroa.

O método de filtração de fluído foi considerado, mais sensível quando comparado com o de traços de prata, ao se avaliar a infiltração coronária de dentes restaurados com sistemas adesivos e resinas compostas e com civ, porém, sem diferenças estatisticamente significantes com os resultados obtidos pelo outro método ${ }^{78}$.

A sensibilidade do método de filtração pode ser regulada pela alteração da pressão, que pode ser expressa em cm/ $\mathrm{H}_{2} \mathrm{O}, \mathrm{psi}, \mathrm{KPa}$ ou $\mathrm{Kgf} / \mathrm{cm}^{2}$. Cada $50 \mathrm{KPa}$, equivale a $0.50 \mathrm{Kgf} / \mathrm{cm}^{2}$, a $1020 \mathrm{~cm} / \mathrm{H}_{2} \mathrm{O}$ e a 7.25 psi. No presente estudo, o método de filtração foi usado numa pressão de 7.4 psi, baseando-se no trabalho de YOUGSON et al. ${ }^{78}$, em 1999, onde ressaltam que qualquer pressão usada no dispositivo de filtração de fluído, desde que maior que a pressão fisiológica pulpar, que é de $15 \mathrm{~cm} / \mathrm{H}_{2} \mathrm{O},(0,0014 \mathrm{MPa})$, é capaz de promover um índice de infiltração nos materiais. Essa padronização permite uma maior confiabilidade dos resultados.

A utilização de diferentes períodos de tempo e pressões que na literatura variam de 10 a 20 psi nos testes de filtração de fluídos pode afetar os resultados: a quantidade de filtração diminuiu com o aumento do tempo, mas inversalmente, uma infiltração mais alta, pode ser obtida com uma alta pressão. O diâmetro do tubo e tamanho da bolha, introduzida no dispositivo de filtração, também podem influenciar nos resultados, sendo necessário o estabelecimento de um protocolo para que se possam comparar os resultados ${ }^{39}$.

No presente trabalho optou-se por empregar dentes humanos unirradiculares, pois em um estudo in vitro, empregando infiltração com corantes, em molares, SAUNDERS; SAUNDERS ${ }^{45}$, em 1990, encontrou altos valores de infiltração para materiais com civ, civ modificado por resina, guta percha e amálgam e o os autores acreditam que esse grau de infiltração pode ser devido à alta incidência de comunicação entre a câmara pulpar e a região de furca nos dentes multirradiculares, fator esse que pode influenciar nos resultados.

Os dentes depois de devida limpeza dos debris orgânicos foram cortados na porção coronária (junção amelo cementária) e apical, com o objetivo de padronizar o comprimento em 10mm, já que WU; WESSELING ${ }^{75}$, 
em 1993, enfatizaram que, para maior confiabilidade dos resultados, nos estudos de infiltração, em dentes tratados endodonticamente, é necessário se observar outros tópicos como: redução da variação do comprimento e anatomia dos canais radiculares e diâmetro final do forame apical.

Após a instrumentação manual pela técnica escalonada regressiva, a remoção da smear layer foi feita com EDTA a 17\%, com a finalidade de melhorar a adaptação e ou adesão dos materiais obturadores às paredes do canal. Para o mecanismo de adesão dos cimentos obturadores resinosos ocorrer de forma efetiva, as paredes do canal radicular devem estar totalmente limpas e livres de debris orgânicos, o que muitas vezes não ocorre somente através da instrumentação e irrigação desses canais ${ }^{487}$. A importância da remoção da smear layer na adesão dos cimentos obturadores, também foi verificada por GARCIA-GODOY et al. ${ }^{17}$, em 2005.

Assim como a adesão, outros fatores podem ser decisivos na infiltração coronária, como remoção inadequada da lama dentinária, presença de canais acessórios no assoalho da câmara pulpar de dentes multirradiculares, e restaurações posteriores que envolvam a colocação de pinos intra-radiculares ${ }^{46,54}$. O EDTA tem sido o agente irrigador mais utilizado, e a formação de uma fina camada híbrida foi observada quando o mesmo é usado com irrigador final, mesmo na ausência de adesivo ${ }^{17}$. A irrigação com EDTA, também reduz linearmente e volumetricamente a micropenetração coronária, aumentando conseqüentemente o sucesso deste tratamento ${ }^{68}$.

Uma tendência a maior infiltração quando se utilizou apenas o $\mathrm{NaOCl}$ como irrigante final, foi encontrada por STRATTON et al. ${ }^{55}$, em 2006, num estudo em que se variaram as substâncias irrigadoras, $\mathrm{NaOCl}$ a 5,25\%, Clorexidina a $0,012 \%$ e a $2 \%$, em canais obturados com os mesmos cimentos.

ÇOBANKARA et al. $^{13}$, em 2004, propuseram-se a avaliar se a presença da camada de lama dentinária tinha influência ou não, na infiltração coronária e apical de dentes tratados endodonticamente. Utilizou-se para irrigação somente $10 \mathrm{ml}$ de $\mathrm{NaOCl}$ a 5,25\%, e quando buscava a remoção da lama dentinária, irrigou-se com $10 \mathrm{ml}$ de EDTA, antes do hipoclorito. A presença de lama dentinária, em ambos grupos de cimentos, AH Plus e Roekoseal, promoveu significantemente mais infiltração apical e coronária; nenhuma diferença estatisticamente significante foi encontrada entre os dois 
cimentos, entretanto a infiltração apical foi maior que a coronária em ambos os cimentos.

Outros fatores como a termoplastificação da guta percha, a remoção da smear layer, a regularização das paredes dentinárias no canal radicular, permite uma maior adaptação do material obturador (cimento + guta), assim como a utilização do ataque ácido mais materiais adesivos na restauração coronária, melhoram o selamento nesta região ${ }^{14}$.

No presente estudo, objetivamos avaliar a capacidade de selamento coroa-ápice do material restaurador provisório IRM e de dois sistemas adesivos, o Adper Scothbond Multi Purpose Plus, um convencional de três passos, ácido, primer e adesivo e o Adper Single Bond 2, um simplificado de dois passos, ácido e primer + adesivo, usados como seladores imediatos em canais obturados com guta percha e o tradicional cimento AH Plus, à base de resina epóxica e as propriedades seladoras do novo Sistema Epiphany composto por um primer um cimento e cone obturador à base de metacrilato. A preocupação neste tipo de avaliação é crescente nos últimos anos, pois é evidente a recontaminação de canais pós-tratamento endodôntico ${ }^{28,62,69}$.

O Grupo IA, apresenta o material IRM, associado com o cimento AH Plus e guta percha, que são materiais empregados na rotina endodôntica e amplamente discutidos na literatura.

Já nos Grupos IB e IC, os canais foram obturados da mesma forma, ou seja, guta precha + AH Plus, mas se utilizou como materiais seladores dois sistemas adesivos, um convencional de três passos e um simplificado de dois passos, de um mesmo fabricante, bastante usados no nosso país e de fácil obtenção no mercado odontológico. Esses sistemas foram aplicados numa espessura de $4 \mathrm{~mm}$, baseando-se para isso no estudo de ZAIA et al. ${ }^{79}$, em que uma gota de material proporciona uma camada de aproximadamente $2 \mathrm{~mm}$ de espessura, quando ficava insuficiente, mais uma gota do material era dispensada e fotopolimerizada por mais 20 segundos, visando a padronização da espessura da barreira.

No Grupo II, os canais foram obturados com o Sistema Epiphany, sendo o mesmo fotoativado no final da obturação, sem colocação de nenhum material selador secundário, pois o objetivo era verificar sua capacidade "per si“ de impedir a infiltração no sentido coroa-ápice. Esse material tem sido 
considerado promissor pelo fabricante, principalmente por suas características adesivas, sempre com o intuíto de se obter a melhor a adaptação do material obturador, cimento e cone, entre si e as paredes do canal radicular. $\mathrm{Na}$ literatura diversos trabalhos têm sido feitos com esse novo material, visando testar suas propriedades físicas, químicas e biológicas ${ }^{5,38,55,56,57,72}$.

Esses materiais foram colocados no terço coronário do canal radicular, após instrumentação e preparo de aproximadamente $4 \mathrm{~mm}$ dessa porção com brocas de Gattes Glidden $n^{0}-3$ e 4 , visando padronizar o máximo possível à espessura dos materiais testados.

Uma espessura mínima de 2,5 e máxima de $4 \mathrm{~mm}$ é recomendada por TURNER et al. ${ }^{66}$, em 1990, para prevenção da infiltração marginal. É necessário, entretanto, aliada a essa observação avaliar clinicamente a espessura possível, baseando-se no remanescente dental e posterior restauração definitiva. Entretanto, JENKINS et al. ${ }^{24}$, em 2006, avaliaram diferentes espessuras de barreiras, de 1 a $4 \mathrm{~mm}$, e não observaram diferenças significantes nos valores de selamento que elas proporcionaram.

Quanto à localização da barreira secundária, ou seja, se é colocada $2 \mathrm{~mm}$ do assoalho da câmara pulpar ou dentro do orifício do canal radicular. Isso não parece ter influência na habilidade de vedamento do material selador. Porém, uma barreira mais espessa e dentro do orifício do canal pode ser mais efetiva no caso da presença de canais acessórios no terço coronário do canal radicular $^{70}$.

Deve-se observar também, se os materiais restauradores usados na obturação dos canais radiculares, podem interferir nas propriedades adesivas e ou seladoras dessa barreira, como o eugenol, $\mathrm{NaOCl}$, clorofórmio e outros, sendo fundamental portanto, o conhecimento de tais particularidades para evitar problemas clínicos nas restaurações ${ }^{2}$. Por exemplo, para o sistema adesivo não ter sua polimerização prejudicada pelo óxido de zinco eugenol, presente em alguns cimentos obturadores, deve-se limpar a cavidade após a obturação, e deve ser aplicado o sistema adesivo, segundo o fabricante, mas em duas camadas, para se obter espessura suficiente ${ }^{74}$.

No presente estudo, a porção coronária do canal radicular foi limpa com álcool absoluto, não havendo preocupação com a influência do eugenol, pois se utilizou na obturação um cimento à base de resina epóxica. 


\section{2 - Discussão dos resultados}

Os quatro grupos foram avaliados comparativamente quanto à capacidade de filtração, através do sistema de transporte de fluído, nos períodos de 15, 30 e 60 dias.

Essas avaliações foram realizadas com o intuito de verificar a capacidade de selamento desses materiais, pois através do maior ou menor deslocamento da bolha, subentende-se que os materiais são efetivos ou não, neste sentido.

No período de 15 dias, observaram-se baixos índices de filtrações em todos os grupos, principalmente nos que se usaram materiais à base de resina, de acordo com GALVAN et al. ${ }^{16}$, em 2001, que citam que de uma forma geral, esses materiais promovem sempre um bom selamento inicial. Os bons resultados apresentados, neste estudo e neste período inicial de 15 dias, pelo Grupo IC e IB, pode ser explicado também pelo fato dos agentes adesivos de uma forma geral serem bons seladores, além de serem translúcidos e facilitarem a remoção da guta percha, diminuindo o risco de perfurações no caso de colocação de pinos ou retratamentos ${ }^{74}$. O fato do Grupo IB apesar de apresentar valores baixos de filtração, mas significantemente maiores que os do Grupo IC, neste período, pode ser relacionado à diferente composição química desses materiais, sendo um simplificado de dois passos e o outro convencional de três passos. LEONARDO et al. ${ }^{25}$, em 1996, consideram o Scothbond um agente adesivo que possui alta resistência adesiva, boa habilidade de penetração nos túbulos dentinários e, portanto, com grande tendência de resistir à infiltração.

O Grupo II, do Sistema Epiphany, apesar de não possuir nenhum material selador adicional, como nos demais, comportou-se muito bem nesta fase inicial, sem apresentar diferenças significantes com os demais grupos, porém, com valores de filtração menores que os grupos IA e que o grupo IB, e maiores que o IC.

O grupo IA ao contrário dos demais, já na fase inicial, de 15 dias, mostrou valores de filtrações maiores, sendo significantemente maior que os do 
Grupo IC. Conseqüentemente, o cimento AH Plus + guta percha, denotam permitir também infiltrações, quando do emprego desta metodologia, corroborando com os achados de TUNGA; BODRUMLU ${ }^{65}, 2006$. A guta percha, usada com ou sem cimento, promove um pobre selamento coronário, por não aderir às paredes do canal, não sendo capaz de evitar a microinfiltração coronária se o dente não for restaurado satisfatoriamente ${ }^{41}$. A existência de espaços vazios e traços de prata em canais obturados com guta percha e Endorez, tanto entre a guta percha e a dentina quanto entre os materiais, foi demonstrada por Tay et al. ${ }^{57}$, em 2005, confirmando que a guta percha não promove um selamento efetivo do canal radicular.

No período de 30 dias, o Grupo IA, comportou-se como esperado, ou seja, o IRM continuou permitindo progressivamente a filtração, continuando maior que os demais grupos, sendo seus valores significantemente maiores que os do Grupo IC. Já o Grupo II, sofreu um aumento significante nos seus valores de filtração, porém mantendo um elevado grau de selamento, muito semelhante ao Grupo IB. Os Grupos IB e IC permitiram neste período, maiores valores de filtrações que na fase anterior, sendo que no IC, o aumento nesses valores foi numericamente maior que no IB. No entanto, exibiram ainda bons valores de selamento.

No último período, de 60 dias, o Grupo II, do Sistema Epiphany, teve um aumento significante dos seus valores de filtração, provavelmente pelo fato desses espécimes não terem tido o selamento secundário com outro material, e por ser um cimento resinoso hidrofílico usado com um primer simplificado, autocondicionante. Os sistemas adesivos simplificados de uma forma geral apresentam-se como membranas permeáveis após a polimerização, resultantes da passagem de água da dentina, mesmo em dentes tratados endodonticamente ${ }^{11}$, que pode afetar posteriormente a polimerização de um cimento resinoso, podendo explicar essa alta média de filtração neste período.

Os grupos IB e IC, entretanto, nesta fase apresentraram-se com um aumento de filtração, significante apenas para o Grupo IC, porém mais baixos que os demais, sendo os valores do Grupo IC significantemente menores quando comparados aos do Grupo II, podendo ainda, serem considerados igualmente efetivos, como nos achados de BELLI et al. ${ }^{4}$, em 2001, em que os sistemas adesivos monstraram elevadas e melhores propriedades de 
selamento que o IRM. Altos valores de infiltrações também foram encontrados na literatura para o IRM, sempre aumentando com o tempo, mostrando assim como os achados deste estudo que seu uso deve ser limitado a períodos curtos 1,7

Os cimentos à base de óxido de zinco e eugenol, como o IRM, têm sido amplamente utilizados por mais de 60 anos como restauração provisória, ou após o tratamento endodôntico ou durante as etapas deste.

No presente estudo o IRM foi o material que obteve as maiores médias de filtração, tanto após 15 dias quanto após 30 e 60, apresentando-se sempre de forma crescente, porém num crescimento não estatisticamente significante. Esses resultados estão de acordo com a maior parte dos trabalhos publicados na literatura em que o IRM apresentou altos valores de infiltrações e um pobre selamento ${ }^{2,4,6,7,12,16,26,60,79,80}$, além de possuírem propriedades mecânicas insuficientes ${ }^{26}$.

O IRM e cimento de policarboxilato apresentaram-se menos efetivos que outros como Cavit, Cavit-G e o TERM, em relação a sua capacidade seladora, e são mais influenciados pelos efeitos da ciclagem térmica, fenômeno comum na cavidade bucal ${ }^{7}$. Esses altos valores de infiltrações encontrados em espécimes restaurados com IRM podem ser devido ao seu preparo (mistura pó+ liquido), sendo encontradas após análise pela SEM, presença de bolhas e espaços vazios ente o cimento e a dentina ${ }^{80}$. Ou ainda, à diluição deste material, pois devido a quelação existente entre as moléculas do eugenol e do óxido de zinco, elas são hidrolizadas na presença de água, sendo responsável pela baixa habilidade de selamento ${ }^{4}$.

Ao contrário dos achados deste estudo, autores como TURNER et al. ${ }^{66}$, em 1990, encontraram no IRM e ZOE baixos valores de microinfiltrações, ao compararem com o Cavit, Cavit G, TERM, IRM e o Fuji II. Porém,TAY et al. em 1988, acreditam que resultados como esse se devam mais às propriedades antimicrobianas deste material, dada a liberação lenta e gradativa do óxido de zinco e eugenol, do que as suas propriedades de selamento e que os diferentes proporcionamentos dos materiais também resultam em diferentes graus de selamento como foi observado em cavidades de classe 1 , e sendo 0 ZOE o material que mais apresentou diferenças estatisticamente significantes nas diferentes proporções. E que, com o passar do tempo, esses materiais 
aumentam o índice de infiltração ${ }^{38}$.

E mais uma vez, ressaltando a importância do fator tempo no selamento com IRM, ZAIA et al. ${ }^{79}$, observou em 2002, em um estudo de infiltração com corante azul de metileno encontraram melhores valores de selamento para o IRM e para o Coltosol, em relação ao Scoth Bond e a um civ, porém, esse resultado pode não ser relevante, pois esses materiais foram observados num período de tempo curto de 7 dias.

Entretanto, o IRM é um material restaurador temporário facilmente encontrado e de custo baixo e que quando bem utilizado, na sua proporção correta e no tempo correto de permanência na cavidade bucal, ou seja, num tempo curto, muitas vezes por ser a única opção do cirurgião dentista, pode ser usado como selador e, portanto, como um recurso a mais na manutenção da logenvidade deste tratamento. GOMES et al. ${ }^{19}$, em 2003 , relatam que o selamento coronário diminui, mas não previne totalmente a infiltração de microrganismos, sendo estatisticamente significante a diferença de infiltração em dentes selados com IRM, e os não selados.

Assim como o IRM, o Kalzinol, um outro material a base de óxido de zinco, avaliado num estudo com testes eletroquímicos, feito por IIM $^{26}$, em 1990, apresentou menor infiltração assim como no Ketac-Fil com condicionamento, seguido do Ketac-Fil sem condicionamento e por fim o Cavit-W. Esse achados podem ser devido a presença do óxido de zinco eugenol no Kalzinol, que possue efeito bactericida, ao método e tempo de teste, que foi de apenas 7 dias. Ao contrário do estudo anterior, TEWARI; TEWARI ${ }^{60}$, em 2002, relatam extensa penetração de corantes em dentes selados com IRM e Calzinol, após os $1^{0}$ e $3^{0}$ dias respectivamente e também atribuem os bons resultados de selamento encontrados em alguns estudos às propriedades antimicrobianas destes, pela presença do eugenol, e não especificamente às suas capacidades de selamento.

Neste estudo, os espécimens do grupo IB, em que se utilizou 0 material selador Adper Scothbond Multi Purpose Plus, apresentaram médias de infiltrações baixas no período inicial, sofrendo um leve aumento após 30 dias e mantendo-se praticamente estável até o período final. No grupo IC, em que se utilizou o Adper Single Bond 2, as menores médias de filtrações foram encontradas em todos os períodos, porém foi o material que apresentou 
ou seja, uma segunda linha de defesa para o orifício do canal radicular: os civs modificados por resina, que apresentam como desvantagem a dificuldade de visualização da guta percha mais cimento no caso de um retratamento; os cimentos resinosos como o C\&B Metabond, que podem ser usados com o pó de polimetilmetacrilato, ficando mais transparentes, facilitando a visualização da guta percha no interior do canal e agentes adesivos como o Clearfil SE Bond $^{34}$.

Materiais restauradores temporários e sistemas adesivos como; New Bond (adesivo) + Clearfil (adesivo); Grupo II, Optibond Solo (adesivo) + CoreRestore (resina); Grupo III, Ketac Fil (civ); Grupo IV, IRM (cimento de óxido de zinco eugenol reforçado), foram também testados através de um teste de infiltração bacteriana e nenhuma diferença significante de infiltração foi encontrada entre os grupos no final dos 12 meses, sendo que no início do experimento o IRM apresentou a pior performance e o Clearfil o material que nos dozes meses apresentou melhores resultados ${ }^{3}$, assim como nos achados do presente estudo.

Já os autores, BELLI et al. ${ }^{4}$, em 2001, encontraram ao comparar a capacidade de selamento de quatro materiais: C\&B Metabond + pó transparente de polimetil metacrilato, sistema adesivo One-Step + resina microhíbrida de baixa viscosidade, Clearfill SE Bond Primer + resina composta fotopolimerizável transparente e IRM, maiores valores de infiltração para o IRM, sem haver diferenças estatisticamente ente os demais grupos, porém ressaltam, que esses adesivos não foram submetidos a nenhum esforço, que o estudo foi por um período curto (1 mês), e que no uso clínico devem ser protegidos por materiais como amálgama, resina composta ou civ. Consideram que a colocação de uma resina diretamente no orifício, dificulta a remoção num retratamento, por isso os adesivos foram apenas recobertos com resinas transparentes, quando não possuiam uma espessura de 10 $\mu \mathrm{m}$. O agente adesivo dentinário (Clearfill Liner Bond 2V) foi também testado e usado como barreira coronária por WOLANEK et al. ${ }^{74}$, e bons resultados de selamento foram obtidos; os autores ressaltam o fato desse material ser transparente o que facilita a visualização da guta percha caso necessite de retratamento ou colocação de pinos.

Assim como os achados anteriores, GALVAN JUNIOR, et al. ${ }^{16}$, 
em 2002, encontraram melhores valores de selamento materiais adesivos como C\&B Metabond e Amalgamabond usados juntamente com um pó transparente de polimetilmetacrilato, One-Step Adesivo + resina composta, do que para o IRM, principalmente após 1 mês, considerando o C\&B Metabond e Amalgamabond de mais fácil uso, por serem fotopolimerizáveis e não necessitarem de resina adicional. O menor selamento da Palfique, após 7 dias, pode ser devido à expansão (absorção de água), porém sua transparência pode facilitar a localização da guta percha. Convém ressaltar que o óxido de zinco eugenol, presente em alguns cimentos obturadores pode interferir na polimerização desses materiais.

A eficácia de selamento coronário de barreiras realizadas com dois materiais o compômero, o Principle e o cimento resinoso C\&B Metabond, foi avaliada por WELLS, et al. ${ }^{70}$, em 2002, sendo as barreiras realizadas com 2 $\mathrm{mm}$ de espessura colocadas sobre a câmara pulpar ou dentro (na entrada) dos canais radiculares, e o Principle foi mais fácil de ser usado assim como o selamento na entrada da câmara. Segundo os autores, compômeros são materiais bem indicados para barreira coronária, por não precisarem de primers nem de agentes adesivos, podendo ser químicos ou auto polimerizáveis, e ressaltam que a espessura da barreira pode interferir na posterior restauração. O selamento inicial do C\&B foi maior na primeira semana, provavelmente devido à absorção de água do compômero ser maior neste período, causando um melhor selamento.

A força de adesão inicial da resina à dentina é maior que a do esmalte (40-50MPa X 25-35MPa), porém essa tende a diminuir com o tempo, em função da absorção de água, pela resina e pela degradação do colágeno na camada híbrida, enquanto que a do esmalte tende a se manter estável, desde que bem condicionado com ácido fosfórico a 37\% e bem lavado. Porém, mesmo assim, PASHLEY ${ }^{34}$, considera que o uso de cimentos resinosos para selar o acesso coronário após o tratamento endodôntico é muito mais efetivo que o uso de qualquer outro material temporário, desde que toda margem superior do esmalte for bem condicionada.

Assim como os achados deste estudo, em que os adesivos apresentaram boa habilidade de selamento, porém diminuindo com o tempo, OZTURK et al. ${ }^{33}$, em 2004, avaliaram a capacidade de selamento de cinco 
sistemas adesivos, observaram diferenças significantes de selamento entre eles nos diferentes períodos, e todos valores também diminuíram com o tempo (um mês), principalmente o Scoth Bond Multi Purpose Plus e o EBS-Multi, quando nenhum deles apresentou diferenças significantes entre si. Através da avaliação pela SEM (aumento de 550x a 1500x), não encontraram formação de camada híbrida entre a dentina e os adesivos, irrigando com $\mathrm{NaOCl}$ apenas, e ressaltam pode ser devido à estrutura dentinária da câmara pulpar ser mais complicada, incluindo formação de pré-dentina, dentina fisiológica secundária e terciária. Acreditam que esses resultados e a maior infiltração inicial encontrada, após 24 horas, pode ter sido devido ao fator $\mathrm{C}$ de configuração da câmara pulpar, formato em caixa, que conseqüentemente promoveu maior contração de polimerização dos adesivos.

Outro aspecto a ser considerado é que todo material resinoso ao ser polimerizado contrai, promovendo um estresse na interface denterestauração e no caso dos materiais fotopolimerizáveis, essa tensão de contração ocorre segundos após a irradiação. Esse estresse pode promover a ruptura da ligação do sistema adesivo/ paredes cavitárias, resultando numa microinfiltração, quando a força de contração do material é maior que a resistência adesiva deste. Nenhum sistema adesivo previne o desenvolvimento de gaps na interface dente/restauração, 10 minutos após sua colocação, mas com o tempo esses gaps diminuem pela expansão higroscópica do material ${ }^{41}$.

No caso do canal radicular ser obturado por um cimento endodôntico à base de resina, deve-se levar em consideração, portanto, que assim como acontece com os materiais restauradores resinosos, após a fotopolimerização e conversão de monômeros resinosos em polímeros, vai haver conseqüente contração e estresse, e esse cimento a base de resina também vai contrair, formar gaps e possibilitar futuras infiltrações. Esse estresse de contração é maior em superfícies fechadas, dependendo da conformação da cavidade, o chamado fator C que é calculado dividindo-se quantas superfícies são aderidas pelas livres. Quanto maior o fator C, maior o estresse de contração. No caso do canal radicular esse fator é alto, tendo-se como superfície livre apenas a abertura do canal, e isso pode ser um fator limitante do uso de materiais adesivos nesta região ${ }^{34}$.

Neste trabalho, no Grupo II, em que os espécimes foram obturados 
somente com o Sistema Epiphany, pôde-se observar nos períodos de 15, 30 e 60 dias, que essas médias aumentaram significantemente, ficando maiores que os demais materiais, com exceção do Grupo IA. Bons valores de selamentos iniciais para o Sistema Epiphany também foram encontrados por TUNGA; BRODUMLU ${ }^{64}$, 2006. Podem-se justificar esses achados pela opnião de PASHLEY ${ }^{34}$ que, em longo prazo, não se sabe ainda o comportamento do Resilon que apesar de ser um poliéster de baixa degradação em água, praticamente nula, de $\mathrm{pH}$ extremamente baixo e muito hidrofóbico pode, entretanto, ter seu índice de degradação acentuado por enzimas como a esterase, presente em adesivos a base de éster, células humanas e fluídos corporais que podem por sua vez podem atingir o canal radicular. Deve-se considerar também que nesse grupo não foi utilizado nenhum material selador como barreira secundária, pois se tinha como um dos objetivos neste trabalho, avaliar se esse novo Sistema obturador promove realmente um selamento coronário imediato ao ser fotoativado no final da obturação, como é citado pelos fabricantes, porém sabe-se que, apenas a porção cervical desse material vai ser fotoativado, e que a porção média e apical vão sofrer a polimerização química.

O Sistema Epiphany, além de possuir um cone e um cimento obturador à base de metacrilato, possui um sistema adesivo, simplificado, considerado de dois passos, em que o primer acidificado não remove a smear layer, apenas a incorpora.

Uma das recentes tendências na endodontia tem sido 0 desenvolvimento de materiais obturadores adesivos, com o objetivo de obter o melhor selamento coronário e apical. Porém, deve-se levar em consideração que as propriedades e características destes materiais já amplamente discutidas na literatura, são relativas a utilização destes como materiais restauradores, e considerar a necessidade de avaliá-los agora quando utilizados no canal radicular com suas particularidades e características próprias.

Os dentes tratados endodônticamente, apesar de não possuírem a pressão interna pulpar positiva, responsável pela movimentação de água pela dentina coronária, possuem um aumento da permeabilidade na dentina radicular, decorrente da redução de espessura, durante a instrumentação, 
remoção de cimentos, nos casos de retratamentos ou colocação de pinos ${ }^{41}$.

O efeito adesivo desses materiais no ambiente do sistema de canais radiculares é um desafio, devido a anatomia, limitações, características da dentina e propriedades físicas e mecânicas desses materiais adesivos ${ }^{47}$. Porém, Schwartz RS ${ }^{47}$, em 2006, também considera que o uso destes promete uma obturação dos canais de forma mais efetiva e que progressos neste sentido estão sendo obtidos.

O processo adesivo descrito inicialmente por NAKABAYASHI et al. $^{32}$ (1982) pode ser descrito de uma forma simplificada como: a aplicação de um ácido na face dentinária, a lavagem deste e conseqüente remoção da smear layer da dentina superficial, desmineralização desta e exposição da matriz de colágeno. Em seguida, um material resinoso, contendo um líquido volátil, como acetona ou álcool, denominado primer, é então aplicado na superfície desmineralizada, penetrando e transportando o material resinoso nos túbulos dentinários e na matriz de colágeno. O líquido volátil evapora e ficando o material resinoso. Então um material resinoso (adesivo) é aplicado e polimerizado, promove uma superfície hidrofóbica, denominada de camada híbrida, que vai se unir posteriormente ao material restaurador, também com características hidrofóbicas.

No caso do Resilon ele já é um polímero pronto, o que vai contrair é o agente adesivo dual e o primer autocondicionante que são usados em conjunto, e é essa força de contração do adesivo, que pode puxar o cone Resilon e formar gaps entre ele e as paredes do canal, pesquisa futuras são necessárias para avaliar essa possibilidade.

O uso de adesivos convencionais menos permeáveis, como os sistemas adesivos convencionais têm sido considerados como uma alternativa mais racional ${ }^{11}$. Os sistemas adesivos autocondicionantes simplificados, ou de dois passos (ácido e primer + adesivo) ou de passo único (ácido + primer + adesivo) quando aplicados sobre a dentina radicular, como acontece com alguns novos cimentos endodônticos a base de resina, comportam-se da mesma forma que quando aplicados sobre a dentina coronária de dentes vitais, ou seja, como membranas permeáveis, resultando na movimentação de água na dentina radicular de dentes tratados endodonticamente, decorrente do aumento na hidrofilia nesses sistemas, o que pode interferir de forma adversa 
valores significantemente mais diferentes, sendo nos tempos de 15 e 30 dias, de 30 e 60 dias e de 15 e 60 dias.

Essa diferença, apesar dos dois materiais terem sido os que apresentaram as menores médias, pode ser atribuída às diferentes composições desses sistemas adesivos. O Adper Scothbond Multi Purpose Plus, é um sistema adesivo convencional de três passos, ou seja, inicialmente faz-se um ataque ácido com ácido fosfórico a 37\%, aplicação de um primer hidrofílico que se difunde rapidamente nos túbulos dentinários, seguida da aplicação de um adesivo hidrofóbico, de difusão mais lenta. O Adper Single Bond 2, é um sistema adesivo também classificado como convencional, porém simplificado de dois passos, em que após o ataque com ácido fosfórico a 37\%, aplica-se o primer que vem em conjunto com o adesivo, e nessas condições há a predominância das características hidrofílicas na substância. No caso desses sistemas adesivos convencionais o controle da água é, portanto, fundamental para efetiva difusão destes adesivos, não devendo secar em excesso a superfície dentinária.

É fundamental também se levar em consideração fatores como a morfologia, a fisiologia do substrato dentinário e fatores relativos ao paciente, assim como realização correta da técnica, que são determinantes na durabilidade dos procedimentos adesivos.

Vários trabalhos na literatura ${ }^{3,4,15,16,33}$ têm sido realizados com 0 objetivo de testar a capacidade de selamento dos sistemas adesivos quando usados como barreiras secundárias e bons resultados de selamento são reportados, porém assim como neste trabalho, nenhum sistema adesivo foi capaz de prevenir totalmente a filtração de fluídos, pode ser devido à presença de canais formados ao redor dos tags de resina, que criam poros nanométricos na camada híbrida ${ }^{8}$.

Os sistemas adesivos apresentam, após a polimerização, absorção de água e conseqüente expansão higroscópica. Este fato pode aumentar a capacidade do selamento desses materiais ${ }^{10}$. Porém, na cavidade pulpar, deve-se considerar que a habilidade para criar uma alta qualidade de adesão é mais complicada, pela presença de pré-dentina, dentina secundária fisiológica e dentina terciária ${ }^{33}$.

Vários materiais podem ser usados em um selamento secundário, 
na polimerização desses cimentos (auto/dual). O stress de contração do cimento resinoso aliado à alta hidrofilia desses sistemas adesivos simplificados pode contribuir para a degradação da adesão entre a dentina intra-radicular e o adesivo, favorecendo a infiltração coronária. 


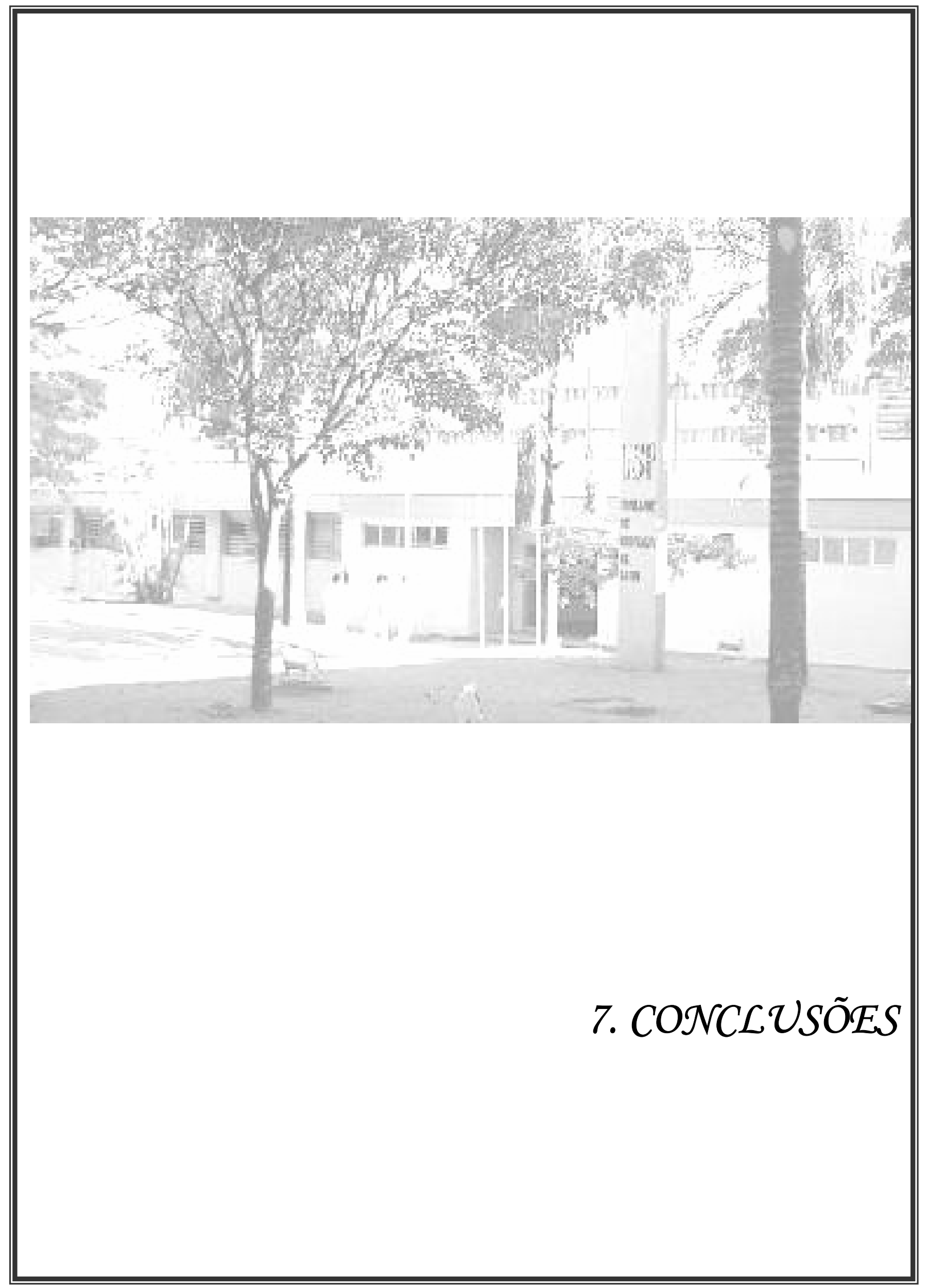




\section{7- CONCLUSÕES}

Considerando as condições experimentais, após a avaliação da literatura e dos resultados obtidos, pôde-se concluir que:

- todos os materiais testados permitiram a infiltração coronária;

- a hipótese nula foi rejeitada e os materiais apresentaram diferenças estatisticamente significantes, nos seus valores de filtração, nos períodos de 15, 30 e 60 dias, sendo encontradas diferenças entre os Grupos IA e IC, nos períodos de 15 e 30 dias; entre os Grupos IB e IC no período de 15 dias e entre os Grupos IC e II, no período de 60 dias. 


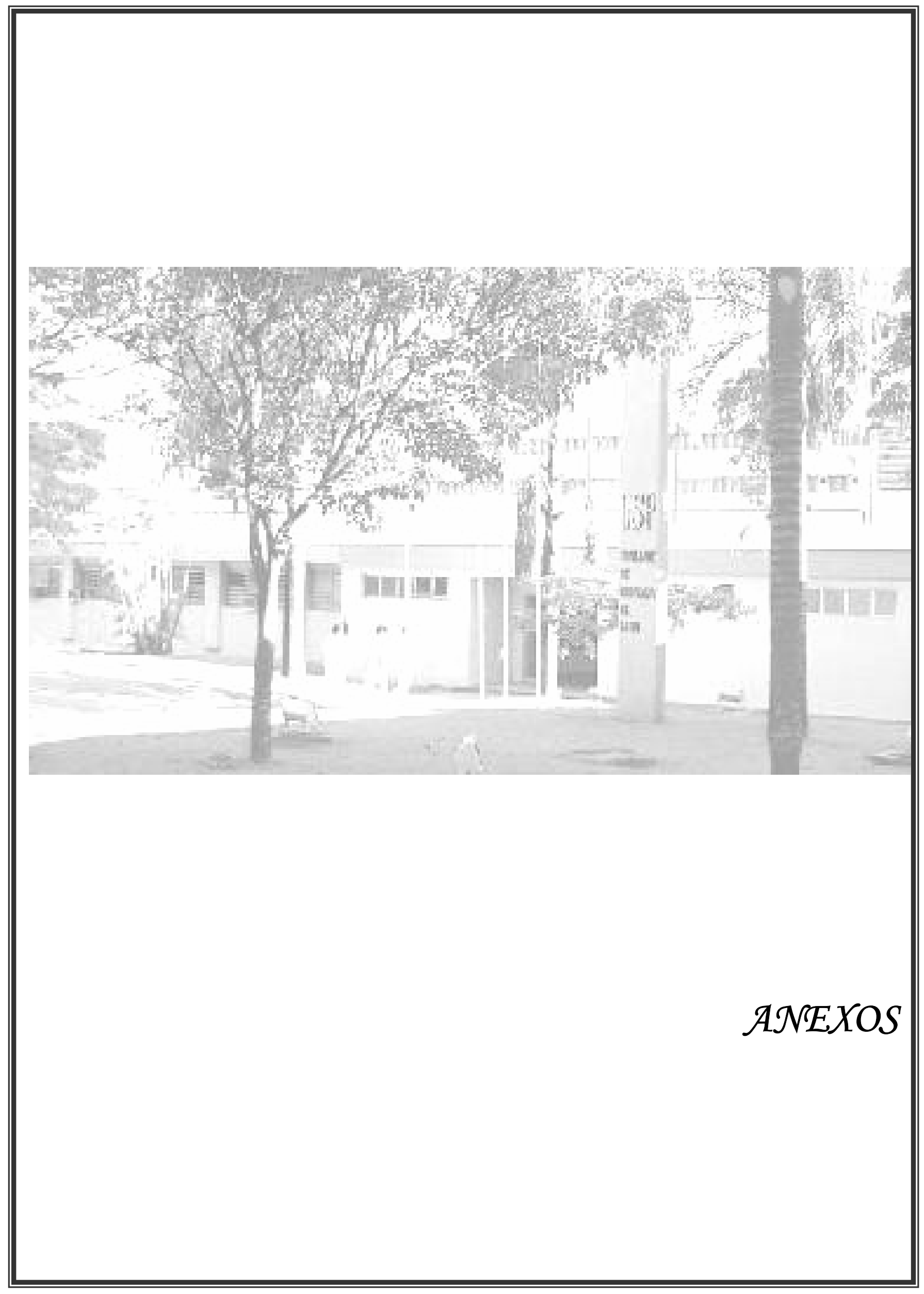


ANEXO 1 - Carta de aprovação do Comitê de ética e Pesquisa

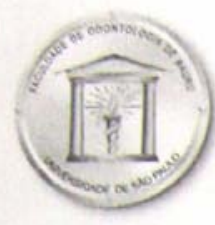

Bauru, 03 de abril de 2006.

\section{Processo $n^{\circ} 11 / 2006$}

Universidade de São Paulo Faculdade de Odontologia de Bauru

Al. Dr. Octávio Pinheiro Brisolla, 9-75 - Bauru-SP - CEP $17012-901$ - C.P 73 PABX (0XX14)3235-8000 - FAX (0XX14)3223-4679

Comifê de Ética em Pesquisa

Senhor Professor,

O projeto de pesquisa encaminhado a este Comitê de Ética em Pesquisa em Seres Humanos, denominado "Avaliação in vitro da capacidade de selamento coronário de três materiais usados como barreira provisória, em dentes tratados endodonticamente obturados com diferentes cimentos endodônticos, utilizando o método de filtraçăo de fluido", de autoria de Cristiane Machado de Almeida Nishiyama, que será desenvolvido sob sua orientaçāo, foi enviado ao relator para avaliação.

$\mathrm{Na}$ reunião de 29 de março de 2006 o parecer do relator. aprovando o projeto, foi aceito pelo Comitê, considerando que não existem infrações éticas pendentes.

Informamos que após o envio do trabalho concluido, este Comitê enviará o parecer final, que será utilizado para publicação do trabalho.

\section{Atenciosamente,}

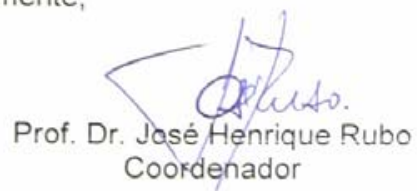

$11 m^{\circ}$ Sr. Prof. Dr. Paulo Amarante de Araújo

DD. Docente do Departamento de Dentistica, Endodontia e Materiais Dentários 
ANEXO 2 - Carta de Doação dos Dentes

\section{INSTRUMENTO DE DOAÇÃO DE DENTES}

\section{Identificação do Doador}

Nome

(legível)

Data de

Local: UF

$\mathrm{RG} \mathrm{n}^{\mathrm{o}}$. CPF $n^{0}$ :

Endereço $\mathrm{n}^{\mathrm{o}}$ :

Cidade UF CEP

Telefones para contato

e-mail

\section{DECLARAÇÃO}

Declaro ter sido esclarecido sobre quais os motivos que levaram a necessidade de remoção do(s) dente(s) (código) e concordo que os mesmos sejam utilizados para pesquisa "Avaliação in situ da desmineralização de esmalte humano em diferentes graus de maturação" desde que aprovada por um Comitê de Ética em Pesquisa em Seres Humanos.

Fui ainda esclarecido que minha identidade não será divulgada por qualquer meio e que o material recolhido será utilizado unicamente para pesquisa.

Bauru, de de 20 


\section{INSTRUMENTO DE DOAÇÃO DE DENTES}

\section{Identificação do Doador}

Nome (legível)

Data de Nascimento Local: UF RG $n^{\circ}$ : CPF $\mathrm{n}^{\mathrm{O}}$ :

Endereço $n^{0}:$

Cidade UF CEP

Telefones para contato e-mail

\section{DECLARAÇÃO}

Declaro ter sido esclarecido sobre quais os motivos que levaram a necessidade de remoção do(s) dente(s) (código) e concordo que os mesmos sejam utilizados para pesquisa "Avaliação in situ da desmineralização de esmalte humano em diferentes graus de maturação" desde que aprovada por um Comitê de Ética em Pesquisa em Seres Humanos.

Fui ainda esclarecido que minha identidade não será divulgada por qualquer meio e que o material recolhido será utilizado unicamente para pesquisa.

Bauru, de de 20 


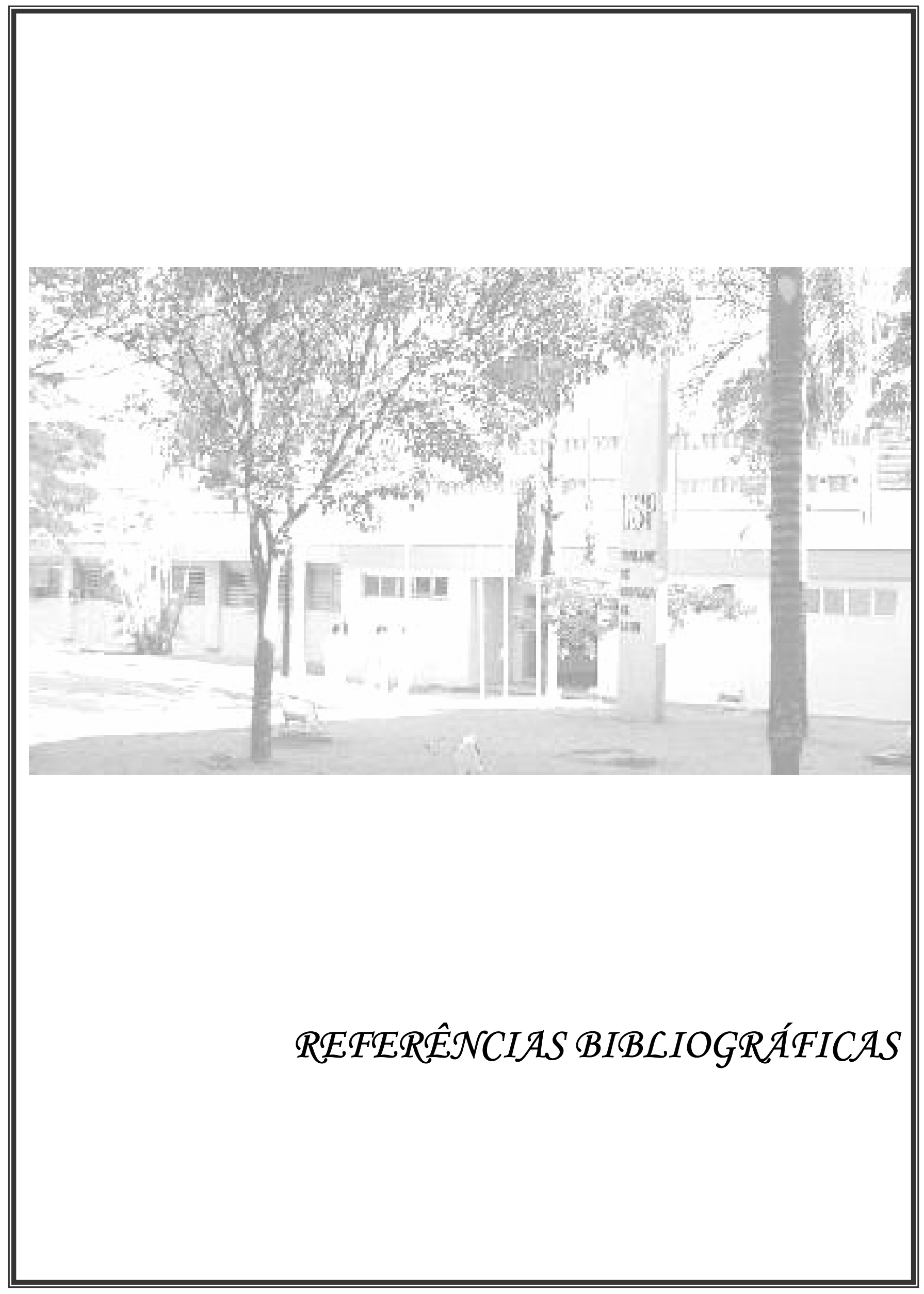




\section{REFERÊNCIAS BIBLIOGRÁFICAS:}

1-Anderson RW, Powel BJ, Pashley DH. Microleakage of three endodontic restaurations. J Endod. 1988 Oct ;14(10):497-501.

2-Anderson RW, Powel BJ, Pashley DH. Microleakage of temporary restorations in complex endodontic access preparations. J Endod. 1989 Nov;15(11):526-8.

3-Barthel CR, Zimmer S, Wussogk R, Roulet JF. Long-term bacterial leakage along obtured roots restored with temporary and adhesive fillings. Endod J. Sept 2006;27(9):559-562.

4-Belli S, Zhang Y, Pereira PNR, Pashley DH. Adhesive sealing of the pulp chamber. J. Endod. 2001 Aug;27(8):521-6.

5-Biggs SG, Knowles KI, Ibarrola JL, Pashley, DH. An in vitro assessment of the sealing ability of Resilon/Epiphany using fluid filtration. Endod J. 2006 Aug;32(8):759-61.

6-Blaney TD, Peters DD, Setterstrom J, Bernier WE. Marginal sealing quality of IRM ad Cavit as assessed by microbial penetration. Endod J.1981 Oct; 7(10):453-7.

7-Bobotis HG, Anderson RW, Pashley DH, Pantera EA. A microleakage study of temporary restorative materials used in endodontics. Endod J.1989 Dec;15(12):569-72.

8-Bouillaguett S, Troesch S, Wataha JC, Krejci I, Meyer J, Pashley DH. Microtensile bond strength between adhesive cements and root canal dentin. Dent Mater. 2003 Jan;19(1):199-205. 
9-Camps J, Pashley DH. Reliability of the dye penetration studies. Endod J. 2003 Sept;29(9):592-4.

10-Carvalho RM, Pereira JC, Yoshiyama M, Pashley DH. A review of polymerization contraction: the infleunce of stress development versus stress relief. Operative Dentistry.1996;21:17-24.

11-Chersoni S, Acquaviva GL, Prati C, Ferrari M, Grandini S, Pashley DH et al. In vivo fluid movement through dentin adhesives in endodontically treated teeth. J Dent Res. March 2005;84(3):223-7.

12-Chohayeb AA, Bassiouny MA. Sealing ability of intermediate restoratives used in endodontics. Endod J. 1985 June;11(6):241-44.

13-Çobankara FK, Adanir N, Belli S. Influence of smear layer on apical and coronal sealing ability of two sealers. Endod J. 2004 June;30(6):406-409.

14-Davalou S, Gutmann JL, Nunn MH. Assessment of apical and coronal root canal seals using contemporary endodontic obturation and restorative materials and techniques. Int Endod J. 1999;32:88-396.

15-Derkson GD, Pashley DH, Derkson ME. Microleakage measurements of selected restaurative materials: A new in vitro method. J Prosth Dent. 1986 Oct.; 56(4):435-40.

16-Ferracane JL. Materials in Dentristry. Principles and Aplications. 2th ed. Lippincott Willians \& Wilkins; 2001 p.23-5.

16-Galvan Junior RR, West LA, Liewehr FR, Pashley DH. Coronal microleakage of five materials used to created and intracoronal seal in endodontically tretaed teeth. J Endod. 2002 Feb;28(2):59-61.

17-García-Godoy $\mathrm{F}$ et al. Application of biologically-oriented dentin bonding principles to the use of endodontics irrigants. Am J Dent. 2005 Aug;18 
(4):281-90.

18-Gesi AG,Raffaelli O, Goracci C, Pashley DH, Tay FR, Ferrari M. Interfacial strength of Resilon and gutta-percha to intraradicular dentin. J Endod. 2005 Nov;31(11):809-813.

19-Gomes BPFA, Sato E, Ferraz CCR, Teixeira FB, Zaia AA, Souza-Filho FJ. Evaluation of time required for contamination $f$ coronally sealed canals medicated with calcium hydroxide and chlorhexidine. Int Endo J 2003;36: 604-9.

20-Grossman LI. Physical properties of root canal cements. J Endod. 1976;2 (6):166-75.

21-Guy $S$ et al. Periapical inflammation after coronal microbial inoculation of dog roots filled with gutta-percha or Resilon. Endod J. 2005 Feb;31(2):916.

22-Hommez GMG, Coppens CRM, De Moor RJG. Periapical health related to the quality of coronal restorations and root fillings. Int Endod J. 2002;35: 680-89.

23-Ingle JI. Root-canal obturation. J Amer Dent Ass. 1965;53(1):47-55.

24-Jenkins S, Kulild J, Williams K, Lyons W, Lee C. Sealing ability of three materials in the orifice of Systems Obturated with gutta-percha. Endod $\mathrm{J}$. 2006 March;32(3):225-7.

25-Leonardo MR, Leal JM. Endodontia - Tratamento dos Canais Radiculares. 3ํe. São Paulo;1998.

26-Lim CK. Microleakage of intermediate restorative materials. Endod J. 1990 March;16(3):116-8. 
27-Madison S, Wilcox LR. An evaluation of coronal microleakage in endodontically treated teeth: Part III - In vivo study. J Endod. 1987;13:569.

28-Magura ME, Kafrawy AH, Brown CE Jr, Newton CW. Human saliva coronal microleakage in obturade root canals: an in vitro study. J Endod. 1991 July;17(7):324-31.

29-Maloney SM, McClanaban SC, Goodell GG .The effect of thermocycling on a colored glass ionomer intracoronal barrier. J Endod. 2005;31(7):526528.

30-Marshall JF, Massler M. The sealing of pulpless teeth evaluated with radioisotopes. J Dent Med. 1961;16:172-84.

31-Miletic I, Anic I, Pezelj-Ribaric S, Jukic S. Laekage of five root canal sealears. Int Endod J. 1999 Sept; 32(5):415-8.

32-Nakabayashi N, Kojima K, Masahura E. The promotion of adhesion by the infiltration of monomers into tooth substrates. J Biomed Mater Res. 1982; 16:265-9.

33-Ozturk B, Ozer F, Belli S. An in vitro comparison of adhesive systems to seal pulp chamber walls. Int Endod J. 2004;37:297-306.

34-Pashley DH. Endodontics aplications of adhesive dentristry. Disponível em URL: http: www. rootsquestionsanswers. doc.

35-Pashley DH, Andringa HJ, Derkson GD, Derkson ME, Kalathoor SR. Regional variability in the permeability of human dentin. Arch Oral Biol. 1987;32:519-23.

36-Pashley EL, Tao L, Pashley DH. The sealing properties of temporary filling materials. J Prosth Dent. 1988; Sept 60 (3):292-6. 
37-Pisano DM, DiFiore PM, McClanahan SB, Lautenschlager EP, Duncan JL. Intraorifice sealing of gutta-percha obturated root canals to prevent coronal microleakage. Endod J. 1998 Oct; 24(10):659-662.

38-Pitout E, Oberholzer TG, Blingnault E, Molepo J. Coronal leakage of teeth root-filled with gutta-percha or Resilon root canal filling material. Endod J. 2006 Sept;32(9):879-81.

39-Pommel L, Camps J. Effects of pressure and measurement time on the fluid filtration method in endodontics. Endod J. 2001;April 27(4):256-8.

40-Ray HA, Trope M. Periapical status of endodontically treated teeth in relation to the technical quality of the root filling and coronal restaration. Int Endodd J. 1995;28:12-8.

41-Retief DH. Do adhesives prevent microleakage? Int Dent J. 1994;44:19-26.

42-Rich M, Glassman G. Bonded Endodontic Obturation. acesso em: july 2004 ; Disponível em URL htpp:/www. oralhealthjournal.com

43-Salehrabi R, Rotstein I. Endodontic treatment outcomes in a large patient population in the USA: An epidemiological study. Endod J. 2004 Dec;30(12):846-50.

44-Sauáia TS, Gomes BPFA, Pinheiro ET, Zaia AA, Ferraz CCR, Souza-Filho F. Microleakage evaluation of intraorifice sealing materials in endodontically treated teeth. Oral Surg Oral Med Oral Pathol Oral Radiol Endod. 2006 Aug;102(2):242-6.

45-Saunders WP, Saunders EM. Assessment of leakage in the restored pulp chamber of endodontically treated multirooted teeth. Int Endod J. 1990; 23:28-33. 
46-Saunders WP, Saunders EM. Coronal leakage as a cause of failure in root canal therapy: a rewiew. Endod Dent Traumatol. 1994 Jun;3:105-8.

47-Schwartz RS. Adhesive Dentistry and Endodontics. Part 2: Bonding in the root canal system - The promise and the Problems: A Review. Endodo J. 2006 Dec;32:1125-34.

48-Schwartz RS, Fransman R. Adhesive dentistry and endodontics: materials, clinical strategies and procedures for restoration of access cavities: a review. Endod J. 2005 March;31(3):151-65.

49-Shipper G, Dag Orstravik M, Teixeira FB, Trope M. An evaluation of microbial leakage in roots filled with a thermoplastic synthetic Polymerbased root canal filling material (Resilon). Endod J. 2004 May;30(5):342-7.

50-Stevens RW, Strother JM, McClanaban SB. Leakage and sealer penetration in smear-free dentin after a final rinse with 95\% ethanol. Endod J. 2006 Aug;32(8):785-8.

51-Swanson K, Madison S. An evaluation of coronal microleakage in endodontically treated teeth. Part I. Time periods. J. Endod. 1987 Feb; 13(2):56-9.

52-Swanson K, Madison S, Chiles SA. An evaluation of coronal microleakage in endodontically treated teeth. Part II. Sealer types. J. Endod. 1987 March ; 13(3):109-11.

53-Slutzky- Goldberg I, Weiss El, Matalon S. Antibacterial properties of filling materials. J Endod. 2006 March;32(3):214-17.

54-Souza FD, Pécora JD, Silva RG. The effect on coronal leakage of liquid adhesive application over root fillings after smear layer removal with EDTA or Er: YAG laser. Oral Surg Oral Med Oral Pathol Oral Radiol Endod. 2005; 99:125-8. 
55-Stratton RK, Apicella MJ, Mines P. A fluid filtration comparison of guta percha versus Resilon, a new soft resin endodontic obturation system. Endod J. 2006 July;32(7):642-5.

56-Tay FR et al. Effectiveness of resin-coated gutta-percha cones and a dualcured, hydrophilic methacrylate resin-based sealer in obturating root canals. Endod J. 2005 Sept;31(4):659-664.

57-Tay FR et al. Bondability of Resilon to a methacrylate-based root canal sealer. Endod J. Feb 2006;32(2):133-7.

58- Taylor MJ, Lynche E. Microleakage. J Dent. 1992 Feb;20(1):3-10.

59-Teixeira et al. Frature resistence of roots endodontically treated with a new resin filling material. J Am Dent Assoc. 2004;135:646-52.

60-Tewari S, Tewari S. Assesement of coronal microleakage in intermediately restored endodontic acess cavities. Oral Surg Oral Med Oral Pathol Oral Radiol Endod. 2002;93:716-9.

61-Torabinejad M, Walton RE. Princípios e Prática em Endodontia. $2^{\underline{0}} \mathrm{ed}$. Santos: Ed. Santos; 1997. p.239-241.

62-Torabinejad M, Ung B, Kettering JD. In vivo bacterial penetration of coronally unsealed endodontically treated teeth. Endod J Dec. 1990; 6(12):566-9.

63-Tronstad L, Asbjornsen K, Duving L, Pedersen I, Eriksen HM. Influence of coronal restorations on theperiapical health to endodontically treated 
teeth. Endod Dental Traumatol. 2000;16:218-21.

64-Tselnik M, Baumgartner JC, Marshall JG. Bacterial leakage with mineral trioxide aggregate or a resin-modified glass ionomer used as a coronal barrier. Endod J. 2004 Nov;30(11):782-84.

65-Tunga $U$, Bodrumlu E. Assessment of sealing ability of a new root canal obturation material. Endod J. 2006 Sept;32(9):876-8.

66-Turner JE, Anderson RW, Pashley DH, Pantera EA. Microleakage of temporary endodontic restorations in teeth restored with amalgam. Endod J. 1990 Jan;16(1):1-4.

67-Uranga A, Blum JY, Esber S, Parahy E, Prado C A. comparative study of four coronal obturation materials in Endodontic Treatment. J Endod. 1999; 25(3):178-80.

68-Vassiliadis L, Lialios E, Kouvas V, Economides N. Effect of smear layer on coronal microleakage. Oral Surg Oral Med Oral Patlthol Oral Radiol Endod. 1996;82:15-20.

69-Vire DE. Failures of endodontically treated teeth: classification and evaluation. J Endod. 1991;17:338-42.

70-Wells JD et al. Intracoronal sealing ability of two dental cements. J Endod. 2002 June;28(6):443-7.

71-Whitworth JM, Baco L. Coronal leakage of sealer-only backfill: an in vitro evaluation. Endod J. 2005 April;31(4):280-2.

72-Williams C, Loushine RJ, Weller N, Pashley DH, Tay FR. A comparison of cohesive strenght and siffness of Resilon and gutta-percha. Endod J. 2006 Jun;32(6):553-5. 
73-Wimonchit S, Timpawat S, Vongsavan N. A comparison of techniques for assessment of coronal dye leakage. J Endod. 2002 Jan;28(1):1-4.

74-Wolanek GA, Loushine RJ, Weller N, Kimbrough WF, Volkmann KR. In vitro bacterial penetration of endodontically treated teeth coronaly sealed with a dentin bonding agent. J Endod. 2001 May;27(5):354-7.

75-Wu MK, De Gee AJ, Wesselink PR, Moorer WR. Fluid transport and bacterial penetration root canal fillings. Int Endod J. 1993;26:203-8.

76-Wu MK, Fan B, Wesselink P R. Diminished leakage along root canals filled with gutta-percha without sealers over time: laboratory study. Int Endod J. 2000 Mar;33(2):121-5.

77-Wu MK, Wesselink PR. Endodontic leakage studies reconsidered. Part I. Metodology, application and relevance. Int Endod J. 1993 Jan;26(1):3743.

78-Yougson CC et al. A fluid filtration and clearing technique to asses microleakage associated with three dentin bonding systems. J Dent. 1999;22:222-233.

79-Zaia AA, Nakagawa R, De Quadros I, Gomes BPFA, Ferraz CCR, Teixeira FB, Souza-Filho FJ. An in vitro evaluation of four materials as barriers to corornal microleakage in root-filled teeth. Inter Endodon J. 2002;35:72934.

80-Zmener O, Banegas G, Pameijer $\mathrm{CH}$. Coronal microleakage of three temporary restorative materials: an in vitro study. Endodo J. 2004 Aug;30(8):582-4. 


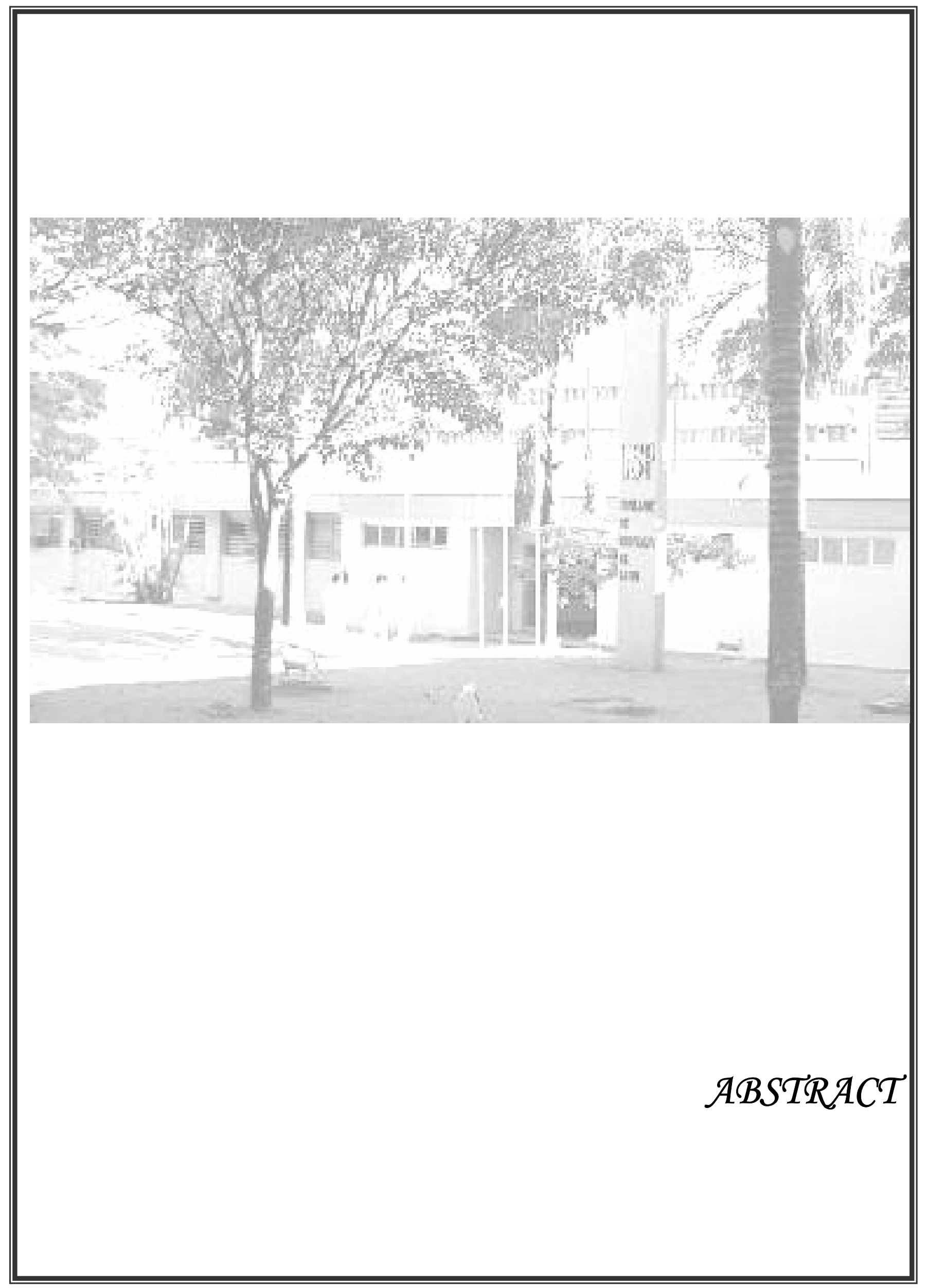




\section{ABSTRACT \\ In vitro fluid filtration evaluation of intracoronal sealing ability of three materials used as secondary barrier}

Great part of endodontic treatment fails because of failures in provisory or definitive restoration, permiting a coronal microleakage. For these reasons, in last years, there is a preocupation in sealing intra-coronal cavity after the treatment, to have in view a longer longevity. So many materials are being used for this purpose. Recently it has been developed by Pashley, D.H. and his collaborators, a so called "Fluid Transport method and capillary flow" by the method of fluid transport. This method was inicitially developed for measuring dentinal permeability and is now used for studying the microleakage of root filling materials throuhg seal of intra-coronal fillings. It is not a destructive and quantitative method that permits the observation of the same specimens in different periods of time. The aim of the present study is to evalute the fluid infiltration and permeability of intracoronal sealers, using two endodontics cements. 40 human teeth were divided into two grups. Group I, with 30 teeth, canals were filled with gutta-percha cones and AH Plus cement. Group II, with 10 teeth, canals were filled with Epiphany System. Four millimeters of the material was placed on the pulp chamber floor. Group I was divided in three groups: In Group IA, after canal filling, pulp chambers were filled with temporary filling IRM. In Group IB, pulp chambers were sealed with Socth Bond Multi Purpose Plus and Group IC, pulp chambers were sealed with Adper Singlebond. In Group II no sealing was made in pulp chambers of teeth. The fluid filtration for each group was compared by Kruskal-Wallis test. In the 15 days period, low filtration indexes had been observed in all groups, but Group IC presented the lowest level of filtration results. In the 30 days period, IA group behaved as expected, the IRM permiting the larger filtration. The groups IB, IC e II, perminting layer filtration than in the 15 days period. In the 60 days period, the group II presented higher level of filtration but the groups IB e IC presented the lost results of filtration, could being considered equally efficients, and the group IA demonstred the poorest results. In conclusion all groups showed filtration in 15, 30 and 60 days period.

Key words: fluid filtration, leakage, roort canal filling 